Wildlife Program

Prepared in cooperation with the U.S. Army Corps of Engineers

Least Bell's Vireos and Southwestern Willow Flycatchers at the San Luis Rey Flood Risk Management Project Area in San Diego County, California: Breeding Activities and Habitat Use-2020 Annual Report

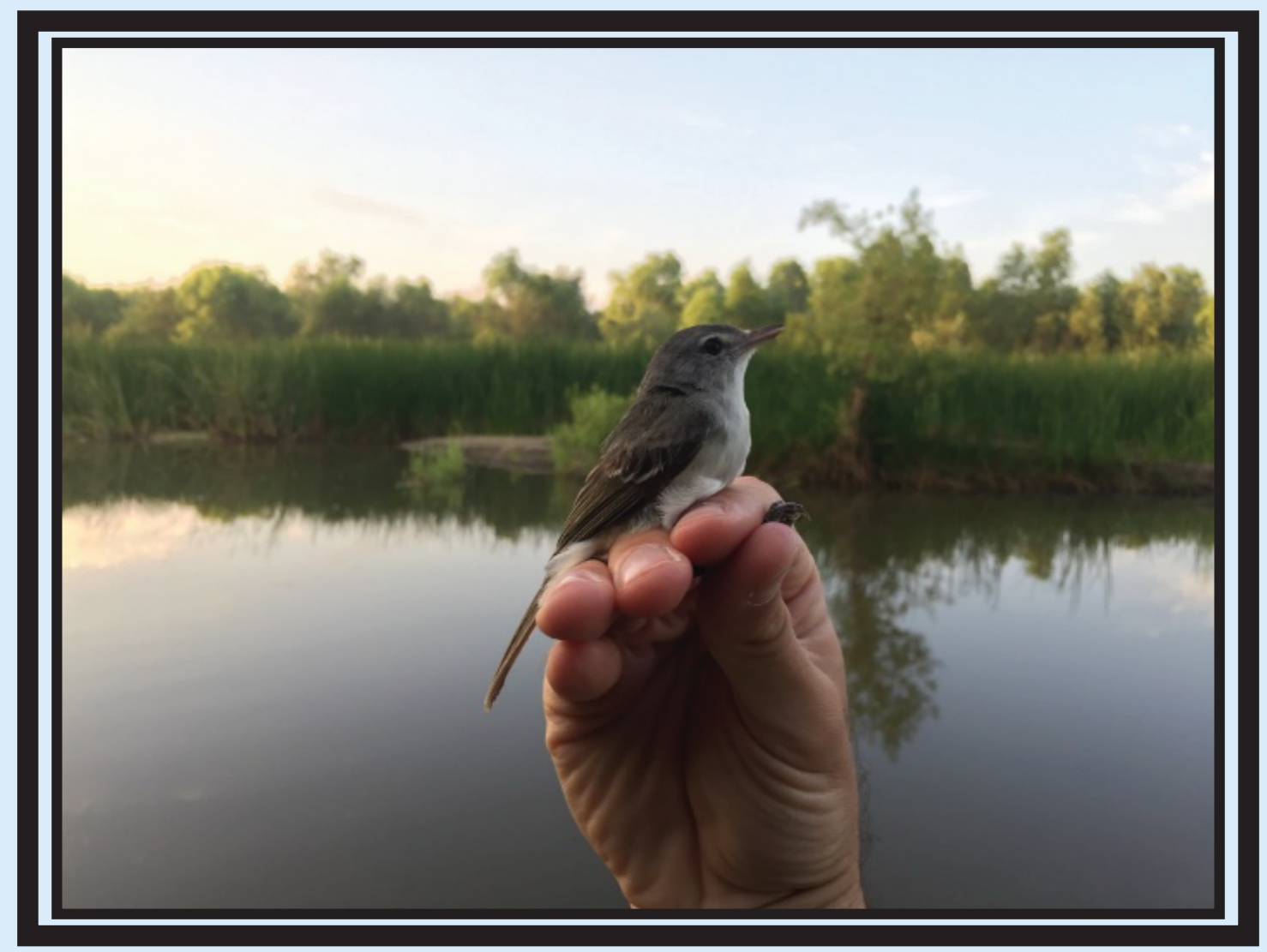

Open-File Report 2021-1053 
Cover: An adult male Least Bell's on the lower San Luis Rey after being color-banded. Photograph taken by Ryan Pottinger, U.S. Geological Survey, April 21, 2020. 


\section{Least Bell's Vireos and Southwestern Willow Flycatchers at the San Luis Rey Flood Risk Management Project Area in San Diego County, California: Breeding Activities and Habitat Use-2020 Annual Report}

By Alexandra Houston, Lisa D. Allen, Ryan E. Pottinger, and Barbara E. Kus

Wildlife Program

Prepared in cooperation with the U.S. Army Corps of Engineers

Open-File Report 2021-1053 


\section{U.S. Geological Survey, Reston, Virginia: 2021}

For more information on the USGS - the Federal source for science about the Earth, its natural and living resources, natural hazards, and the environment—visit https://www.usgs.gov or call 1-888-ASK-USGS.

For an overview of USGS information products, including maps, imagery, and publications, visit https://store.usgs.gov/.

Any use of trade, firm, or product names is for descriptive purposes only and does not imply endorsement by the U.S. Government.

Although this information product, for the most part, is in the public domain, it also may contain copyrighted materials as noted in the text. Permission to reproduce copyrighted items must be secured from the copyright owner.

Suggested citation:

Houston, A., Allen, L.D., Pottinger, R.E., and Kus, B.E., 2021, Least Bell's Vireos and Southwestern Willow Flycatchers at the San Luis Rey flood risk management project area in San Diego County, California-Breeding activities and habitat use—2020 annual report: U.S. Geological Survey Open-File Report 2021-1053, 67 p., https://doi.org/10.3133/ofr20211053.

ISSN 2331-1258 (online) 


\section{Contents}

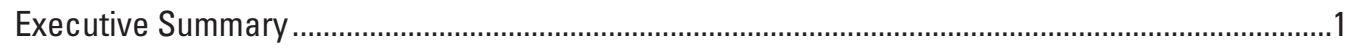

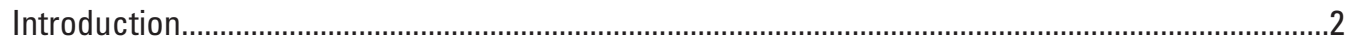

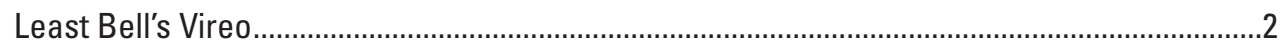

Southwestern Willow Flycatcher..........................................................................................

San Luis Rey Flood Risk Management Project Area .................................................................

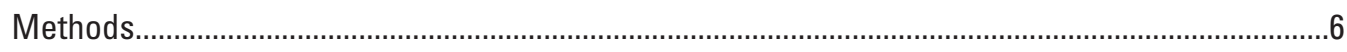

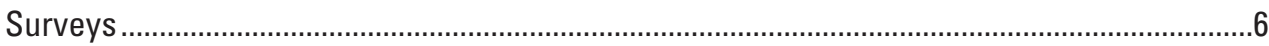

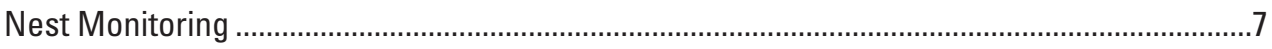

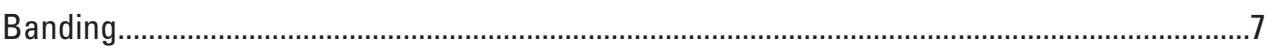

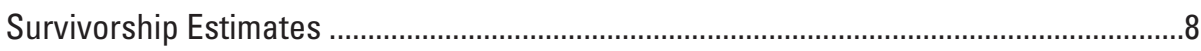

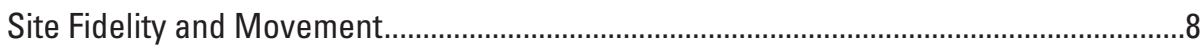

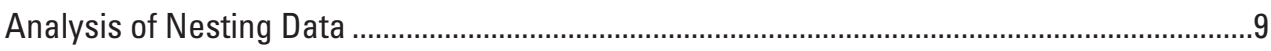

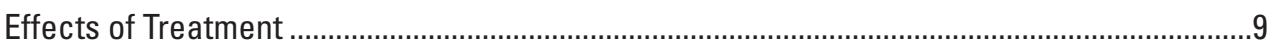

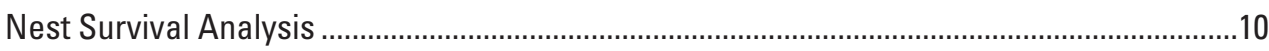

Vegetation Study Design ..................................................................................................

Vireo Habitat Use Study Design ....................................................................................12

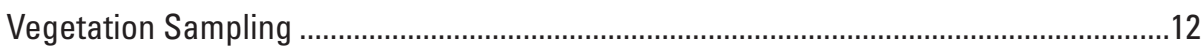

Vegetation Data Analysis .....................................................................................12

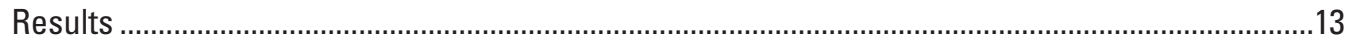

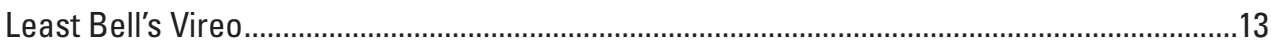

Population Size and Distribution ........................................................................... 13

Effects of Treatment on Habitat Use ...................................................................... 14

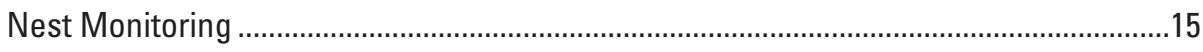

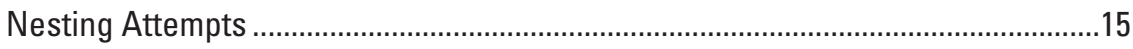

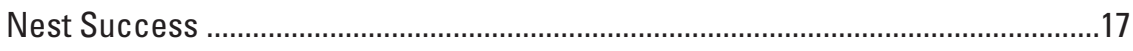

Brown-headed Cowbird Parasitism ...........................................................................18

Reproductive Success and Productivity..............................................................18

Effects of Treatment on Vireo Reproduction .............................................................20

Nest Survival and Habitat Use................................................................................

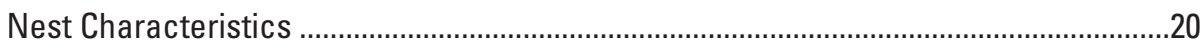

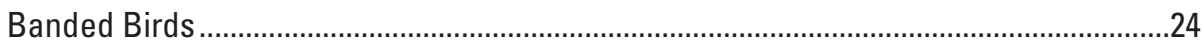

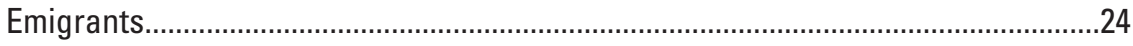

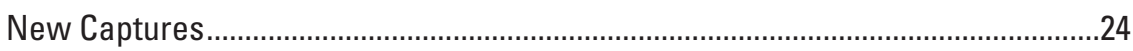

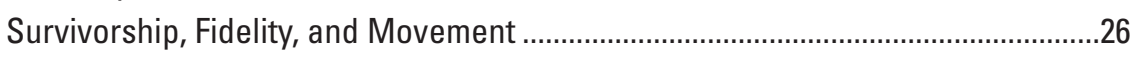

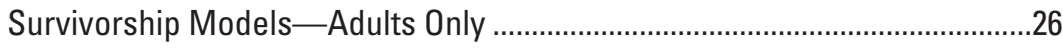

Survivorship Models_Adults versus First-Year Vireos..................................26

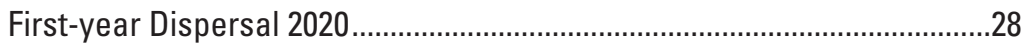

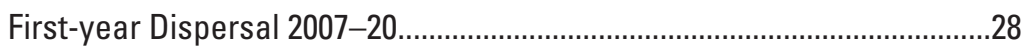

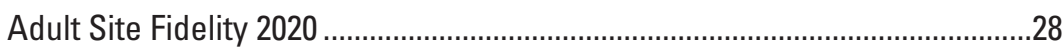

Effect of Treatment on Adult Site Fidelity ....................................................28

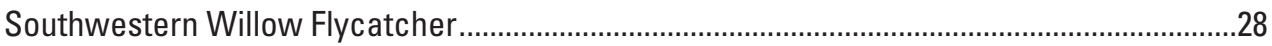

Population Size and Distribution ...................................................................................28 


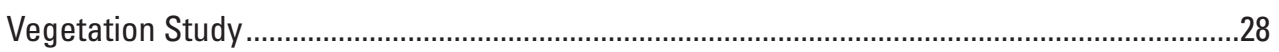

Vegetation Structure and Composition ........................................................................28

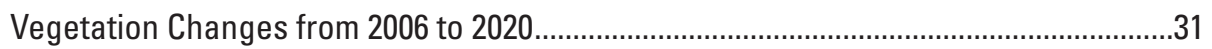

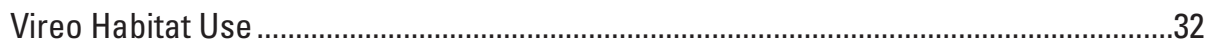

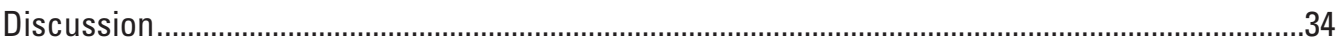

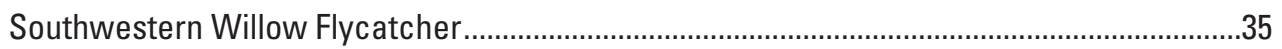

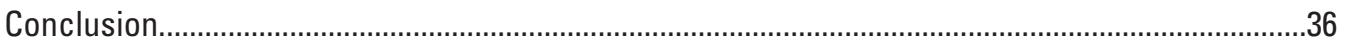

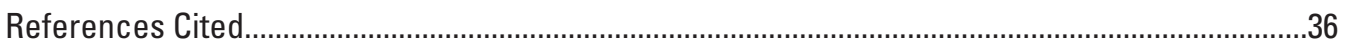

Appendix 1. Timeline and Description of Vegetation Treatments at the San Luis Rey

Flood Risk Management Project Area, California, 2005-20 ................................................38

Appendix 2. Locations of Least Bell's Vireo Territories and Completed Nests at the San

Luis Rey Flood Risk Management Project Area, California, 2020 .....................................42

Appendix 3. Status and Nesting Activities of Least Bell's Vireos at the San Luis Rey

Flood Risk Management Project Area, California, in 2020 ..................................................46

Appendix 4. Banded Adult Least Bell's Vireos at the San Luis Rey Flood Risk

Management Project Area, California, in 2020 ..............................................................51

Appendix 5. Between-year Movement of Emigrant Least Bell's Vireos from the San Luis

Rey Flood Risk Management Project Area to Other Areas Outside of the Project

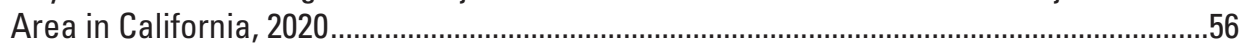

Appendix 6. Between-year Movement of Least Bell's Vireos banded as Juveniles in

2019 at the San Luis Flood Risk Program Area; redetected in 2020

Appendix 7. Between-year Movement of Adult Least Bell's Vireos at the San Luis Rey

Flood Risk Management Project Area, 2020 .........................................................................58

Appendix 8. Locations of Vegetation Transects, Nest-Centered Vegetation Plots, and

Vegetation Treatments at the San Luis Rey Flood Risk Management Project

Area, 2020

Appendix 9. Global Positioning System Coordinates (Decimal Degrees; World

Geographic System of 1984) for the Start and End Points (Quadrat) of Each

Vegetation Transect Sampled at the San Luis Rey Flood Risk Management

Project Area in 2006-20

\section{Figures}

1. Map showing Least Bell's Vireo and Southwestern Willow Flycatcher survey and monitoring sites at the San Luis Rey Flood Risk Management Project Area, California, in 2020 .....

2. Schematic showing Least Bell's Vireo territory boundary with two treatments and a section of overlap between the two treatments 10

3. Schematic showing vegetation transects in the Channel at the San Luis Rey Flood Risk Management Project Area, California, in 2020

4. Schematic showing nest-centered and territory vegetation plots sampled at the San Luis Rey Flood Risk Management Project Area, California, in 2020

5. Graph showing number of Least Bell's Vireo territories from 1984 to 2020 at the San Luis Rey Flood Risk Management Project Area, California

6. Graph showing number of first Least Bell's Vireo nests initiated by week at the San Luis Rey Flood Risk Management Project Area, California, 2020.

7. Graph showing nest initiation of first nests at the San Luis Rey Flood Risk Management Project Area, California, from 2006 to 2020. 
8. Graph showing average number of fledglings per pair by year at the San Luis Rey Flood Risk Management Project Area, California, from 2006 to 2020.

9. Graph showing number of monitored vireo territories by Treatment Index within the Channel at the San Luis Rey Flood Risk Management Project Area, California, 2020

10. Graphs showing the effect of Treatment Index on Least Bell's Vireo reproductive parameters at the San Luis Rey Flood Risk Management Project Area, California, 2020 .

11. Graph showing average percent foliage cover by height class at the San Luis Rey Flood Risk Management Project Area, California, in 2020.

12. Graph showing percent of total cover by vegetation type at Channel, Upper Pond, and Whelan Restoration sites at the San Luis Rey Flood Risk Management Project Area, California, in 2020

13. Graph showing average percent foliage cover by height class for the Channel at the San Luis Rey Flood Risk Management Project Area from 2006 to 2020

14. Graph showing average percent foliage cover by height class for Upper Pond at the San Luis Rey Flood Risk Management Project Area from 2006 to 2020

15. Graph showing average percent foliage cover by height class for Whelan Restoration and Whelan Mitigation at the San Luis Rey Flood Risk Management Project Area from 2006 to 2020

16. Graphs showing average percent foliage cover for territory plots compared to vegetation transects and nest plots compared to territory plots by height class in the Channel at the San Luis Rey Flood Risk Management Project Area, California, in 2020

17. Graphs showing average percent foliage cover for territory plots compared to vegetation transects and nest plots compared to territory plots by height class in the Upper Pond at the San Luis Rey Flood Risk Management Project Area, California, in 2020

\section{Tables}

1. Least Bell's Vireo and Southwestern Willow Flycatcher survey sites at the San Luis Rey Flood Risk Management Project Area, California, in 2020 ..

2. Site attributes of the Channel, Off-channel and Restoration monitoring sites at the San Luis Rey Flood Risk Management Project Area, California, in 2020.

3. Number and breeding status of Least Bell's Vireos at the San Luis Rey Flood Risk Management Project Area, California, in 2020.

4. Number and distribution of Least Bell's Vireo territories at the San Luis Rey Flood Risk Management Project Area, California, in 2006-20.

5. Number of Least Bell's Vireo territories and nests monitored at the San Luis Rey Flood Risk Management Project Area, California, in 2020.

6. Fate of Least Bell's Vireo nests at the San Luis Rey Flood Risk Management Project Area, California, in 2020

7. Reproductive parameters for nesting Least Bell's Vireos at the San Luis Rey Flood Risk Management Project Area, California, in 2020

8. Productivity per pair for nesting Least Bell's Vireos at the San Luis Rey Flood Risk Management Project Area, California, in 2020. Standard deviations presented with means 
9. Generalized linear model results, parameter estimate, standard error, $Z$ statistic and $P$-values for Least Bell's Vireo reproductive parameters per pair as a function of Treatment Index within the Channel at the San Luis Rey Flood Risk Management Project Area, California, 2020.

10. Logistic regression models for the effects of Treatment Index on daily nest survival of Least Bell's Vireos at the San Luis Rey Flood Risk Management Project Area, California, 2020

11. Logistic regression models for the effects of habitat structure on daily nest survival of Least Bell's Vireos at the San Luis Rey Flood Risk Project Area, California, from 2006 to 2020

12. Parameter estimate, standard error, odds ratios and 95-percent confidence intervals for models explaining the effect of habitat structure on the daily survival rate of Least Bell's Vireos at the San Luis Rey Flood Risk Management Project Area, California, from 2006 to 2020.

13. Least Bell's Vireo nest characteristics and results of Kruskal-Wallis and Mann-Whitney U-tests comparing Channel, Off-channel, and Restoration nests, and successful versus failed nests, at the San Luis Rey Flood Risk Management Project Area, California, in 2020

14. Host plant species used by Least Bell's Vireos at the San Luis Rey Flood Risk Management Project Area, California, in 2020

15. Banding status of Least Bell's Vireos detected at the San Luis Rey Flood Risk Management Project Area, California, in 2020, and those that emigrated from the Project Area in 2020...

16. Number of banded adult Least Bell's Vireos, by original year banded, age, and sex, at the San Luis Rey Flood Risk Management Project Area, California, in 2020 .......25

17. Number of emigrant Least Bell's Vireos detected outside of the Project Area that originated in the San Luis Rey Flood Risk Management Project Area, California, by original year banded, age, 2020 location, and sex

18. Total number of new Least Bell's Vireos captured and banded at the San Luis Rey Flood Risk Management Project Area, California, in 2020

19. Survivorship models for the effects of sex, year, and precipitation on adult survival for Least Bell's Vireos at the San Luis Rey Flood Risk Project Area, California, from 2006 to 2020

20. Parameter estimate, standard error, odds ratios and 95-percent confidence intervals for the top model explaining over-winter survivorship of adult Least Bell's Vireos at the San Luis Rey Flood Risk Project Area, California, from 2006 to 2020

21. Over-winter survivorship for adult female and adult male Least Bell's Vireos at the San Luis Rey Flood Risk Project Area, California, from 2006 to 2020.

22. Survivorship models for the effect of age, year and precipitation on survival and the effect of year on detection probability of Least Bell's Vireos at the San Luis Rey Flood Risk Project Area, California, from 2006 to 2020

23. Parameter estimate, standard error, odds ratios and 95-percent confidence intervals for the top model explaining over-winter survivorship of first-year versus adult Least Bell's Vireos at the San Luis Rey Flood Risk Project Area, California, from 2006 to 2020

24. Over-winter survivorship and detection probabilities for adult and first-year Least Bell's Vireos at the San Luis Rey Flood Risk Project Area, California, from 2006 to 2020 
25. Number of first-year Least Bell's Vireos that originated at the San Luis Rey Flood Risk Management Project Area and returned to the Project Area or returned to areas outside of the Project Area from 2007 to 2020, by year and sex.........29

26. Generalized linear model results, parameter estimate, standard error, $t$ statistic and $P$-values for banded Least Bell's Vireo movement as a function of the expected Treatment Index for 2019 territories at the San Luis Rey Flood Risk Management Project Area, California, 2020

27. Number of vegetation transects and sampling points at the San Luis Rey Flood Risk Management Project Area, California, in 2020

\section{Conversion Factors}

International System of Units to U.S. customary units

\begin{tabular}{|c|c|c|}
\hline Multiply & By & To obtain \\
\hline \multicolumn{3}{|c|}{ Length } \\
\hline centimeter $(\mathrm{cm})$ & 0.394 & inch (in) \\
\hline meter $(\mathrm{m})$ & 3.281 & foot $(\mathrm{ft})$ \\
\hline kilometer $(\mathrm{km})$ & 0.621 & mile (mi) \\
\hline \multicolumn{3}{|c|}{ Area } \\
\hline hectare (ha) & 2.471 & acre \\
\hline \multicolumn{3}{|c|}{ Flow } \\
\hline cubic meter per second $\left(\mathrm{m}^{3} / \mathrm{s}\right)$ & 35.315 & cubic feet per second $\left(\mathrm{ft}^{3} / \mathrm{s}\right)$ \\
\hline
\end{tabular}

Temperature in degrees Fahrenheit $\left({ }^{\circ} \mathrm{F}\right)$ may be converted to degrees Celsius $\left({ }^{\circ} \mathrm{C}\right)$ as follows: ${ }^{\circ} \mathrm{C}=\left({ }^{\circ} \mathrm{F}-32\right) / 1.8$.

\section{Datum}

Horizontal coordinate information is referenced to the World Geographic System 1984 (WGS 84). 


\section{Abbreviations}

$\begin{array}{ll}\text { AIC } & \text { Akaike's Information Criterion } \\ \text { DSR } & \text { daily survival rate } \\ \text { GLM } & \text { Generalized Linear Model } \\ \text { GPS } & \text { Global Positioning System } \\ \text { MCBCP } & \text { Marine Corps Base Camp Pendleton } \\ \text { NOAA } & \text { National Oceanographic and Atmospheric Administration } \\ \text { USFWS } & \text { U.S. Fish and Wildlife Service } \\ \text { USGS } & \text { U.S. Geological Survey }\end{array}$




\title{
Least Bell's Vireos and Southwestern Willow Flycatchers at the San Luis Rey Flood Risk Management Project Area in San Diego County, California: Breeding Activities and Habitat Use-2020 Annual Report
}

\author{
By Alexandra Houston, Lisa D. Allen, Ryan E. Pottinger, and Barbara E. Kus
}

\section{Executive Summary}

Surveys and monitoring for the endangered Least Bell's Vireo (Vireo bellii pusillus; vireo) were done at the San Luis Rey Flood Risk Management Project Area (Project Area) in the city of Oceanside, San Diego County, California, between March 31 and July 20, 2020. We completed four protocol surveys during the breeding season, supplemented by weekly territory monitoring visits. We identified a total of 161 territorial male vireos; 145 were confirmed as paired and 4 were confirmed as single males. For the remaining 12 territories, we were unable to confirm pair status. Three transient vireos were detected in 2020. The vireo population in the Project Area increased by 26 percent from 2019 to 2020. Vireo populations increased across San Diego County, with a 39-percent increase documented at Marine Corps Base Camp Pendleton (MCBCP); a 58-percent increase at Marine Corps Air Station; a 78-percent increase on the Otay River; and a 7-percent increase in the population on the middle San Luis Rey River.

We used an index of treatment (Treatment Index) to evaluate the impact of on-going vegetation clearing on the Project Area vireo population. The Treatment Index measures the cumulative effect of vegetation treatment within a territory (since 2005) by using the percent area treated weighted by the number of years since treatment. We found that the Treatment Index for unoccupied habitat was more than five times that of occupied habitat, indicating that vireos selected less disturbed habitat in which to settle.

We monitored vireo nests at three general site types: (1) within the flood channel where exotic and native vegetation removal has occurred regularly (Channel), (2) three sites next to the flood channel where limited exotic and native vegetation removal has occurred (Off-channel), and (3) three sites that have been actively restored by planting native vegetation (Restoration). Nesting activity was monitored in 100 territories, 4 of which were occupied by single males. Hatching success was higher in the Channel relative to the Off-channel. We found no other differences between Channel, Off-channel, and Restoration nests in terms of clutch size or fledging success. There also was no difference in measures of productivity per pair between Channel, Off-channel, Restoration, and Mixed territories (territories that were classified as one site type but nesting occurred in another site type, or where multiple site types were used for nesting). Overall, breeding success and productivity were lower in 2020 than in 2019, with 69 percent of pairs fledgling at least one young and pairs fledging an average of $2.1 \pm 1.7$ young.

To investigate whether the cumulative years of treatment had an impact on vireo reproductive effort, we looked at the effects of the Treatment Index on reproductive parameters. Results from generalized linear models indicated that treatment did not have an effect on vireo nesting effort or the number of vireo fledglings per pair produced in 2020.

Similarly, our analysis of nest survival for 2020 revealed no effect of Treatment Index on daily survival rate. Analysis of vegetation data collected at vireo nests from 2006 to 2020 revealed that vegetation at $1-2$ meters $(\mathrm{m})$ from the ground was the most important predictor of daily survival rate.

There were differences in nest-placement characteristics among site types and successful/unsuccessful nests. Channel nests were placed higher in the vegetation than Off-channel or Restoration nests. Host plant height, distance to edge of host plant, and distance to edge of vegetation clump were greater at Channel sites compared with Off-channel sites, but were not different from Restoration sites. Within sites, we found only one difference between successful and unsuccessful nests. At Off-channel sites, successful nests were placed higher in the vegetation than unsuccessful nests.

Red/arroyo willow (Salix laevigata or Salix lasiolepis) and mule fat (Baccharis salicifolia) were the species most commonly selected for nesting by vireos in all 3 site types. Vireos used a wider variety of species for nesting in Channel and Off-channel sites (7 and 10 species, respectively) compared to Restoration sites (3 species).

Ninety-three vireos banded before the 2020 breeding season were resighted and identified at the Project Area in 2020, all of which were originally banded at the Project Area. Adult birds of known age ranged from 1 to 9 years old. 
A total of 171 vireos were newly banded in 2020 .

Twenty-eight adult vireos were banded with a unique color combination, and 143 nestlings were banded with a single dark blue numbered federal band on the left leg. Between 2006 and 2020 , survivorship of males ( $67 \pm 10$ percent) was consistently higher than females ( $59 \pm 11$ percent). First-year birds from 2006 to 2020 had an average over-winter survivorship of $17 \pm 5$ percent.

First-year dispersal in 2020 averaged $2.9 \pm 2.9$ kilometers $(\mathrm{km})$, with the longest dispersal $(13.5 \mathrm{~km})$ by a female that was recaptured at Las Flores Creek, MCBCP. From 2007 to 2012, most returning first-year vireos returned to the Project Area, whereas from 2013 to 2017, the majority of returning birds dispersed to areas outside of the Project Area. In 2018, the trend shifted, and most first-year vireos returned to the Project area. This trend continued in 2020 with most first-year vireos returning to the Project Area; 77 percent of all re-encountered first-year birds returned to the Project Area and 23 percent dispersed to areas outside of the Project Area (upstream to the middle San Luis Rey River and to drainages on $\mathrm{MCBCP}$ ).

Most of the returning adult male vireos showed strong between-year site fidelity to their previous territories. Eighty percent of males (45/56) occupied a territory in 2020 that they had defended in 2019 (within $100 \mathrm{~m}$ ). Thirty-three percent of females (2/6) detected in 2020 returned to a territory that they occupied in 2019. The average between-year movement for returning adult vireos was $0.1 \pm 0.5 \mathrm{~km}$.

We completed four protocol surveys for the endangered Southwestern Willow Fycatcher (Empidonax traillii extimus; flycatcher) at the Project Area between May 20 and July 20, 2020. No Willow Flycatchers were detected in the Project Area in 2020.

A total of 46 vegetation transects (526 points) were sampled at the San Luis Rey Flood Risk Management Project Area in 2020. Seventy-one percent (376/526) of points were in the Channel and 22 percent $(115 / 526)$ were at Upper Pond. The remaining 7 percent $(35 / 526)$ were at the Whelan Restoration site. Foliage cover below $1 \mathrm{~m}$ was higher at the Channel points compared to Upper Pond and Whelan Restoration. Higher foliage cover in the Channel was attributed to the higher herbaceous component. However, foliage cover from 1 to $3 \mathrm{~m}$ was higher at the Whelan Restoration site compared to both Upper Pond and the Channel. Average canopy height was similar at all three site types and was $4.4 \mathrm{~m}$ or less. From 2006 to 2020, total foliage cover declined above $1 \mathrm{~m}$ in the Channel, from 4 to $5 \mathrm{~m}$ at Upper Pond, and above $8 \mathrm{~m}$ at Whelan Restoration. Within the Channel, the steepest declines occurred between 2009 and 2013 and between 2014 and 2016. Since 2016, we observed an increase in percent foliage between 0 and $2 \mathrm{~m}$ within the Channel, but for other height classes, percent cover remained below levels detected before 2009. Changes in cover at Upper Pond and Whelan Restoration appeared to be driven by the loss of tall tree cover. The vegetation mowing and treatment activities, in combination with lack of precipitation (especially between 2012 and 2016), may have contributed to the decline in foliage cover observed from 2006 to 2020.

We sampled vegetation at 49 vireo nests and 49 random plots ("territory" plots) within territories in the Channel and Upper Pond following the 2020 breeding season. Vireos in the Channel selected territories with significantly more foliage cover above $2 \mathrm{~m}$ but less cover below $1 \mathrm{~m}$ relative to the available habitat. In contrast, Channel vireos selected nest sites within their territories with lower foliage cover above $3 \mathrm{~m}$ and were non-selective with regard to cover below $2 \mathrm{~m}$. Vireos at Upper Pond generally were less selective with regard to territory and nest sites but tended to select territories with more foliage cover from 1 to $2 \mathrm{~m}$ and above $8 \mathrm{~m}$, and they selected nest sites within their territories with greater foliage cover from 0 to $1 \mathrm{~m}$.

\section{Introduction}

This work was done in collaboration with the U.S. Army Corps of Engineers, Los Angeles District.

\section{Least Bell's Vireo}

The Least Bell's Vireo (Vireo bellii pusillus; vireo) is a small, migratory, songbird that breeds in southern California and northwestern Baja California, Mexico, from April through July. Historically abundant within lowland riparian ecosystems, vireo populations began declining in the late 1900s as a result of habitat loss and alteration associated with urbanization and conversion of land adjacent to rivers to agriculture (Franzreb, 1989; U.S. Fish and Wildlife Service, 1998; Riparian Habitat Joint Venture, 2004). Additional factors contributing to the vireo's decline have been the expansion in range of the brood-parasitic Brown-headed Cowbird (Molothrus ater; cowbird), to include the Pacific Coast (U.S. Fish and Wildlife Service, 1986; Franzreb, 1989; Kus, 1998, 1999; Kus and others, 2010), and the introduction of invasive exotic plant species such as giant reed (Arundo donax) into riparian systems. By 1986, the vireo population in California numbered just 300 territorial males (U.S. Fish and Wildlife Service, 1986).

In response to the dramatic reduction in numbers of vireos in California, the California Fish and Game Commission listed the species as endangered in 1980, with the U.S. Fish and Wildlife Service (USFWS) following suit in 1986. Since listing, the vireo population in southern California has rebounded, largely in response to cowbird control and habitat restorationandpreservation(Kus, 1999; KusandWhitfield,2005). As of 2006, the statewide vireo population was estimated to be approximately 2,500-3,000 territories (U.S. Fish and Wildlife Service, 2006a), of which approximately 10 percent occurred along the San Luis Rey River between Interstate 15 and Interstate 5 . 
Male vireos arrive on breeding grounds in southern California in mid-March. Male vireos are vocally conspicuous and frequently sing their diagnostic primary song from exposed perches throughout the breeding season. Females arrive approximately 1-2 weeks after males and are more secretive. They often are seen early in the season traveling through habitat with the male. The female, with the male's help, builds an open cup nest in dense vegetation approximately 1 meter $(\mathrm{m})$ above the ground. Clutch size for vireos averages three to four eggs. Typically, the female and male incubate the eggs for 14 days and young fledge from the nest at 11-12 days of age. It is not unusual for vireos to re-nest after a failed attempt provided ample time remains within the breeding season. Vireos rarely fledge more than one brood in a season, although double-brooding can be more common during years when breeding conditions are favorable (early initiation, high early fledging success; Ferree and Kus, unpub. data, 2008b; Houston and others, unpub. data, 2017, 2019). Nesting lasts from early April through July, but adults and juvenile birds remain on the breeding grounds into late September through early October before migrating to their wintering grounds in southern Baja California, Mexico (Kus and others, 2010).

\section{Southwestern Willow Flycatcher}

The Southwestern Willow Flycatcher

(Empidonax traillii extimus; flycatcher) is one of four subspecies of Willow Flycatcher in the United States, with a breeding range including southern California, Arizona, New Mexico, extreme southern portions of Nevada and Utah, and western Texas (Hubbard, 1987; Unitt, 1987). Restricted to riparian habitat for breeding, the flycatcher has declined in recent decades in response to widespread habitat loss throughout its range and, possibly, cowbird parasitism (Wheelock, 1912; Willett, 1933; Grinnell and Miller, 1944; Remsen, 1978; Garrett and Dunn, 1981; Unitt, 1984, 1987; Gaines, 1988; Schlorff, 1990; Whitfield and Sogge, 1999; Kus and Whitfield, 2005). By 1993, the species was believed to number approximately 70 pairs in California (U.S. Fish and Wildlife Service, 1993) in small, disjunct populations. The flycatcher was listed as endangered by the state of California in 1992 and by the USFWS in 1995.

Willow Flycatchers in southern California co-occur with the vireo. However, unlike the vireo, which has increased tenfold since the mid-1980s in response to management efforts, Willow Flycatcher numbers have remained low. Currently, most flycatchers in California are concentrated in two sites: the Owens River Valley in Inyo County (L. Greene, California Department of Fish and Wildlife, written commun., 2015) and the upper San Luis Rey River, including part of the Cleveland National Forest in San Diego County (S.L. Howell, U.S. Geological Survey, unpub. data, 2019). Outside of these sites, flycatchers occur as small, isolated populations of one to six pairs (Kus and others, 2003).
Male flycatchers typically arrive in southern California at the end of April, whereas females arrive approximately 1 week later. While on the breeding grounds, males sing repeatedly from exposed perches. Once the pair bond is established, the female builds an open-cup nest that usually is placed in a branch fork of a willow (Salix spp.) or plant with a similar branching structure approximately 1-3 $\mathrm{m}$ above the ground. The typical clutch of three to four eggs is laid in May-June. Females incubate for approximately 12 days and nestlings fledge within 12-15 days, in early July. Adults usually depart from their breeding territory in mid-August/early September to their wintering grounds in central Mexico and northern South America (U.S. Fish and Wildlife Service, 2002).

\section{San Luis Rey Flood Risk Management Project Area}

The San Luis Rey Flood Risk Management Project Area (Project Area) spans approximately 233 hectares (ha; 576 acres) of the lower San Luis Rey River in northwestern San Diego County, California (fig. 1; table 1). Authorized in 1970 and constructed during the late 1980s and early 1990s, the flood control Project Area includes single- and double-levee reaches and six off-channel detention ponds, five of which also serve as mitigation sites for impacts to biological resources within the channel. Operation and maintenance of the flood control project includes periodic vegetation clearing, exotic plant removal, and sediment removal to ensure that sufficient water conveyance capacity is maintained (U.S. Fish and Wildlife Service, 2006b). Management of the off-channel ponds involves adaptive habitat management such as vegetation clearing, exotic plant removal, and planting native vegetation.

Riparian vegetation communities at the Project Area include willow-dominated riparian, mixed mule fat (Baccharis salicifolia) and sandbar willow (Salix exigua) riparian scrub, freshwater marsh, and areas dominated by non-native giant reed. Dominant plants include red/arroyo willow (Salix laevigata/ Salix lasiolepis; we did not distinguish between these species), black willow (Salix gooddingii), Fremont cottonwood (Populus fremontii), sandbar willow, mule fat, and giant reed. Neighboring habitat and land-use types include coastal sage scrub, non-native grassland, and urban housing and commercial developments. Human disturbances such as homeless camps, recreation, illegal dumping, introduction of invasive exotic plants and feral animals, and use by pets from neighboring houses are pervasive throughout the Project Area (table 2).

The Project Area includes a channelized 10.7-kilometer (km; 6.6-mile) section of the lower San Luis Rey River from Interstate 5 to College Boulevard and six detention ponds outside of the channel in Oceanside, California (table 1). The Project Area is divided into 12 survey sites, 5 of which are primarily within the flood control channel (hereafter "Channel") and 7 that are outside of the channel (hereafter "Off-channel"; table 1). 


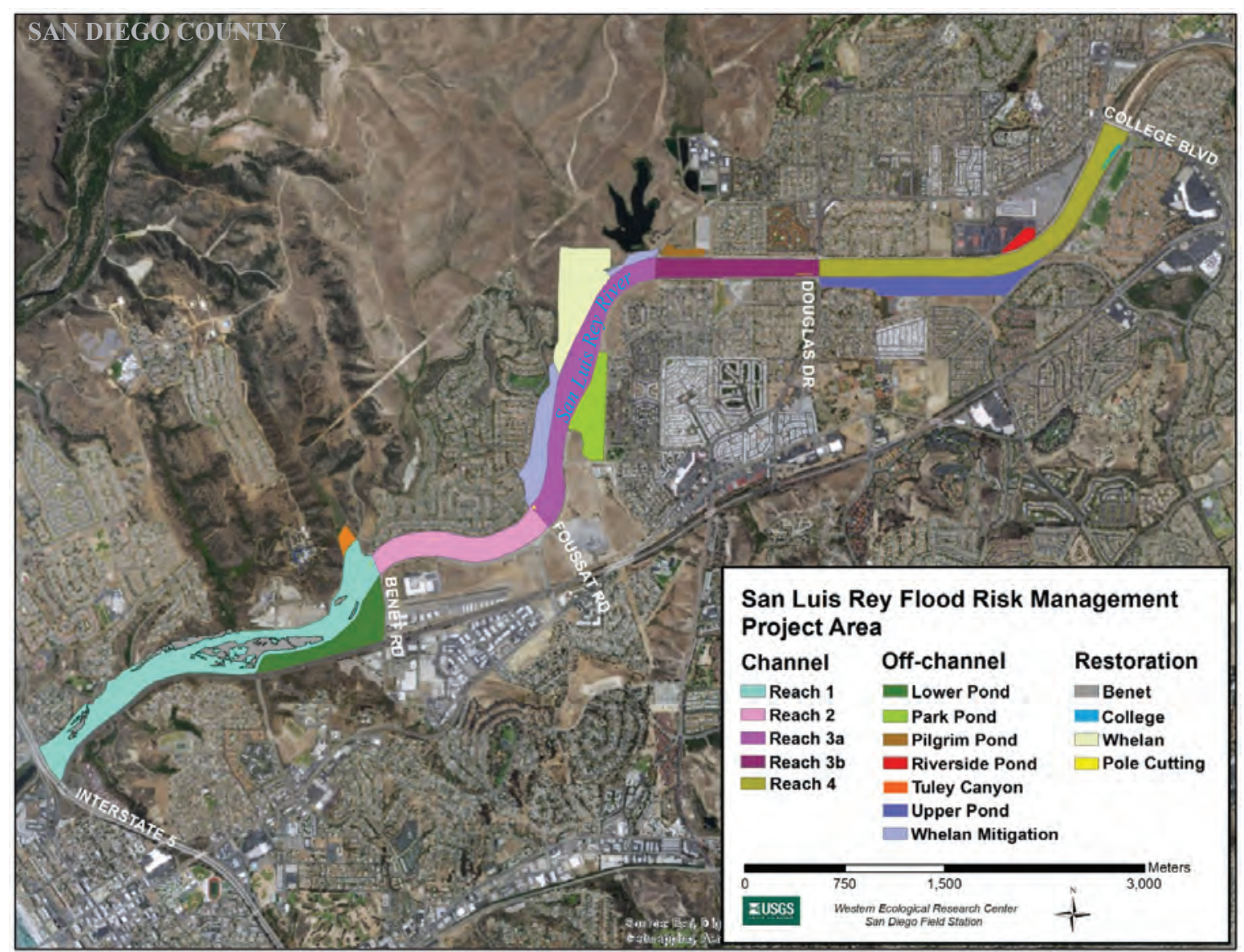

Map image is the intellectual property of Esri and is used herein under license.

Copyright (c) 2020 Esri and its licensors. All rights reserved.

Figure 1. Least Bell's Vireo and Southwestern Willow Flycatcher survey and monitoring sites at the San Luis Rey Flood Risk Management Project Area, California, in 2020.

The seven Off-channel sites include one historic restored site north of the levee and west of Whelan Lake and six in the detention ponds. There are two large restoration sites, one in Reach 1 (Benet Restoration) and one in Whelan Mitigation (Whelan Restoration). One smaller restoration site is located in Reach 4 (College Restoration).

Before the 2006 vireo breeding season, the U.S. Army Corps of Engineers began two flood risk management activities for the San Luis Rey Flood Risk Management Project: (1) exotic species eradication and (2) flood risk management of river channel vegetation. Exotic species eradication primarily included removal and control of giant reed, but other exotic species such as pepperweed (Lepidium latifolium), tamarisk (Tamarix ramosissima), and other non-native tree species also were targeted for removal. Exotic species were physically removed or treated with herbicide. The purpose of the flood risk management was to remove vegetation from the San Luis Rey flood control channel to provide a level of flood conveyance of 2,016 cubic meter per second $\left(\mathrm{m}^{3} / \mathrm{s}\right.$; equivalent to a 150 -year flood event; U.S. Fish and Wildlife Service, 2006b). In addition, a one-time mowing and mulching task was done in 2005 to reduce the risk of flooding during the 2006 rainy season. Ongoing flood risk management of river channel vegetation includes rotational and annual vegetation mowing in phases. Phase 1 includes vegetation clearing in Reaches $1-4$ to achieve a minimum flow conveyance of $1,500 \mathrm{~m}^{3} / \mathrm{s}$ (equivalent to a 100 -year flood event). Phase 2 includes mowing associated with maintaining the Phase 1 mowing area as well as restoration or creation of habitat for vireos and flycatchers. Phase 3 includes mowing associated with maintaining the Phase 1 mowing area as well as small sections of vegetation mowing in Reach 1 and Reach 3a. Rotational mowing is done every 5 years, alternating between two 18-23-m-wide strips of vegetation (Rotations 1 and 2) such that each strip is mowed every 10 years. For a detailed description of the timeline and vegetation treatments and management, see appendix 1 .

In fall 2019, annual Phase 1 and 2 mowing in reaches 1-4 was completed. In total, 31.4 ha was mowed (appendix 1). 
Table 1. Least Bell's Vireo and Southwestern Willow Flycatcher survey sites at the San Luis Rey Flood Risk Management Project Area, California, in 2020.

\begin{tabular}{|c|c|}
\hline Survey site & Description \\
\hline \multicolumn{2}{|r|}{ Channel sites } \\
\hline Reach 1 & From Interstate 5 to Benet Road. \\
\hline Benet Restoration & Active restoration began in 2012 . \\
\hline Reach 2 & From Benet Road to Foussat Road. \\
\hline Reach 3a & From Foussat Road to Whelan canal. \\
\hline Reach $3 b$ & From Whelan canal to Douglas Drive. \\
\hline Reach 4 & From Douglas Drive to College Boulevard. \\
\hline College Restoration & Active restoration began in 2014. \\
\hline \multicolumn{2}{|r|}{ Off-channel sites } \\
\hline Lower Pond & Detention pond with historic restored habitat, west of Benet Road and south of the levee. \\
\hline Park Pond & $\begin{array}{l}\text { Detention pond with historic restored habitat, located south of the levee, between Douglas Drive } \\
\text { and Foussat Road. Adaptive habitat management (mowing in } 2015 \text { and planting in 2017). }\end{array}$ \\
\hline Pilgrim Pond & Detention pond with historic restored habitat, north of Reach 4. \\
\hline Riverside Pond & Detention pond with historic restored habitat, north of Reach $3 \mathrm{~b}$. \\
\hline Tuley Canyon & Detention pond with historic restored habitat, west of Benet Road and north of the levee. \\
\hline Upper Pond & $\begin{array}{l}\text { Detention pond with historic restored habitat located south of levee between College Boulevard } \\
\text { and Douglas Drive. Adaptive habitat management (mowing in } 2015 \text { and planting in 2017). }\end{array}$ \\
\hline Whelan Mitigation & Historic restored habitat north of levee, between Whelan canal and Foussat Road. \\
\hline Whelan Restoration & Active restoration began in 2014 . \\
\hline
\end{tabular}

There were three Restoration areas within the Project Area: an exotic plant removal program in Reach 1 (Benet Restoration) that began in October 2012 and two projects that started in March 2014 (appendix 2, figs. 2.1-2.4). The largest project, focused on providing flycatcher habitat, was on the north side of the river channel in the eastern section of the Whelan Mitigation site (Whelan Restoration). A rock levee was removed and graded to below ground level, allowing flooding from the main channel to mimic more natural river flows. A second, smaller project occurred on the south side of Reach 4 near the College Boulevard bridge (College Restoration). Restoration activities included planting, bi-monthly watering, and spraying weeds with herbicide through 2015. Since 2016, there has been no watering or herbicide treatment, but we continued to classify these areas as Restoration sites and evaluate them separately. In addition to the three Restoration sites, in spring 2014, several small areas of the river were planted with pole cuttings, and in 2017, two of the Off-channel ponds were planted as a part of adaptive habitat management. These areas were considered passive restoration and were not included with our Restoration sites or included in any of our analyses of Treatment Index.

The purpose of this study was to document the status of vireos and flycatchers at the Project Area and characterize habitat structure and composition within the Project Area (fig. 1). Specifically, our goals for vireos were to (1) determine the size and composition of the vireo population; (2) characterize habitat used by vireos; (3) band vireos and resight banded vireos to estimate vireo survivorship, site fidelity, and dispersal; and (4) assess the effects of vegetation removal on vireo reproductive success and productivity by monitoring established nest monitoring plots in the Channel and Off-channel sites. Our goals for flycatchers were to (1) determine the size and composition of the Willow Flycatcher population at the Project Area, (2) document and monitor nesting activities of resident flycatchers, and (3) band and resight all flycatchers to facilitate the estimation of flycatcher survivorship and movement. The purpose of the habitat component of the study was to (1) provide post-treatment data on the habitat composition and structure of the Project Area including areas that underwent vegetation removal in 2005, 2007-12 and 2014-15, and 2017-19 and (2) characterize habitat use by vireos in response to vegetation management at the Project Area. These data, when combined with data from other years, will inform natural resource managers about the status of these endangered species at the Project Area and guide modification of land use and management practices as appropriate to ensure the species' persistence. 
Table 2. Site attributes of the Channel, Off-channel, and Restoration monitoring sites at the San Luis Rey Flood Risk Management Project Area, California, in 2020.

[Channel $=$ Reach 1, Reach 2, Reach 3a, Reach 3b, and Reach 4 survey sites.]

\begin{tabular}{|c|c|c|c|c|c|c|c|}
\hline \multirow[b]{2}{*}{ Attribute } & \multirow[b]{2}{*}{ Channel } & \multicolumn{3}{|c|}{ Off-channel } & \multicolumn{3}{|c|}{ Restoration } \\
\hline & & Park Pond & Upper Pond & $\begin{array}{l}\text { Whelan } \\
\text { Mitigation }\end{array}$ & $\begin{array}{c}\text { Benet } \\
\text { Restoration }\end{array}$ & $\begin{array}{c}\text { Whelan } \\
\text { Restoration }\end{array}$ & $\begin{array}{c}\text { College } \\
\text { Restoration }\end{array}$ \\
\hline $\begin{array}{r}\text { Habitat } \\
\text { type }^{1}\end{array}$ & Mixed willow & $\begin{array}{c}\text { Riparian } \\
\text { scrub }\end{array}$ & $\begin{array}{l}\text { Riparian scrub/ } \\
\text { mixed } \\
\text { willow }\end{array}$ & $\begin{array}{l}\text { Mixed willow/ } \\
\text { riparian scrub }\end{array}$ & Mixed willow & $\begin{array}{l}\text { Mixed willow/ } \\
\text { riparian } \\
\text { scrub }\end{array}$ & Mixed willow \\
\hline $\begin{array}{r}\text { Dominant } \\
\text { canopy } \\
\text { species }\end{array}$ & $\begin{array}{l}\text { Red/arroyo } \\
\text { willow, black } \\
\text { willow }\end{array}$ & $\begin{array}{l}\text { Sandbar } \\
\text { willow, } \\
\text { mule fat }\end{array}$ & $\begin{array}{l}\text { Sandbar } \\
\text { willow, } \\
\text { mule fat, } \\
\text { red/arroyo } \\
\text { willow, } \\
\text { black willow }\end{array}$ & $\begin{array}{l}\text { Black willow, } \\
\text { mule fat, red/ } \\
\text { arroyo willow }\end{array}$ & $\begin{array}{l}\text { Red/arroyo } \\
\text { willow, } \\
\text { black willow }\end{array}$ & $\begin{array}{l}\text { Sandbar } \\
\text { willow, } \\
\text { mule fat, } \\
\text { red/arroyo } \\
\text { willow, } \\
\text { black } \\
\text { willow }\end{array}$ & $\begin{array}{l}\text { Black willow, } \\
\text { mule fat, } \\
\text { red/arroyo } \\
\text { willow }\end{array}$ \\
\hline Disturbance & $\begin{array}{l}\text { Homeless camps; } \\
\text { moderate-heavy } \\
\text { human use }\end{array}$ & $\begin{array}{l}\text { Homeless } \\
\text { camps, } \\
\text { pets, } \\
\text { recreation; } \\
\text { heavy } \\
\text { human use }\end{array}$ & $\begin{array}{l}\text { Homeless } \\
\text { camps, pets, } \\
\text { recreation; } \\
\text { heavy } \\
\text { human use }\end{array}$ & $\begin{array}{l}\text { Homeless camps; } \\
\text { moderate-heavy } \\
\text { human use }\end{array}$ & $\begin{array}{l}\text { Exotic plant } \\
\text { control; } \\
\text { moderate } \\
\text { homeless } \\
\text { use }\end{array}$ & $\begin{array}{l}\text { Exotic plant } \\
\text { control; } \\
\text { some } \\
\text { homeless } \\
\text { use }\end{array}$ & $\begin{array}{l}\text { Exotic plant } \\
\text { control; } \\
\text { some } \\
\text { homeless } \\
\text { use }\end{array}$ \\
\hline
\end{tabular}

${ }^{1}$ Listed in order of dominance.

\section{Methods}

\section{Surveys}

Vireo and flycatcher surveys have been done at the Project Area every year since 2006. In 2020, four protocol surveys were done between March 31 and July 20, 2020, and followed standard survey techniques developed and recommended by the California Least Bell's Vireo Working Group (now known as the California Riparian Birds Working Group) and USFWS Least Bell's Vireo survey guidelines (U.S. Fish and Wildlife Service, unpub. data, 2001). We supplemented these protocol surveys with weekly territory monitoring visits; therefore, most survey sites were visited more than 10 times throughout the breeding season, resulting in complete coverage of the Project Area. We used recorded callbacks as needed during surveys and monitoring to confirm absence of vireos in areas in which no birds were detected and to attract males to check leg bands. Vireo field work was done by Armand Amico, Trevin Braun, Rachel Guinea, Alexandra Houston, Scarlett Howell, Suellen Lynn, Shannon Mendia, Ryan Pottinger, and Ben Stubbs (all under USFWS permit TE-829554), with assistance provided by Jessica Medina, Max Moore, and Gloria Salas.
We completed four protocol flycatcher surveys of the Project Area between May 20 and July 20, 2020, completing one survey during each of the four survey periods (U.S. Fish and Wildlife Service, 2000, Sogge and others, 2010). Flycatcher field work was done by Armand Amico, Rachel Guinea, Alexandra Houston, Suellen Lynn, Shannon Mendia, and Ryan Pottinger (all under USFWS permit TE-829554) with assistance provided by Jessica Medina, Max Moore, and Gloria Salas.

For both species, observers moved slowly (1-2 km per hour [0.6-1.2 mile per hour]) through the riparian habitat while searching and listening for vireos or flycatchers. Observers walked along the north and south levees to survey the flood control channel. In wider stands, observers traversed the habitat to detect all birds throughout its extent. Surveys were done between dawn and early afternoon, depending on wind and weather conditions. For each bird encountered, investigators recorded age (adult or juvenile), sex, breeding status (paired, single, unknown, or transient), and whether the bird was banded. Birds were considered transients if they were not detected on two or more consecutive surveys after an initial detection. Vireo locations were mapped using ArcGIS Collector and Survey 123 on Samsung Galaxy S7 and S8 and LG G5 mobile phones with Android operating systems 
and built-in Global Positioning System (GPS) to determine geographic coordinates (World Geographic System of 1984, WGS 84). Distance to the nearest surface water was recorded for each flycatcher location. Dominant native and exotic plants were recorded within each vireo and flycatcher territory, and percent cover of native vegetation was estimated using cover categories of less than 5 percent, 5-50 percent, 51-95 percent, and greater than 95 percent. Overall habitat type was specified according to the following categories:

- Mixed willow riparian: Habitat dominated by one or more willow species, including black willow, arroyo willow, and red willow, with mule fat as a frequent co-dominant.

-Willow-cottonwood: Willow riparian habitat in which cottonwood is a co-dominant.

-Willow-sycamore: Willow riparian habitat in which California sycamore (Platanus racemosa) is a co-dominant.

- Sycamore-oak: Woodlands in which California sycamore and coastal live oak (Quercus agrifolia) occur as co-dominants.

- Riparian scrub: Dry or sandy habitat dominated by sandbar willow or mule fat, with few other woody species.

- Upland scrub: Coastal sage scrub next to riparian habitat.

- Non-native: Areas vegetated exclusively with non-native species, such as giant reed and tamarisk.

\section{Nest Monitoring}

We monitored vireo nests to evaluate the effects of native and exotic vegetation removal on nest success and productivity. Nest monitoring was done from March 30 until the last nest fledged on August 4, 2020. We performed work at three general site types: (1) within the flood channel where exotic and native vegetation removal has occurred regularly (Channel); (2) at three sites next to the flood channel (Upper Pond, Park Pond, and Whelan Mitigation; Off-channel); and (3) at three sites that have been restored (Restoration), two of which were within the Channel (Benet Restoration in Reach 1 and College Restoration in Reach 4) and one situated Off-channel (Whelan Restoration within Whelan Mitigation).

Territory boundaries were delineated by biologists in the field by circumscribing vireos' nesting, singing, and foraging locations. In 2017, we began excluding areas in a vireo's territory that were obviously avoided (for example, the vireo used the edges of the river channel but avoided the center) by creating two unconnected polygons, as opposed to a single large one spanning the area. We classified territories quantitatively by site type in ArcGIS (version 10.5, ESRI, 2016) using territory boundaries and the boundaries of the three site types (Channel, Off-channel, and Restoration). If a territory straddled more than one site type, we assigned it to the site type that comprised more than 50 percent of the territory. Sixty-three Channel vireo pairs and 1 single male, 28 Off-channel pairs and 3 single males, and 5 Restoration pairs were monitored during the 2020 breeding season.

Pairs were observed for evidence of nesting, and their nests were located. We visited nests as infrequently as possible to minimize the chances of leading predators or Brown-headed Cowbirds to nests; typically, there were three to four visits per nest. The first visit was timed to determine the number of eggs laid, the next visits to determine hatching and age of young, and the last to band nestlings (see next section). We removed cowbird eggs from nests depending on when they were found. In nests with fewer than three vireo eggs, cowbird eggs were removed no sooner than the 7th day of incubation to minimize the possibility of nest abandonment in response to the removal. We removed cowbird eggs from nests containing 3 or more vireo eggs as they were found. Cowbird nestlings were removed immediately from nests. Fledging was determined through direct observation of fledglings in the territory or, in some rare cases, inferred from an accumulation of feather dust and fecal material in the nest, indicative of vireo fledging. We recorded characteristics of nests, including nest height, host plant species, host height, distance to edge of host plant, and distance to edge of host clump following abandonment or fledging of nests.

\section{Banding}

The primary goals of banding vireos at the San Luis Rey Flood Risk Management Project Area were (1) to assess vireo site fidelity in response to vegetation management, (2) to examine natal dispersal within and outside of the Project Area in response to vegetation management, and (3) to understand how vegetation removal and alteration affected vireo demography. We banded nestlings from monitored nests at 6-7 days of age with a single dark blue anodized numbered federal band on the left leg. We captured adult vireos in mist nets at all of the monitoring sites and banded them with a unique combination of colored plastic and anodized metal federal bands, including an anodized dark blue band to designate the San Luis Rey River as the bird's site of origin. Adults previously banded as nestlings with a single numbered metal federal band (natal birds) were target netted to determine their identity, and their original band was supplemented with other bands to generate a unique color combination. These data will supplement banding data currently being gathered by the U.S. Geological Survey (USGS) and other investigators on nearby vireo populations on the upper San Luis Rey River and the Santa Margarita River on Marine Corps Base Camp Pendleton (MCBCP). 


\section{Survivorship Estimates}

During surveys and nest monitoring activities, we attempted to resight all vireos to determine if they were banded, and if so, to confirm the vireos' identity by reading the unique color band combination or by recapturing birds with single federal bands. We used resighting and recapture data to calculate over-winter survivorship or the fraction of all individuals present at the Project Area in 1 year that returned the following year.

Imperfect detectability of banded individuals is typical of mark-recapture studies and occurs for various reasons (for example, females are more cryptic and may be missed on surveys, birds were detected as banded but their full color combinations [and thus identities] were not obtained; birds with single federal bands were not recaptured and thus their identities not determined). To account for individuals that were present but not detected, we used RMark (Laake, 2013) which uses Program MARK (White and Burnham, 1999) to model over-winter survivorship. Over-winter survivorship was calculated from 2006 to 2020 by creating an encounter history matrix of all individual vireos ever detected in the Project Area and whether or not they were observed in each year from 2006 to 2019. Vireos were grouped by age (originally encountered as a first-year bird [usually nestling but sometimes fledglings] versus originally encountered as an adult) and sex (female versus male). Survivorship was assumed to be constant for adults once they survived their first year. We created two sets of models. The first set included only adult captures, in which we modeled the influence of sex, year, and precipitation over the previous bio-year (July 1-June 30; National Oceanic and Atmospheric Administration [NOAA], 2020) on vireo survivorship and the influence of sex on detection probability. The second model set included both adult and juvenile vireos and modeled the influence of age, year, precipitation on survivorship, and year on detection probability. This model set did not include sex because we were unable to determine sex of vireos banded as juveniles unless they returned and were recaptured and identified as adults. Therefore, only the juveniles that survived their first winter were retroactively classified as male or female, which would severely bias the estimate of sex-related survivorship of first-year vireos.

Models created for survivorship in RMark only included detections from sites at which survey effort has been consistent from 2006 to 2020 (for example, lower San Luis Rey River Project Area, middle San Luis Rey River, MCBCP). Incidental resights outside of these survey sites were excluded from analysis. We excluded one adult with unknown sex from our first model set analysis because we were not interested in defining characteristics of this group.

We used an information-theoretic approach (Akaike's Information Criteria for small sample sizes or $\mathrm{AIC}_{\mathrm{c}}$; Burnham and Anderson, 2002) to evaluate support for the models. To evaluate the influence of sex and year on detection probability we compared models holding survivorship constant. For the adult-only models, we found that detection probability was influenced by sex, so it was included in all models of vireo survivorship. For models with adults and nestlings, we evaluated the effects of year on detection probability by comparing models with survivorship varying by age. We found that detection probability differed by year, so we included it in all of our models to evaluate survivorship. We used logistic regression with a logit link to build and rank models by $\mathrm{AIC}_{\mathrm{c}}$ and present annual real estimates from the top model. If there was support for multiple models (change in $\mathrm{AIC}_{\mathrm{c}}\left[\Delta \mathrm{AIC}_{\mathrm{c}}\right]$ less than 2), we averaged all models using $\mathrm{AIC}_{\mathrm{c}}$ weights to obtain annual real estimates of survivorship for adult females, adult males, all adults, and all first-year vireos. We also evaluated the effect of covariates within our top models by calculating the odds ratio for each covariate (the odds that the covariate had an effect on survivorship where "no effect" equals 1 , negative effect is less than 1 , positive effect is greater than 1). We then calculated the 95-percent confidence interval (CI) of the odds ratio to determine the likelihood that the effect was significant. Where the confidence interval was greater than or less than 1, we concluded that we had 95-percent confidence that the covariate had a positive or negative effect on survivorship relative to the reference.

\section{Site Fidelity and Movement}

We determined site fidelity of adult banded vireos by measuring the distance between the center of an individual's breeding territory in 2019 and the center of the same individual's breeding territory in 2020. Vireos exhibited site fidelity if they returned to within $100 \mathrm{~m}$ of their 2019 territory. Site fidelity was calculated for the same categories analyzed for survivorship (see previous section), except that only individuals with known territory locations during the last year that were detected before 2020 were included (for example, juveniles banded after fledging were excluded because their natal territories could not be confirmed in light of their capacity for substantial movement). We examined site fidelity to identify patterns indicative of relaxation of site fidelity in response to habitat alteration associated with vegetation clearing. To do this, we analyzed the distance moved by territorial males, hypothesizing that movement would be greater (site fidelity weaker) in years following vegetation treatment than in years where vegetation was undisturbed. We investigated the effect of a Treatment Index (see "Effects of Treatment" in the "Vegetation Data Analysis" section) on the movement of birds between 2019 and 2020. We focused on banded males because sample sizes for banded females were low, and females in general tend to exhibit lower site fidelity than males.

We examined first-year dispersal in 2020 and compared it to dispersal in previous years. We compared the proportion of first-year vireos that originated at the Project Area and returned to the Project Area to the proportion of first-year vireos that returned to nearby areas outside of the Project Area. 
Because some natal vireos were not detected or identified during their first year of dispersal, but were recaptured in subsequent years, our initial estimates were adjusted to include vireos that were not detected during their first year of dispersal. Although we were unable to determine their exact territory location during their first year, we can conclude that birds recaptured outside of the Project Area likely were not present at the Project Area because of our high success in recapturing and resighting vireos within the Project Area.

\section{Analysis of Nesting Data}

We used Pearson's chi-square analysis and Fisher's exact tests to determine if there were differences in nest success, hatching rates, and fledging rates between Channel, Off-channel, and Restoration pairs. We included a "Mixed" category for instances where (1) a territory was categorized as one site type, but the vireos placed at least one nest in another site type or (2) vireos nested in two site types within the same territory. For example, we had territories that were categorized as "Restoration" (50 percent or more of the total territory area fell within the boundaries of the restoration), but the vireos placed their nest(s) within the Channel, avoiding areas of active restoration. In total, two territories were considered "Mixed" in 2020. For analyses involving the nest as the unit of analysis, we used the location of the nest (for example, a territory categorized as Channel could have a nest in a Restoration site). For any analyses of reproductive success or productivity that involved a measure of success per pair or territory, we analyzed Mixed territories separately. Chi-square tests were used when sample sizes were sufficient; Fisher's exact tests were used when one or more categories contained fewer than five samples. We used two-sample $t$-tests, Mann-Whitney $U$-tests (two groups), and Kruskal-Wallis tests (three or more groups) to determine if there were differences in nest site characteristics between successful and unsuccessful nests within and between the Channel, Off-channel, and Restoration sites. $T$-tests were used when distributions were normal and variances were similar; Mann-Whitney $U$-tests or Kruskal-Wallis tests were used when the data violated these assumptions. We used analysis of variance and Tukey's post-hoc pairwise comparisons to determine if there were differences between Channel, Off-channel, and
Restoration sites in average clutch size and average number of young per pair in 2020 and average clutch size and number of young fledged per pair by year (2006-20).

\section{Effects of Treatment}

We created an index of treatment (Treatment Index) to evaluate the cumulative effects of vegetation removal over time for 2019 and 2020 vireo territories. We restricted treatment type for this index to the vegetation removal that occurred from 2005 , 2007-12, 2014-15 or 2017-19 in which vegetation (native or exotic) was cleared to the ground. We did not include any restoration or herbicide treatments because these treatments were distinct from vegetation removal and analysis of them was beyond the scope of this project. We limited our analysis of Treatment Index to territories in the Channel because Off-channel adaptive habitat management activities mitigated the impact of the vegetation removal, making the Treatment Index for those territories unusable for our analyses. We calculated the percent of each territory area that was treated in each year $(2005,2007-12,2014-15$, and 2017-19) by overlaying the 2019 and 2020 territory boundaries with the treatment areas in ArcGIS. Territory boundaries were created to include the bird location points collected using GPS throughout the field season. Treatment boundaries were generated from the location data collected using GPS in the field by a RECON Environmental, Inc. (https://www.recon-us.com/) biologist who walked the entire treatment boundary during vegetation removal activities. Because treatments have been occurring since 2005, it was possible to have multiple years of treatments as well as overlap among treatments within a single territory. Because early successional vegetation can recover quickly following disturbance, we assumed that the influence of the vegetation removal diminished over time; therefore, when there was overlap in treated areas among years, we used the most recent treatment year to calculate the Treatment Index (fig. 2). To calculate the Treatment Index, we used the percent of the territory area treated weighted by the squared inverse of the time $\left(t^{2}\right)$ since treatment summed across all treatment years. We chose $t^{2}$, rather than $t$ because we wanted to capture the effect of the treatment diminishing quickly over time. We used the following formula:

$$
\text { Treatment Index }=\sum_{t=2005}^{2019} \text { percent Territory Area Treated }{ }_{t} \times 1 / n_{t}^{2}
$$

where

$$
\begin{aligned}
t & \text { is the year of treatment } \\
n & \text { is the years since treatment, and } \\
n=1 & \text { is the first breeding season following treatment. }
\end{aligned}
$$




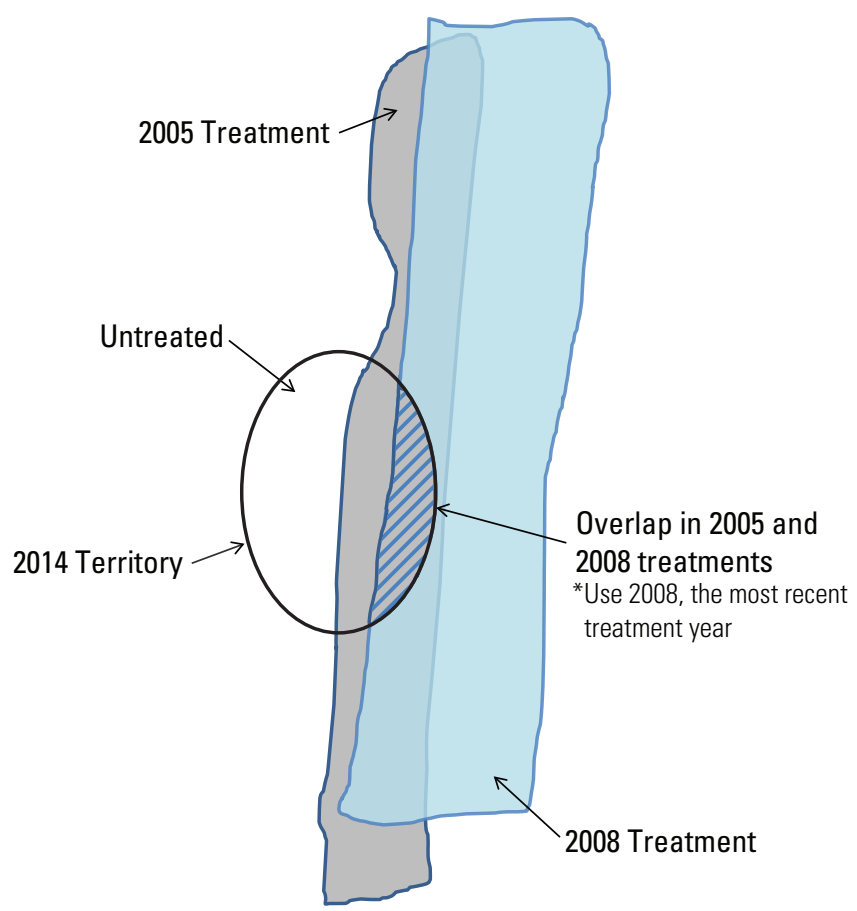

Figure 2. Least Bell's Vireo territory boundary with two treatments (2005 and 2008 vegetation removal) and a section of overlap between the two treatments.

Note that there was no treatment in 2006, 2013, or 2016 so values for these years $=0$ and drop out of the equation.

To calculate the Treatment Index, calculate the percent area that intersects with the territory for (1) 2005 treatment and (2) overlap in 2005 and 2008 treatments.

We performed three sets of analyses using the Treatment Index. For all analyses of the Treatment Index, we excluded territories that overlapped with areas of active restoration.

1. We compared the Treatment Index between occupied (monitored and non-monitored) territories and unoccupied vireo habitat within the Channel using a two-sample $t$-test. To generate a Treatment Index for unoccupied habitat, we used historic territory boundaries from 2006 to 2019 as a guide and subdivided habitat that was unoccupied in 2020 into units approximating vireo territories in size. We calculated the Treatment Index for the unoccupied historical territories within the Channel that did not overlap with restoration, creating a distribution of Treatment Indices for unoccupied habitat that allowed statistical comparisons with occupied territories. Habitat never occupied by vireos (for example, marsh, open water) during this study and unoccupied patches too small ( $\leq 0.2$ ha $[0.5$ acres]) for a territory were excluded from analysis. We hypothesized that the Treatment Index in occupied habitat would be lower than that of the unoccupied habitat, indicating that vireos were preferentially selecting habitat that was less treated or was treated less recently.
2. We used generalized linear models (GLM) in R (R Core Team, 2018) to evaluate whether treatment (Treatment Index) had an effect on vireo reproductive parameters for monitored territories within the Channel including the total number of (1) nests, (2) completed nests, and (3) fledglings per territory in 2020. We limited our analysis to Channel territories since 2018 because, in 2017, passive restoration including some planting, weeding, and watering occurred at two of our Off-channel locations, confounding the effect of the vegetation removal. We hypothesized that there would be an inverse relationship between the reproductive parameters and the Treatment Index (for example, the number of fledglings would decrease as the Treatment Index increased) and a positive relationship between the Treatment Index and the number of nests, as we might expect to see higher levels of nest failure in the lower quality (more treated) habitat. Treatment Index was a continuous, fixed effect. We assumed a Poisson distributed response to the reproductive parameters.

3. Finally, we used a GLM to test for the effect of the expected Treatment Index for 2019 territories on the distances that banded vireos moved between 2019 and 2020. We hypothesized that birds whose previous territories were heavily treated (had high Treatment Indices) would shift their territories a greater distance than those whose territories were less affected by, or were temporally further removed from, the treatment.

\section{Nest Survival Analysis}

We used RMark to model the effects of vegetation treatment on daily survival rate (DSR) of vireo nests. Calculation of nest success and the factors influencing it are critical components of studies of the breeding ecology of birds, particularly special status species. We calculated the DSR (the probability that a nest survived from one day to the next; Dinsmore and others, 2002). We used RMark to run program MARK to calculate DSR, which accounts for the variability in detection of nests at the various stages and allows for the analysis of the effects of covariates on DSR. In this study, we evaluated the effects on nesting success in two ways:

We looked at whether Treatment Index (for Channel territories only) had an impact on DSR in 2020 . We also looked at whether habitat structure at the nest (2006-20) was correlated with DSR by analyzing the relationship between total vegetation cover at each height category (see "Vegetation Study Design" section) and DSR.

We calculated nest survival across a 30-day cycle (4 days egg-laying, 14 days incubation, 12 days nestling period) in which incubation begins with the penultimate egg. We calculated age of nests at the time they were discovered by forward- or backward-dating of nests in relation to known dates of nest building, laying, or hatching. 
We used an information-theoretic approach (Burnham and Anderson, 2002) to evaluate support for statistical models reflecting a priori hypotheses regarding the effect of treatment and habitat variables on DSR. We hypothesized that DSR would be inversely related to the Treatment Index and would increase with increasing foliage cover at nest sites, particularly understory cover within $2 \mathrm{~m}$ (6.6 feet) of the ground, where vireos place their nests. We used logistic regression with a logit link to build models. First, we generated a constant survival model to serve as a reference for the effect of treatment and habitat variables on DSR. We then modeled the treatment and habitat covariates individually and evaluated support for each model in relation to the constant survival model and each other.

\section{Vegetation Study Design}

We sampled vegetation along permanent linear transects within three of the vireo monitoring sites (Channel and two Off-channel sites: Upper Pond and Whelan Restoration). Sampling points consisted of 2- by 2-m quadrats at $10-\mathrm{m}$ intervals along each transect; the number of points sampled varied with the length of each transect (fig. 3). Transects were originally established in 2006 by using a systematic sampling design. To capture the range of variability of riparian vegetation structure and composition, we positioned transects perpendicular to the river channel.
To provide uniform coverage, we placed transects at fixed distances from each other; distances varied with the size of the site. In the Channel, transects were placed at 200- or 400-m intervals depending on the width of the river. In Upper Pond, transects were placed every $100 \mathrm{~m}$. In addition, we sampled two 350-m transects at Whelan Mitigation (Whelan Restoration), that were initially surveyed from 1991 to 1993, to monitor riparian restoration by the U.S. Army Corps of Engineers (Kus, 1998). The Whelan Restoration transects were $75 \mathrm{~m}$ apart and oriented approximately parallel (320 degrees) to the flood control channel. Before 2014, this site was sampled and used as an Off-channel site in analyses. However, in 2014, it became a Restoration site and has been analyzed separately from the Channel and the Upper Pond sites since then.

We used a number of permanent and semi-permanent methods to ensure that transects could be resampled in future years. First, a 1.5-m metal rebar was driven into the ground, leaving 75 centimeters $(\mathrm{cm})$ above ground to mark the start of each transect. We spray-painted the rebar pink or orange and placed them at the intersection of the south levee and the riverbed. From the rebar, using a compass and tape measure, two field personnel measured the distances between sampling points. A numbered, wooden stake, spray-painted pink or orange, was placed in the ground and colored plastic flagging was tied nearby to aid in locating the points. Finally, we obtained geographic coordinates for each rebar and wooden stake using a GPS unit (Garmin GPS 12).

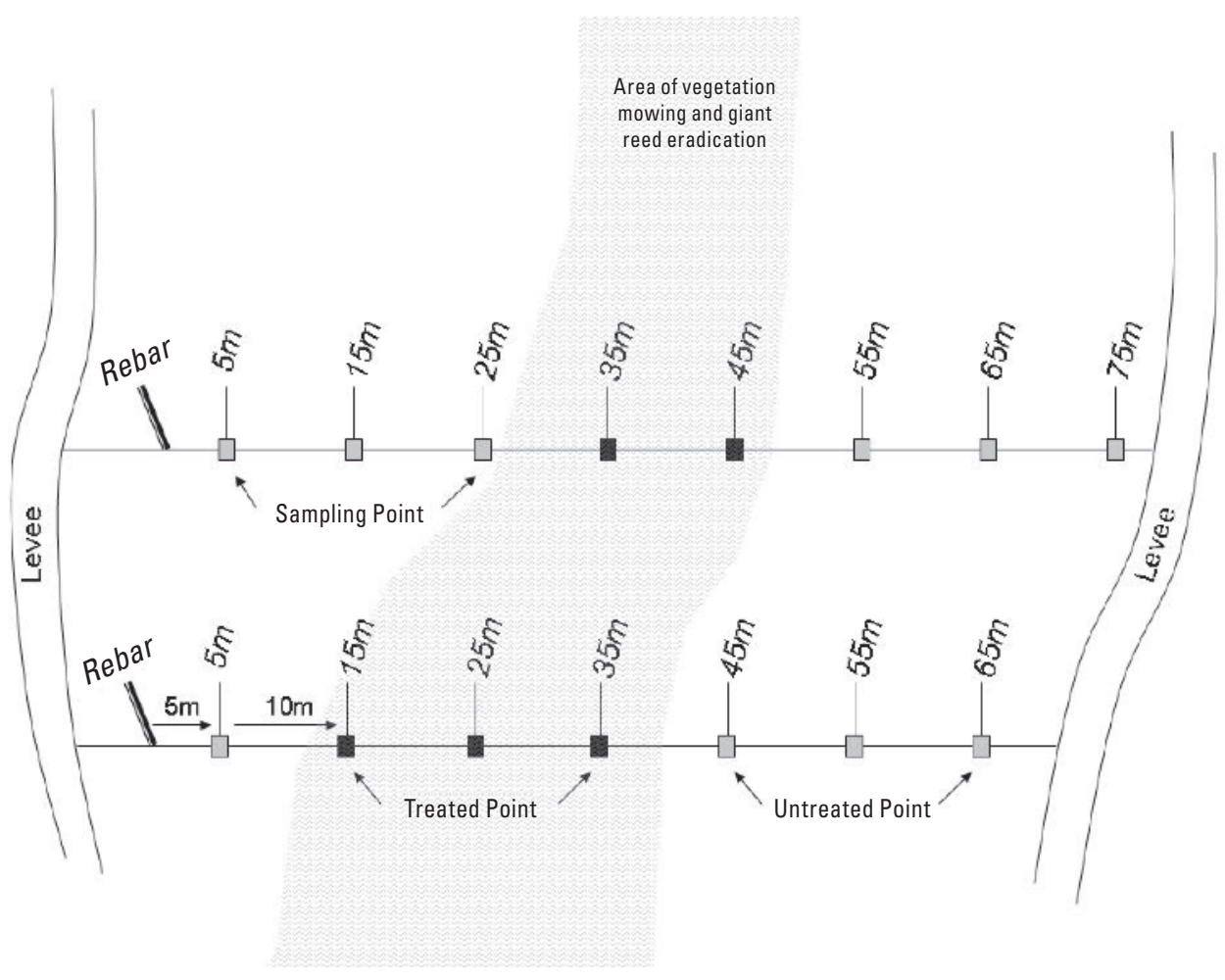

Figure 3. Vegetation transects in the Channel at the San Luis Rey Flood Risk Management Project Area, California, in 2020. 


\section{Vireo Habitat Use Study Design}

In addition to sampling vegetation along transects, we collected vegetation data at 49 randomly selected vireo territories. We sampled one nest and one paired random plot within each territory (hereafter "nest plots" and "territory plots," respectively) in the Channel and at Upper Pond. We did not sample vegetation at Restoration site nests because the sample was small, and our focus was determining the response of vireos to treatments (measured by the Treatment Index) rather than their response to restoration activities. Nest and territory plots consisted of four 2- by 2-m quadrats; 1 quadrat centered on the nest (or center for random plots) and the remaining three quadrats located $10 \mathrm{~m}$ from the nest/center and oriented at 0,120 , and 240 degrees from it (fig. 4). Territory plot locations were constrained using the "Buffer" tool in ArcGIS to create a 10-m negative buffer on the territory boundaries. This negative buffer ensured that the random sampling point for the quadrats at 0,120 , or 240 degrees would not fall outside of the territory boundaries. A positive 2-m buffer was created around nest locations and vegetation transect points to exclude these locations and prevent duplicating vegetation sampling. We then used the "Create Random Points" tool on the territory boundary buffer to select one random point between the buffered areas to serve as the center quadrat. Territories were excluded from analysis if they were too narrow to allow a 10 -m negative buffer, were in the "mixed" type category, or overlapped with Restoration.

\section{Vegetation Sampling}

Foliage cover at 1-m height intervals was estimated using the "stacked cube" method, developed specifically to

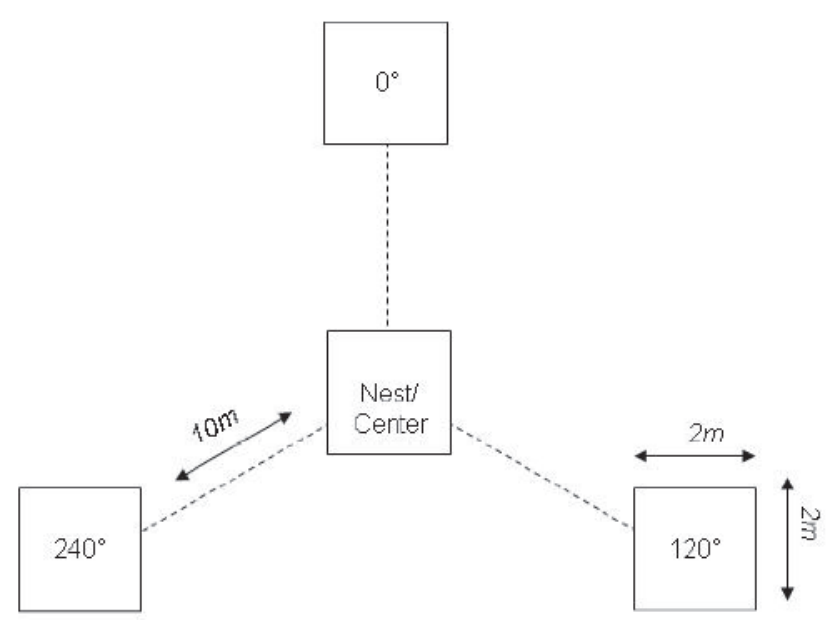

Figure 4. Nest-centered and territory vegetation plots sampled at the San Luis Rey Flood Risk Management Project Area, California, in 2020. characterize canopy architecture in structurally diverse riparian habitat (Kus, 1998). At each sampling point along a vegetation transect or in a nest/territory plot, we recorded canopy height and percent cover of vegetation, by species, within 1-m height intervals, using a modified Daubenmire (1959) scale with cover classes less than 1, 1-10, $11-25,26-50,51-75,76-90$, and greater than 90 percent. The sampling units were 2- by 2- by 1-m high "cubes," which were "stacked" vertically between the ground and the top of the canopy. Four 2-m length polyvinyl chloride pipes were placed on the ground to define quadrat boundaries, and a $7.5-\mathrm{m}$ tall fiberglass telescoping pole, demarcated in 1-m intervals, was used to determine height class and canopy height. Vegetation data were collected by USGS biologists Lisa Allen, Armand Amico, Alex Bartolo, Trevin Braun, Kim Geissler, Rachel Guinea, Marcus Hubbell, Barbara Kus, Rachelle McLaughlin, Jessica Medina, Shannon Mendia, Max Moore, Molly Morrissey, Ryan Pottinger, Gloria Salas, Ben Stubbs, Michelle Treadwell, and Stéphane Vernhet.

\section{Vegetation Data Analysis}

For analysis, we converted cover codes to class midpoints, which were then used to quantify foliage cover at each sampling point for nine height classes: $0-1 \mathrm{~m}$, greater than 1-2 m, greater than 2-3 m, greater than 3-4 m, greater than 4-5 m, greater than 5-6 m, greater than 6-7 m, greater than 7-8 $\mathrm{m}$, and greater than $8 \mathrm{~m}$. We examined percent cover for species that occurred at greater than 5 percent of the sampling points (more than 25 points). Species that were less common (less than 5 percent of the sampling points) were grouped together by plant life form, including tree, shrub, dead woody species, and freshwater marsh. Herbaceous species also were grouped together and included annual and perennial species (native and exotic), with the exception of nine exotic species: poison hemlock (Conium maculatum), pepperweed, fennel (Foeniculum vulgare), white sweet clover (Melilotus alba), black mustard (Brassica nigra), wild radish (Raphanus sativus), thistle (Cirsium sp.), ivy (Hedera sp.), and all grass species. These nine exotic species were combined and analyzed as exotics. We calculated average foliage cover across all height classes separately for the Channel, Upper Pond, and Whelan Restoration sites, separately. We used linear regression to examine the cumulative effects of vegetation management activities at these sites over time (2006-20) and to investigate any temporal trends that existed in percent cover at all height classes for each site. We focused on a cumulative approach because it allowed us to analyze the long-term effects of vegetation management within the Project Area. Comparisons between the intensively managed Channel sites and the less-managed Off-channel sites provided insight into how annual vegetation management has affected the structure of the vegetation in the Channel through time. 
We used data from the vegetation transects, nest plots, and territory plots to examine vireo habitat selection at two spatial scales. First, we compared vegetation structure at nest plots to that at territory plots to assess whether vireos were selecting nest sites non-randomly, relative to the vegetation available in the territory. Next, we compared territory plot data to transect data to evaluate whether vireos were establishing territories non-randomly with regard to the habitat available to them throughout the site. We performed these comparisons separately for the Channel and Upper Pond to evaluate the effect of vegetation treatment on vireo nest and territory placement. We used $t$-tests to test for differences in foliage cover between nest sites and the territory and between territories and the available habitat.

Averages are presented with standard deviations. We considered $P$ less than or equal to 0.10 to be significant for all statistical tests to avoid overlooking potentially important biological relationships relevant to the recovery of these endangered birds. Data were analyzed using Program R.

Data from the Project Area from 2006 to 2019, used in comparisons with current data, can be found in Ferree and Kus, U.S. Geological Survey, unpub. data, 2007, 2008a, b; Ferree and others, U.S. Geological Survey, unpub. data, 2010a, b, 2011, 2012, 2014, 2015; and Houston and others, U.S. Geological Survey, unpub. data, 2015, 2016, 2017, 2018, 2019.

\section{Results}

\section{Least Bell's Vireo}

In this section, we present the results from surveys and nest monitoring on Least Bell's Vireo population size and demographic parameters.

\section{Population Size and Distribution}

We identified a total of 161 vireo territories during surveys and weekly territory monitoring (table 3; appendix 2, figs. 2.1-2.4). The number of vireo territories increased from 128 in 2019, amounting to a 26-percent increase in 2020 (fig. 5; table 4). Of the 161 territorial males, 145 (90 percent) were confirmed as paired, and 4 ( 2 percent) were confirmed as single males. For the remaining 12 territories, we were unable to confirm pair status. We detected three transient vireos during surveys in 2020 (table 3).

Sixty-five percent of the territories $(105 / 161)$ were within the Channel. The remaining 35 percent of the territories $(56 / 161)$ were Off-channel. There were 6 Channel territories in Benet Restoration, 1 in College Restoration, and the remaining 98 Channel territories were outside of Restoration areas. There were 5Off-channelterritorieswithinWhelanRestoration, 15werewithin Whelan Mitigation, but outside of the Restoration area, and 36 were in other retention ponds (table 4; appendix 2, figs. 2.1-2.4).

Table 3. Number and breeding status of Least Bell's Vireos at the San Luis Rey Flood Risk Management Project Area, California, in 2020.

$[-$, not applicable $]$

\begin{tabular}{|c|c|c|c|c|c|}
\hline Survey site & $\begin{array}{c}\text { Known } \\
\text { pairs }\end{array}$ & $\begin{array}{c}\text { Unknown } \\
\text { status }\end{array}$ & $\begin{array}{l}\text { Single } \\
\text { males }\end{array}$ & $\begin{array}{c}\text { Total } \\
\text { territories }\end{array}$ & $\begin{array}{c}\text { Total } \\
\text { transients }\end{array}$ \\
\hline \multicolumn{6}{|c|}{ Channel sites } \\
\hline Reach 1 & 22 & 4 & - & 26 & - \\
\hline Benet Restoration & 6 & - & - & 6 & - \\
\hline Reach 2 & 12 & - & - & 12 & 1 \\
\hline Reach 3a & 16 & 1 & - & 17 & - \\
\hline Reach 3b & 16 & - & - & 16 & - \\
\hline Reach 4 & 25 & 1 & 1 & 27 & - \\
\hline College Restoration & 1 & - & - & 1 & - \\
\hline \multicolumn{6}{|c|}{ Off-channel sites } \\
\hline Lower Pond & 3 & 4 & - & 7 & - \\
\hline Tuley Canyon & 2 & - & - & 2 & - \\
\hline Whelan Mitigation & 13 & 1 & 1 & 15 & 2 \\
\hline Whelan Restoration & 5 & - & - & 5 & - \\
\hline Park Pond & 5 & 1 & - & 6 & - \\
\hline Pilgrim Pond & 1 & - & - & 1 & - \\
\hline Upper Pond & 16 & - & 2 & 18 & - \\
\hline Riverside Pond & 2 & - & - & 2 & - \\
\hline Total & 145 & 12 & 4 & 161 & 3 \\
\hline
\end{tabular}




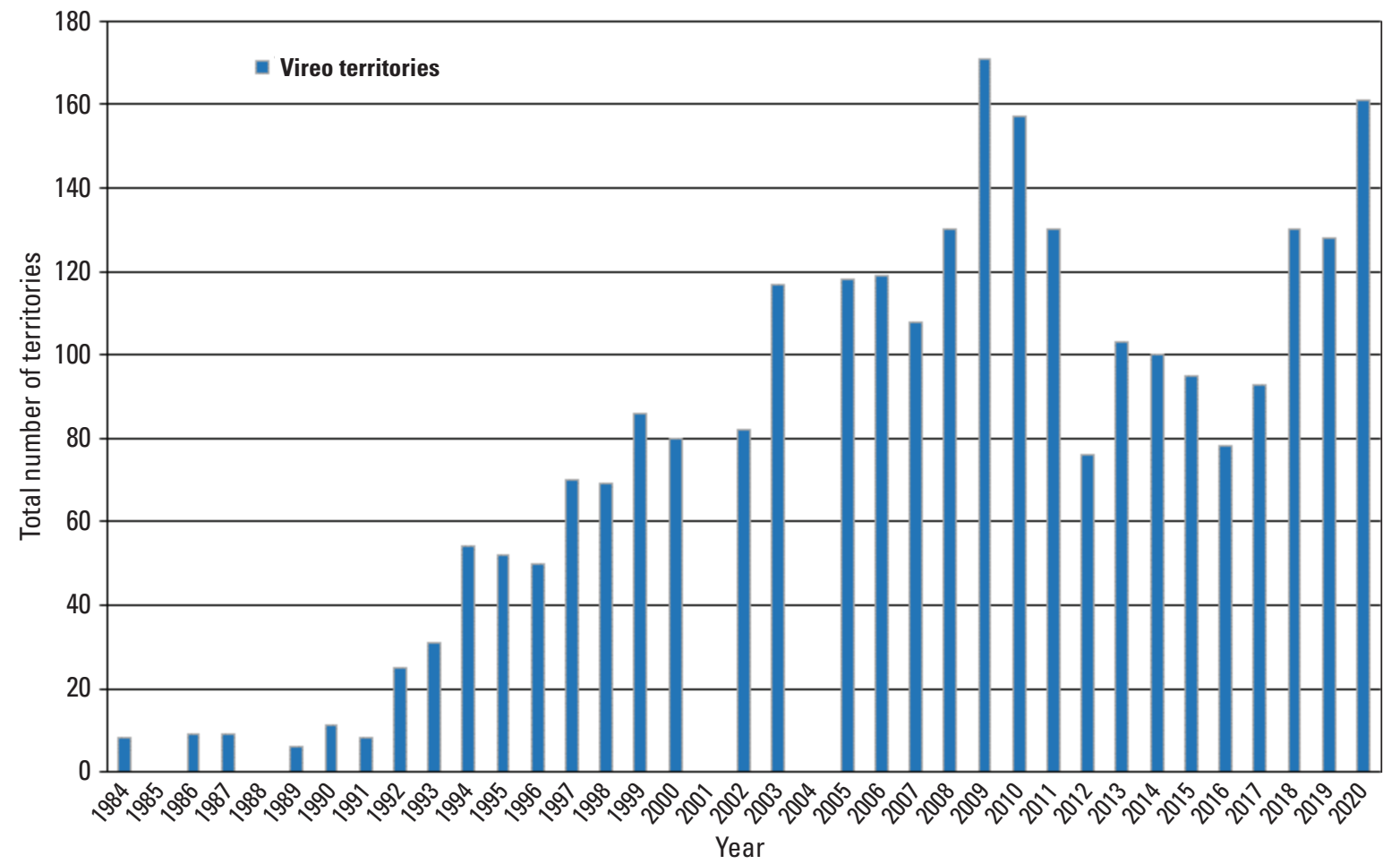

Figure 5. Number of Least Bell's Vireo territories from 1984 to 2020 at the San Luis Rey Flood Risk Management Project Area, California. Surveys were not done during 1985, 1988, 2001, or 2004.

From 2019 to 2020, the number of vireo territories in the Channel increased by 25 percent (from 84 to 105 ) and increased by 27 percent (from 44 to 56) within Off-channel sites (table 4). Vireo territory numbers increased for all Channel sites, with the exception of Reach 2, which decreased by one territory. The largest increases were in Reach 1 (nine territories, 39-percent increase),

Reach $3 b$ (six territories, 60-percent increase), and in Reach 4 (five territories, 23-percent increase). The majority of Off-channel sites also increased from 2019 to 2020. Only one site, Lower Pond, decreased by one territory, and two sites were stable between years (Park and Pilgrim Ponds). The remaining sites experienced increases, with the largest being Upper pond, which increased by six territories (50-percent increase, table 4).

\section{Effects of Treatment on Habitat Use}

To investigate whether vireos were selecting territories in habitat that was less affected by vegetation removal, we compared the Treatment Index of occupied vireo territories in the Channel to the Treatment Index of territories previously occupied, but unused, in 2020. Within the Channel, the average Treatment Index of unoccupied habitat $(0.25 \pm 0.29, n=103)$ was more than 5 times that of habitat occupied by vireos in $2020(0.04 \pm 0.05, n=80 ; t=-6.8$, $\mathrm{df}=127.1, P<0.01)$, indicating that vireos avoided the more heavily treated sections of the river channel. 
Table 4. Number and distribution of Least Bell's Vireo territories at the San Luis Rey Flood Risk Management Project Area, California, in 2006-20.

[-, not applicable]

\begin{tabular}{|c|c|c|c|c|c|c|c|c|c|c|c|c|c|c|c|}
\hline Survey site & 2006 & 2007 & 2008 & 2009 & 2010 & 2011 & 2012 & 2013 & 2014 & 2015 & 2016 & 2017 & 2018 & 2019 & 2020 \\
\hline \multicolumn{16}{|c|}{ Channel sites } \\
\hline Reach 1 & 13 & 7 & 10 & 23 & 23 & 17 & 10 & 13 & 14 & 22 & 15 & 22 & 27 & 17 & 26 \\
\hline Benet Restoration & - & - & - & - & - & - & - & 6 & 6 & 2 & 4 & 4 & 5 & 6 & 6 \\
\hline Reach 2 & 15 & 14 & 16 & 18 & 22 & 16 & 6 & 6 & 6 & 3 & 6 & 7 & 12 & 13 & 12 \\
\hline Reach 3a & 14 & 19 & 23 & 28 & 26 & 17 & 14 & 18 & 16 & 12 & 8 & 10 & 15 & 16 & 17 \\
\hline Reach $3 b$ & 13 & 14 & 13 & 17 & 16 & 18 & 5 & 4 & 6 & 5 & 4 & 7 & 11 & 10 & 16 \\
\hline Reach 4 & 21 & 21 & 25 & 32 & 24 & 18 & 10 & 14 & 15 & 16 & 12 & 10 & 20 & 22 & 27 \\
\hline College Restoration & - & - & - & - & - & - & - & - & 2 & 0 & 0 & 0 & 0 & 0 & 1 \\
\hline Total & 76 & 75 & 87 & 118 & 111 & 86 & 45 & 61 & 65 & 60 & 49 & 60 & 90 & 84 & 105 \\
\hline \multicolumn{16}{|c|}{ Off-channel sites } \\
\hline Lower Pond & 3 & 2 & 3 & 7 & 7 & 4 & 1 & 7 & 7 & 7 & 6 & 7 & 9 & 8 & 7 \\
\hline Tuley Canyon & 1 & 1 & 1 & 1 & 1 & 0 & 0 & 0 & 1 & 2 & 2 & 1 & 1 & 1 & 2 \\
\hline Whelan Mitigation & 14 & 9 & 12 & 15 & 16 & 12 & 11 & 13 & 6 & 6 & 4 & 6 & 8 & 13 & 15 \\
\hline Whelan Restoration & - & - & - & - & - & - & - & - & 4 & 3 & 3 & 3 & 5 & 3 & 5 \\
\hline Park Pond & 3 & 2 & 4 & 4 & 4 & 6 & 3 & 5 & 5 & 4 & 3 & 4 & 6 & 6 & 6 \\
\hline Pilgrim Pond & 1 & 1 & 1 & 1 & 0 & 2 & 0 & 2 & 0 & 0 & 0 & 1 & 1 & 1 & 1 \\
\hline Upper Pond & 20 & 17 & 21 & 24 & 17 & 19 & 15 & 14 & 11 & 12 & 11 & 11 & 10 & 12 & 18 \\
\hline Riverside Pond & 1 & 1 & 1 & 1 & 1 & 1 & 1 & 1 & 1 & 1 & 0 & 0 & 0 & 0 & 2 \\
\hline Total & 43 & 33 & 43 & 53 & 46 & 44 & 31 & 42 & 35 & 35 & 29 & 33 & 40 & 44 & 56 \\
\hline Grand total & 119 & 108 & 130 & 171 & 157 & 130 & 76 & 103 & 100 & 95 & 78 & 93 & 130 & 128 & 161 \\
\hline
\end{tabular}

\section{Nest Monitoring}

We monitored nesting activity in 100 territories within the San Luis Rey River Flood Risk Management Project Area monitoring areas (table 5; appendix 2, figs. 2.1-2.4; appendix 3 ). These territories were fully monitored, meaning that all nests within the territory were found and monitored during the breeding season. Of the 100 monitored territories, 4 were occupied by single males and therefore were excluded from nesting analyses. A total of 158 nests were monitored during the breeding season. Twenty of these nests were not completed and were subsequently excluded from calculations of nest success and productivity unless otherwise noted.

Additionally, one nest completed by an Off-channel vireo pair was located outside of the Project Area. This nest was included in calculations of nesting success and productivity per pair but was excluded from our analyses of vegetation structure, and Treatment Index.

\section{Nesting Attempts}

The average number of nesting attempts (including incomplete nests) over the course of the 2020 breeding season was $1.8 \pm 0.9$ (table 5). Fifty-two percent (50/96) of pairs re-nested after their first nest attempt, and 28 percent $(14 / 50)$ of these pairs initiated at least a third nesting attempt. A total of 7 successful pairs (11 percent, 7/64) attempted a re-nest after a successful nest. Of these, five pairs (71 percent, 5/7) successfully fledged two broods.

The majority of first nesting attempts in 2020 were initiated during late April and early May (fig. 6). The peak of nest initiation was during the week of April 26, 2020, when 35 percent (31/89) of first nests were initiated. Nesting occurred later in 2020 (median Julian day 125; May 4 in 2020) compared to 2019 (median Julian day 107) and also compared to the 14-year average (mean median Julian day 113 from 2006 to 2019; fig. 7). 
Table 5. Number of Least Bell's Vireo territories and nests monitored at the San Luis Rey Flood Risk Management Project Area, California, in 2020.

[Mixed territories had a territory classification that differed from one or more nest classifications (one territory was classified as Channel but had a nest located Off-channel while the second territory was classified as Off-channel but the vireo nested in the channel. Abbreviations: - , not applicable; \pm , plus or minus]

\begin{tabular}{lccccc}
\hline & Channel & Off-channel & Restoration & Mixed & Total \\
\hline Territories & 63 & 30 & 5 & 2 & 100 \\
Total number of pairs & 62 & 27 & 5 & 2 & 96 \\
Total number of nests monitored & 102 & 48 & 18 & - & 158 \\
Incomplete nests $^{2}$ & 9 & 5 & 2 & - & 16 \\
False nests $^{3}$ & 3 & 1 & 0 & - & 4 \\
Total number of completed nests & 90 & 42 & 6 & - & 138 \\
Completed nests/pair & $1.4 \pm 1.1$ & $1.5 \pm 0.8$ & $1.2 \pm 0.8$ & $1.5 \pm 0.7$ & $1.4 \pm 1.0$ \\
Total number of nest attempts/pair & $1.8 \pm 0.9$ & $1.9 \pm 0.9$ & $1.6 \pm 0.5$ & $1.5 \pm 0.7$ & $1.8 \pm 0.9$ \\
\hline
\end{tabular}

${ }^{1}$ All nests were in Whelan Restoration.

${ }^{2}$ Incomplete nests were partially built but not completed.

${ }^{3}$ False nests were partially built by the male only.

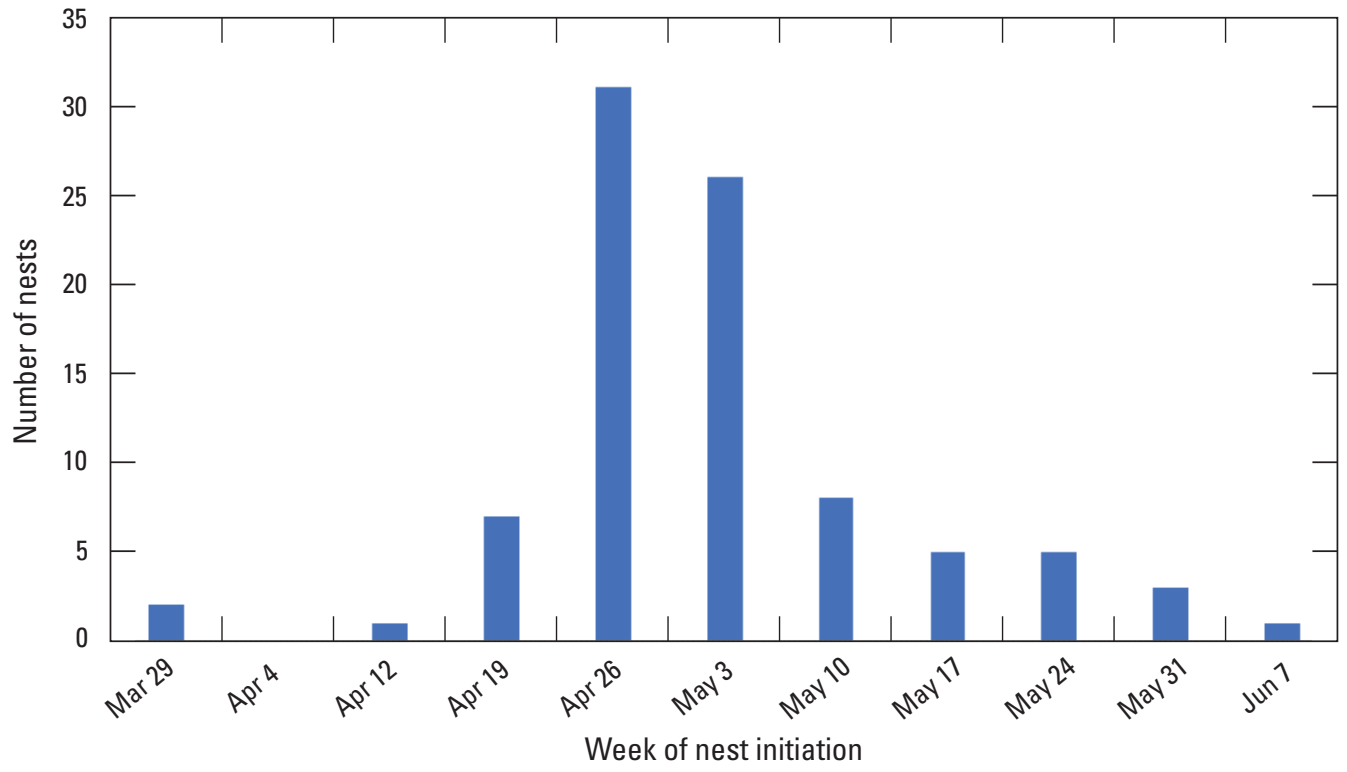

Figure 6. Number of first Least Bell's Vireo nests initiated (date first egg laid) by week at the San Luis Rey Flood Risk Management Project Area, California, 2020. 


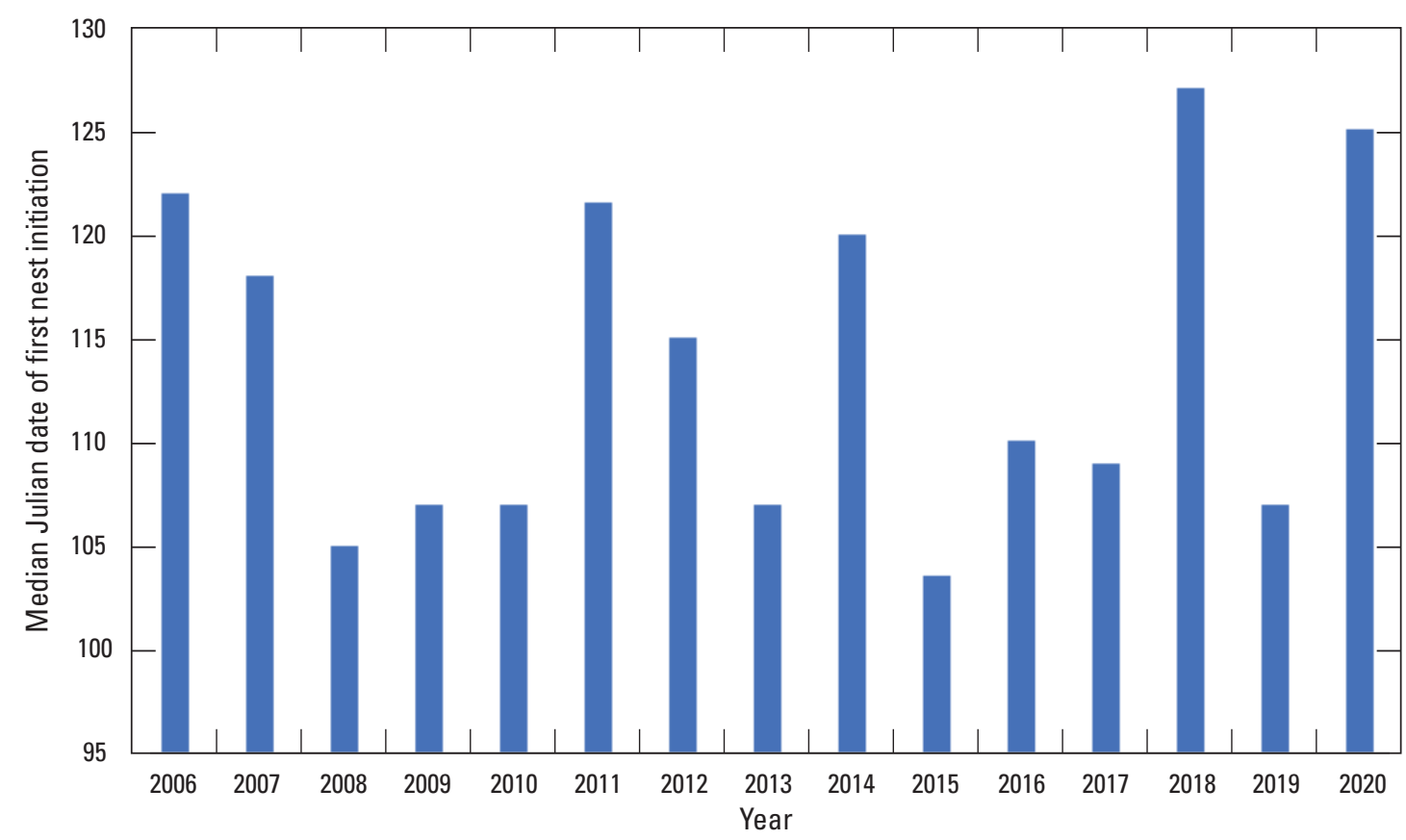

Figure 7. Nest initiation of first nests (renests excluded) at the San Luis Rey Flood Risk Management Project Area, California, from 2006 to 2020.

\section{Nest Success}

Overall, 50 percent $(69 / 138)$ of completed nests were successful (table 6). Fifty-four percent (49/90) of nests in the Channel, 40 percent (17/42) of Off-channel nests, and 50 percent (3/6) of Restoration nests fledged young. Nest success did not differ among the three sites $(P=0.36$, Fisher's exact test).

Causes of nest failure were similar between the Channel, Off-channel, and Restoration site nests. Predation was the primary source of nest failure for all sites (table 6). Predation accounted for 56 percent (23/41), 96 percent (24/25), and 67 percent (2/3) of nest failures in the Channel, Off-channel, and Restoration sites, respectively. Although most predators were believed to be birds, mammals, or snakes, possible predation by Argentine ants (Linepithema humile) was observed for one nest during the laying stage. Overall, 26 percent (23/90) of Channel nests, 57 percent (24/42) of Off-channel nests, and 33 percent (2/6) of Restoration nests were lost to predation.

Although we could attribute most nest failures to predation in 2020, there were 17 nests that failed for other or unknown reasons. Of these, four nests failed with infertile eggs, two nests were flooded, two were abandoned with eggs, one failed as a result of vegetation collapse, and eight nests failed for unknown reasons before eggs were documented.
Table 6. Fate of Least Bell's Vireo nests at the San Luis Rey Flood Risk Management Project Area, California, in 2020.

[Proportion of total completed nests shown in parentheses]

\begin{tabular}{lcccrc}
\hline \multirow{2}{*}{ Nest fate } & \multicolumn{5}{c}{ Number of nests } \\
\cline { 2 - 7 } & Channel & $\begin{array}{c}\text { Off- } \\
\text { channel }\end{array}$ & Restoration & \multicolumn{2}{c}{ Total } \\
\hline Successful & 49 & 17 & 3 & 69 & $(0.50)$ \\
\hline & 23 & 124 & 2 & 49 & $(0.36)$ \\
\hline Predation & 3 & 0 & 0 & 3 & $(0.02)$ \\
Parasitism & 15 & 1 & 1 & 17 & $(0.12)$ \\
Other/unknown & 41 & 125 & 3 & 69 & $(0.50)$ \\
\hline Failed total & 90 & 42 & 6 & 138 & $(1.00)$ \\
\hline Total completed & & & & & \\
\hline \multicolumn{1}{c}{ nests } & & &
\end{tabular}

${ }^{1}$ Includes one depredated Off-channel nest that fell outside of the Project Area. 


\section{Brown-headed Cowbird Parasitism}

We documented seven incidents of Brown-headed Cowbird parasitism in 2020. Three of these nests failed (were abandoned) as a result of the parasitism, one failed before the parasitism event, and three nests were ultimately successful following the removal of the cowbird eggs.

\section{Reproductive Success and Productivity}

Hatching and fledging success were lower in 2020 than in 2019. Overall, 69 percent of nests with eggs hatched at least one egg and 81 percent of nests with nestlings fledged at least one young (table 7), compared with 75 and 88 percent in 2019. More eggs hatched in the Channel than the Off-channel sites, but there were no other differences for any other measures of reproductive success or productivity between Channel, Off-channel and Restoration nests (table 7). There also was no difference in clutch size between Channel,
Off-channel, and Restoration. Clutch size was lower in 2020 (3.5 \pm 0.6$)$ than in $2019(3.8 \pm 0.5)$ but was similar to the 14-year average (2006-19; 3.4).

In 2020, Project Area vireos fledged $2.1 \pm 1.7$ young per pair, which was lower than in 2019 (3.8 \pm 2.1 young per pair) and lower than the 14-year average (2.6 young per pair, 2006-19; table 8; fig. 8) as well. There was no difference in productivity (the number of young fledged per pair) or in the proportion of pairs fledgling one or more young between site types. Overall, 67 percent (64/96) of pairs fledged at least one young in 2020, which was lower than productivity in 2019 (89 percent) and lower than in any other year since 2006 , with the exception of 2014 when only 30 percent of pairs successfully fledge young. In 2020, 5 percent of pairs $(5 / 96)$ successfully fledged 2 broods, which was much lower than the 30 percent $(25 / 82)$ observed in 2019 , and lower than the 14-year average of 13 percent.

Table 7. Reproductive parameters for nesting Least Bell's Vireos at the San Luis Rey Flood Risk Management Project Area, California, in 2020.

[Nests were categorized based on their locations within Channel, Off-channel, and Restoration sites rather than based on the pair's territory site category. Standard deviations presented with means. Channel includes Reaches 1, 2, 3a, 3b, and 4, excluding restoration sites. Off-channel includes Upper Pond and Whelan Mitigation, excluding restoration sites. Restoration includes Benet Restoration, College Restoration, and Whelan Restoration. Abbreviations: \pm , plus or minus; \%, percent; *, signifies significance; =, equals]

\begin{tabular}{|c|c|c|c|c|}
\hline Parameter & Channel & $\begin{array}{c}\text { Off- } \\
\text { channel }\end{array}$ & Restoration & Overall \\
\hline Nests with eggs & 79 & 38 & 6 & 123 \\
\hline Eggs laid & 246 & 120 & 19 & 385 \\
\hline Average clutch size ${ }^{1}$ & $3.5 \pm 0.5$ & $3.5 \pm 0.7$ & $3.8 \pm 0.5$ & $3.5 \pm 0.6$ \\
\hline Hatchlings & 171 & 69 & 14 & 254 \\
\hline Nests with hatchlings & 59 & 22 & 4 & 85 \\
\hline \multicolumn{5}{|c|}{ Hatching success } \\
\hline Eggs $^{2}$ & $70 \%$ & $58 \%$ & $74 \%$ & $66 \%$ \\
\hline Nests $^{3}$ & $75 \%$ & $58 \%$ & $67 \%$ & $69 \%$ \\
\hline Fledglings & 136 & 52 & 11 & 199 \\
\hline Nests with fledglings & 49 & 17 & 3 & 69 \\
\hline \multicolumn{5}{|c|}{ Fledging success } \\
\hline Hatchlings $^{4}$ & $80 \%$ & $75 \%$ & $79 \%$ & $78 \%$ \\
\hline Nests $^{5}$ & $83 \%$ & $77 \%$ & $75 \%$ & $81 \%$ \\
\hline
\end{tabular}

${ }^{1}$ Based on 59 Channel, 25 Off-channel, and 4 Restoration non-parasitized nests with a full clutch (One-way ANOVA: $F$-ratio $=0.46, P=0.63$ ).

${ }^{2}$ Percent of all eggs that hatched, among all three sites: $\boldsymbol{P}=\mathbf{0 . 0 6}$, Fisher's Exact test; Channel versus Off-channel $\boldsymbol{P}=\mathbf{0 . 0 3}$, all other comparisons not significant.

${ }^{3}$ Percent of all nests with eggs in which at least one egg hatched, among all three sites: $P=0.17$, Fisher's Exact test.

${ }^{4}$ Percent of all nestlings that fledged, among all three sites: $P=0.78$, Fisher's Exact test.

${ }^{5}$ Percent of all nests with nestlings in which at least one young fledged, among all three sites: $P=0.61$, Fisher's Exact test. 
Table 8. Productivity per pair for nesting Least Bell's Vireos at the San Luis Rey Flood Risk Management Project Area, California, in 2020. Standard deviations presented with means.

$[ \pm$, plus or minus; $\geq$, greater than or equal to; $\%$, percent; =, equals $]$

\begin{tabular}{|c|c|c|c|c|c|}
\hline Parameter & Channel & $\begin{array}{c}\text { Off- } \\
\text { channel }\end{array}$ & Restoration & Mixed & Overall \\
\hline Average number of young fledged per pair ${ }^{1}$ & $2.2 \pm 1.7$ & $1.8 \pm 1.6$ & $2.2 \pm 2.0$ & $3.0 \pm 1.4$ & $2.1 \pm 1.7$ \\
\hline Pairs fledging $\geq$ one young ${ }^{2}$ & $43(69 \%)$ & $16(59 \%)$ & $3(60 \%)$ & $2(100 \%)$ & $64(67 \%)$ \\
\hline Pairs fledging two broods ${ }^{3}$ & $5(8 \%)$ & $0(0 \%)$ & $0(0 \%)$ & $0(0 \%)$ & $5(5 \%)$ \\
\hline
\end{tabular}

${ }^{1}$ Based on 62 Channel pairs, 27 Off-channel pairs, 5 Restoration pairs, and 2 Mixed pairs whose territories were fully monitored (One-way ANOVA: $F$-ratio $=0.54, P=0.66$ ).

${ }^{2}$ Based on 62 Channel pairs, 27 Off-channel pairs, 5 Restoration pairs, and 2 Mixed pairs whose territories were fully monitored ( $P=0.64$, Fisher's Exact test).

${ }^{3}$ Based on 62 Channel pairs, 27 Off-channel pairs, 5 Restoration pairs, and 2 Mixed pairs whose territories were fully monitored $(P=0.54$, Fisher's Exact test $)$.

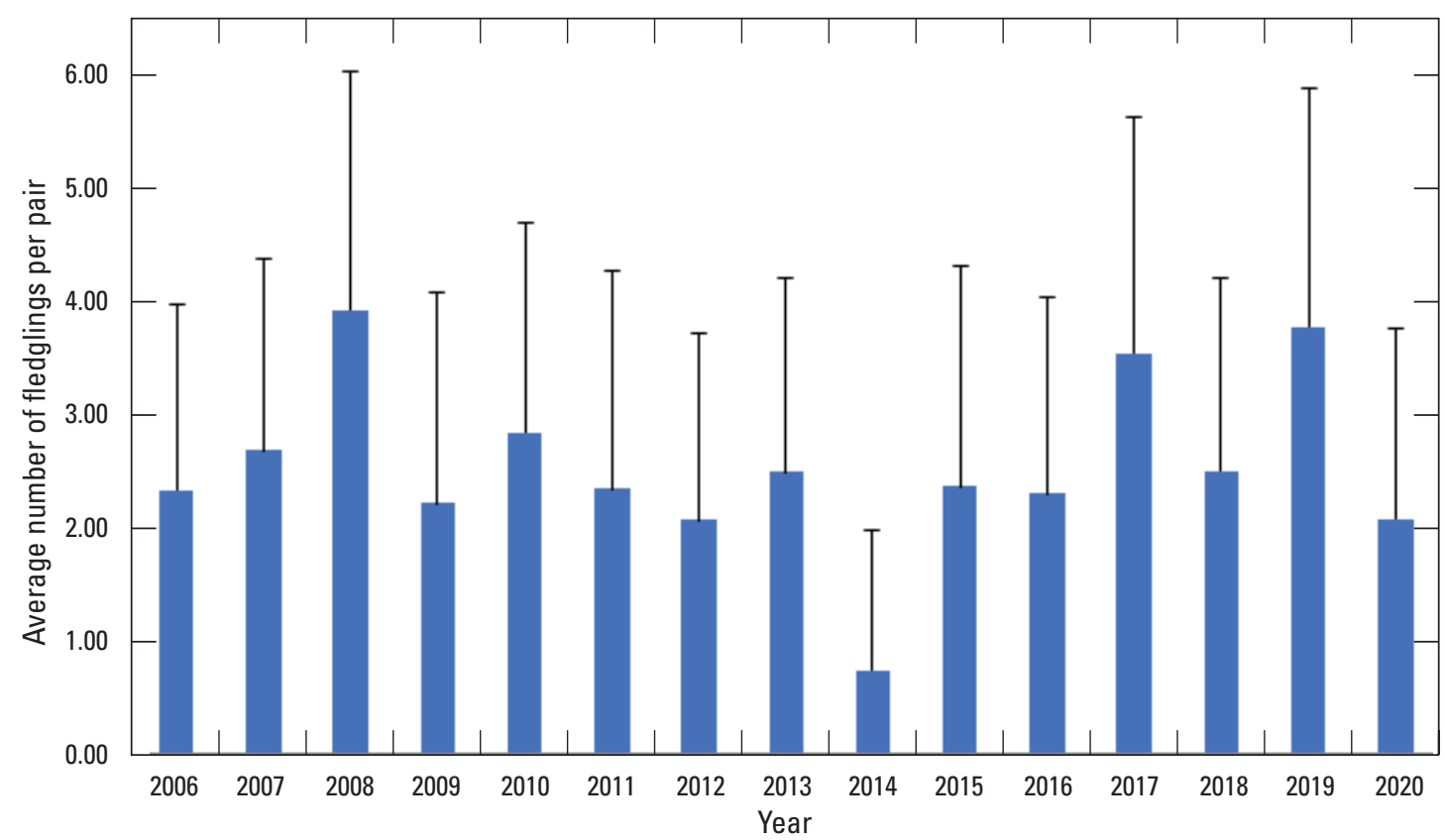

Figure 8. Average number of fledglings per pair by year at the San Luis Rey Flood Risk Management Project Area, California, from 2006 to 2020. Bars are standard deviations. 


\section{Effects of Treatment on Vireo Reproduction}

The Treatment Index for fully monitored 2020 vireo territories within the Channel that did not overlap with active restoration averaged $0.05 \pm 0.10$ ( $n=62$, range $=0-0.48$; fig. 9). In 2020, there were four fully monitored vireo territories (6 percent, 4/62) within the Channel that had no treatment. There was no effect of Treatment Index on any measures of nesting effort or productivity (number of nests, number of completed nests, or number of fledglings per pair; table 9; fig. 10).

We analyzed 2020 nest survival to determine if there was an effect of Treatment Index on DSR (within the Channel only). The best model for daily nest survival rate was the constant DSR model (table 10). There was some support for the model that included Treatment Index $\left(\Delta \mathrm{AIC}_{\mathrm{C}} \leq 2\right)$. However, an analysis of the odds ratio revealed that the 95-percent confidence interval for Treatment Index included 1, indicating that it was not a significant contributor to the model $(\beta=1.6, \mathrm{SE}=3.8$, odds ratio $=4.8,95$-percent $\mathrm{CI}=0.0-7990.4)$.

\section{Nest Survival and Habitat Use}

We investigated the effect of habitat structure at vireo nest sites on nest survival by constructing a series of models relating the vegetation cover variables to the daily nest survival rate (table 11). The best model was the model that included percent cover $1-2 \mathrm{~m}$ with the next best model including percent cover $0-1$ and $1-2 \mathrm{~m}$. Although percent cover $1-2 \mathrm{~m}$ is a significant contributor to the model, based on the low beta value of 0.01 , we can conclude that the effect of percent cover at $1-2 \mathrm{~m}$ on DSR is slight, with DSR increasing slightly as vegetation cover increases at 1-2 m (table 12).

\section{Nest Characteristics}

There were differences in nest placement between Channel, Off-channel, and Restoration nests for all four measures (table 13). Nests at Channel sites were placed higher in the vegetation than at Off-channel or Restoration sites. Host height, distance to edge of host, and distance to edge of clump were greater at Channel sites compared with Off-channel sites but were not different from Restoration sites.

Within sites, we found only one difference between successful and unsuccessful nests. At Off-channel sites, successful nests were placed higher in the vegetation than unsuccessful nests. No other differences were detected (table 13).

Red/arroyo willow and mule fat were the species most commonly selected for nesting by vireos in all three site types (76 percent of nests in the Channel, 77 percent in Off-channel sites, and 86 in Restoration sites; table 14). Vireos used a wider variety of species for nesting in Channel and Off-channel sites (7 and 10 species, respectively) compared with Restoration sites ( 3 species). Five nests were placed in exotic species in 2020.

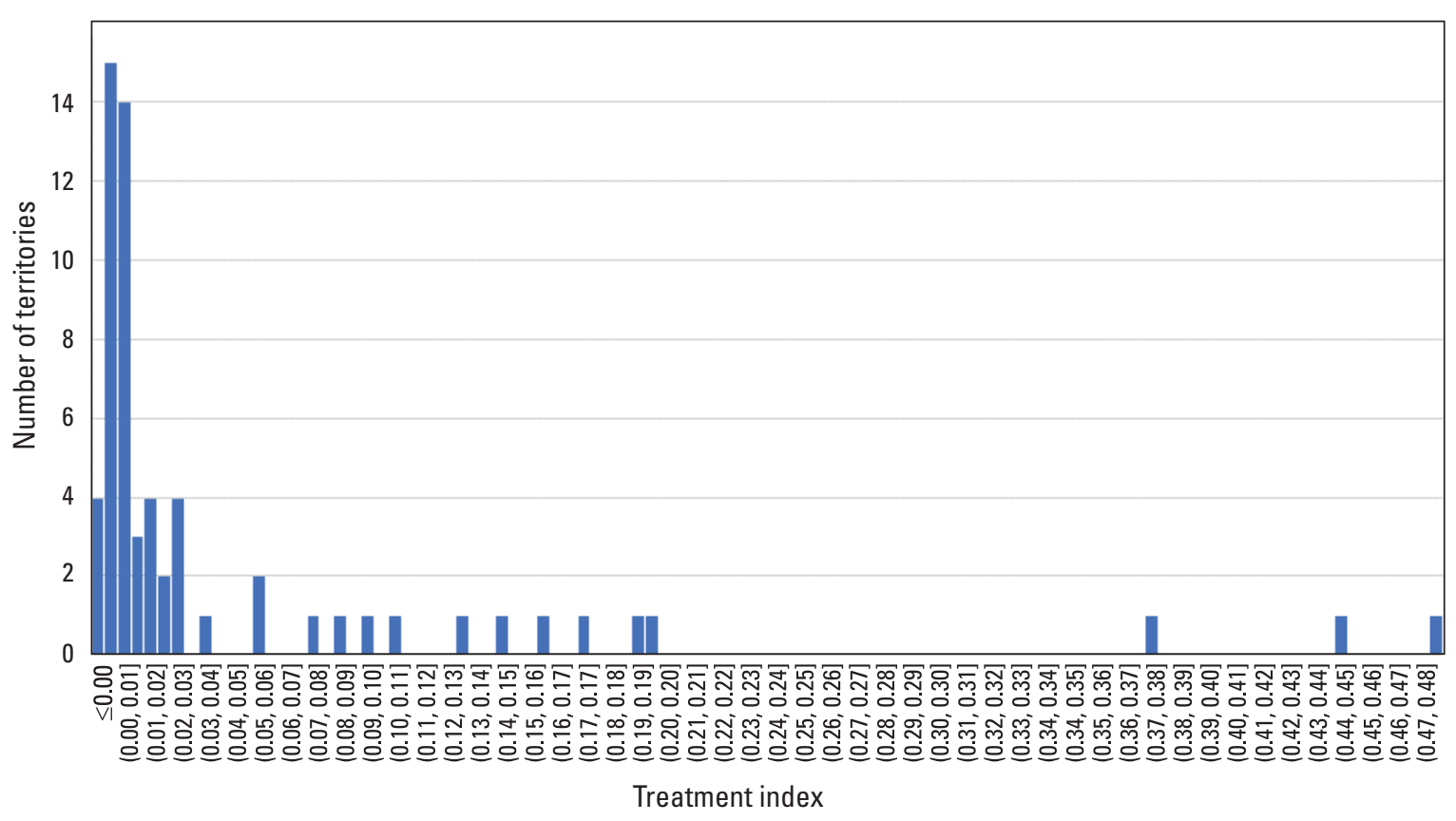

Figure 9. Number of monitored vireo territories by Treatment Index within the Channel at the San Luis Rey Flood Risk Management Project Area, California, 2020. Territories overlapping with active restoration are not included. 
Table 9. Generalized linear model (GLM) results, parameter estimate, standard error (SE), $Z$ statistic, and $P$-values for Least Bell's Vireo reproductive parameters per pair as a function of Treatment Index within the Channel at the San Luis Rey Flood Risk Management Project Area, California, 2020.

$[<$, less than $]$

\begin{tabular}{lccrc}
\hline \multicolumn{1}{c}{ Variable } & Estimate & SE & Z-value & $\boldsymbol{P}$ \\
\hline \multicolumn{5}{c}{ Number of nests } \\
\hline (Intercept) & 0.6 & 0.1 & 5.3 & $<0.01$ \\
Treatment index & -0.6 & 1.2 & -0.5 & 0.60 \\
\hline \multicolumn{5}{c}{ Number of completed nests } \\
\hline (Intercept) & 0.5 & 0.1 & 4.4 & $<0.01$ \\
Treatment index & -2.5 & 1.7 & -1.4 & 0.15 \\
\hline \multicolumn{5}{c}{} \\
\hline (Intercept) & Number of fledglings \\
Treatment index & 0.9 & 0.1 & 9.9 & $<0.01$ \\
\hline
\end{tabular}
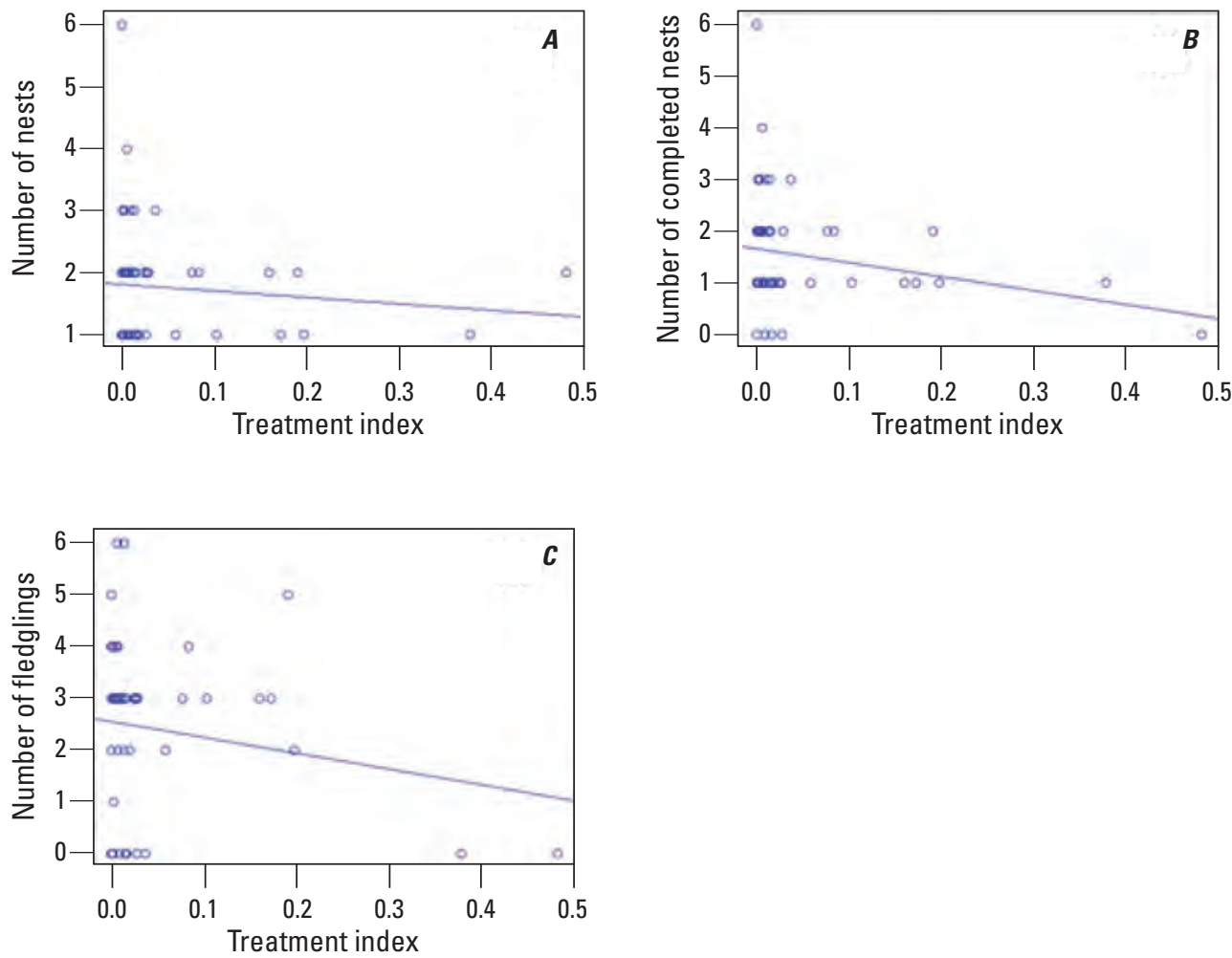

Figure 10. Effect of Treatment Index on Least Bell's Vireo reproductive parameters (per pair) at the San Luis Rey Flood Risk Management Project Area, California, 2020. $A$, Number of nests; $B$, number of completed nests; and $C$, number of fledglings per pair. Lines represent linear regression. 
Table 10. Logistic regression models for the effects of Treatment Index (within the Channel only) on daily nest survival of Least Bell's Vireos at the San Luis Rey Flood Risk Management Project Area, California, 2020.

[Models are ranked from best to worst based on Akaike's Information Criteria for small samples $\left(\mathrm{AIC}_{\mathrm{c}}\right), \Delta \mathrm{AIC}_{\mathrm{c}}$, and Akaike weights. $\mathrm{AIC}_{\mathrm{c}}$ is based on $-2 \mathrm{x} \log _{\mathrm{e}}$ likelihood and the number of parameters in the model]

\begin{tabular}{lccccc}
\hline \multicolumn{1}{c}{ Model } & Deviance & $\begin{array}{c}\text { Number of } \\
\text { parameters }\end{array}$ & AIC $_{\mathbf{c}}$ & $\mathbf{\Delta A I C}_{\mathbf{c}}$ & $\begin{array}{c}\mathbf{A l C}_{\mathbf{c}} \\
\text { weight }\end{array}$ \\
\hline Constant & 194.1 & 1 & 196.1 & 0.0 & 0.71 \\
Treatment index & 193.9 & 2 & 198.0 & 1.8 & 0.29 \\
\hline
\end{tabular}

Table 11. Logistic regression models for the effects of habitat structure on daily nest survival of Least Bell's Vireos at the San Luis Rey Flood Risk Project Area, California, from 2006 to 2020.

[Models are ranked from best to worst based on Akaike's Information Criteria for small samples $\left(\mathrm{AIC}_{\mathrm{c}}\right), \Delta \mathrm{AIC}_{\mathrm{c}}$, and Akaike weights. $\mathrm{AIC}_{\mathrm{c}}$ is based on $-2 \times \log _{\mathrm{e}}$ likelihood and the number of parameters in the model. Abbreviations: m, meter; +, plus]

\begin{tabular}{lccccc}
\hline \multicolumn{1}{c}{ Model } & Deviance & $\begin{array}{c}\text { Number of } \\
\text { parameters }\end{array}$ & AlC $_{\mathbf{c}}$ & $\boldsymbol{\Delta A I C}_{\mathbf{c}}$ & $\begin{array}{c}\mathbf{A l C}_{\mathbf{c}} \\
\text { weight }\end{array}$ \\
\hline Percent cover 1-2 m & $1,933.6$ & 2 & $1,937.6$ & 0.0 & 0.40 \\
Percent cover 0-1 m + 1-2 m & $1,933.4$ & 3 & $1,939.4$ & 1.8 & 0.16 \\
Percent cover 0-1 m & $1,936.2$ & 2 & $1,940.2$ & 2.6 & 0.11 \\
Constant DSR & $1,939.3$ & 1 & $1,941.3$ & 3.6 & 0.06 \\
Percent cover 3-4 m & $1,937.6$ & 2 & $1,941.6$ & 4.0 & 0.06 \\
Percent cover 6-7 m & $1,938.1$ & 2 & $1,942.1$ & 4.5 & 0.04 \\
Percent cover 5-6 m & $1,938.3$ & 2 & $1,942.3$ & 4.6 & 0.04 \\
Percent cover 4-5 m & $1,938.3$ & 2 & $1,942.3$ & 4.6 & 0.04 \\
Percent cover 2-3 m & $1,938.7$ & 2 & $1,942.7$ & 5.0 & 0.03 \\
Canopy height & $1,938.9$ & 2 & $1,942.9$ & 5.2 & 0.03 \\
Percent cover 7-8 m & $1,939.1$ & 2 & $1,943.1$ & 5.5 & 0.03 \\
Percent cover 2-3 m + 3-4 m +4-5 m +5-6 m +6-7 m + 7-8 m & $1,936.0$ & 7 & $1,950.0$ & 12.4 & 0.00 \\
\hline
\end{tabular}

Table 12. Parameter estimate ( $\beta$ ), standard error (SE), odds ratios and 95-percent confidence intervals (CI) for models explaining the effect of habitat structure on the daily survival rate of Least Bell's Vireos at the San Luis Rey Flood Risk Management Project Area, California, from 2006 to 2020.

[Models are in order of best-supported to least-supported. Bold indicates a significant effect. Abbreviations: m, meter; +, plus]

\begin{tabular}{lcccc}
\hline \multicolumn{1}{c}{ Effect } & $\boldsymbol{\beta}$ & SE & Odds ratio & 95-percent CI \\
\hline \multicolumn{5}{c}{ Percent cover 1-2 m } \\
\hline Intercept & 3.55 & 0.14 & 34.85 & $26.25-46.26$ \\
$1-2 \mathrm{~m}$ & 0.01 & 0.01 & 1.01 & $1.001-1.02$ \\
\hline \multicolumn{5}{c}{ Percent cover 0-1 $\mathrm{m}+1-2 \mathrm{~m}$} \\
\hline Intercept & 3.56 & 0.15 & 37.84 & $25.28-48.95$ \\
$0-1 \mathrm{~m}$ & 0.00 & 0.01 & 0.99 & $0.98-1.01$ \\
$1-2 \mathrm{~m}$ & 0.01 & 0.01 & 1.02 & $0.99-1.03$ \\
\hline
\end{tabular}


Table 13. Least Bell's Vireo nest characteristics and results of Kruskal-Wallis and Mann-Whitney U-tests comparing Channel, Off-channel, and Restoration nests, and successful versus failed nests, at the San Luis Rey Flood Risk Management Project Area, California, in 2020.

[Standard deviation presented in parentheses. Asterisks indicate a significant difference, + or - represent significant between-site differences based on Tukey HSD test. Abbreviations: N, sample size; H, Kruskal-Wallis H statistic; P, P-value; U, Mann-Whitney U statistic; m, meter; -, not applicable; <, less than]

\begin{tabular}{|c|c|c|c|c|c|c|c|c|}
\hline Nest characteristic & Channel & $\mathbf{N}$ & Off-channel & $\mathbf{N}$ & Restoration & $\mathbf{N}$ & H & $\mathbf{P}$ \\
\hline \multicolumn{9}{|c|}{ Overall } \\
\hline $\begin{array}{l}\text { Average nest height } \\
\text { (m) }\end{array}$ & $1.1(0.5)+$ & 95 & $0.8(0.3)-$ & 45 & $0.7(0.3)-$ & 7 & 13.4 & $<0.01 *$ \\
\hline $\begin{array}{l}\text { Average host height } \\
\text { (m) }\end{array}$ & $5.9(3.6)+$ & 96 & $4.2(2.6)-$ & 47 & $4.0(1.9)$ & 7 & 7.7 & $0.02 *$ \\
\hline $\begin{array}{c}\text { Average distance to } \\
\text { edge of host (m) }\end{array}$ & $1.3(1.4)+$ & 95 & $0.6(0.5)-$ & 46 & $1.0(1.3)$ & 7 & 7.8 & $0.02 *$ \\
\hline \multirow{2}{*}{$\begin{array}{l}\text { Average distance to } \\
\text { edge of clump (m) }\end{array}$} & $2.3(1.5)+$ & 95 & $1.3(1.0)-$ & 46 & $1.5(1.6)$ & 6 & 15.4 & $<0.01 *$ \\
\hline & Successful & $\mathbf{N}$ & Unsuccessful & $\mathbf{N}$ & $U$ & $\mathbf{P}$ & - & - \\
\hline \multicolumn{9}{|c|}{ Channel } \\
\hline $\begin{array}{l}\text { Average nest height } \\
\text { (m) }\end{array}$ & $1.0(0.3)$ & 49 & $1.1(0.6)$ & 46 & $1,145.0$ & 0.90 & - & - \\
\hline $\begin{array}{l}\text { Average host height } \\
\text { (m) }\end{array}$ & $6.4(3.8)$ & 49 & $5.5(3.4)$ & 47 & 988.5 & 0.23 & - & - \\
\hline $\begin{array}{c}\text { Average distance to } \\
\text { edge of host (m) }\end{array}$ & $1.3(1.2)$ & 49 & $1.3(1.5)$ & 46 & $1,050.5$ & 0.57 & - & - \\
\hline $\begin{array}{l}\text { Average distance to } \\
\text { edge of clump (m) }\end{array}$ & $2.5(1.6)$ & 48 & $2.1(1.5)$ & 47 & 938.5 & 0.16 & - & - \\
\hline \multicolumn{9}{|c|}{ Off-channel } \\
\hline $\begin{array}{l}\text { Average nest height } \\
\text { (m) }\end{array}$ & $0.9(0.3)$ & 17 & $0.8(0.3)$ & 28 & 156.5 & $0.06^{*}$ & - & - \\
\hline $\begin{array}{l}\text { Average host height } \\
\text { (m) }\end{array}$ & $3.9(2.2)$ & 17 & $4.4(2.8)$ & 30 & 276.5 & 0.64 & - & - \\
\hline $\begin{array}{c}\text { Average distance to } \\
\text { edge of host (m) }\end{array}$ & $0.5(0.4)$ & 17 & $0.7(0.5)$ & 29 & 303.5 & 0.20 & - & - \\
\hline $\begin{array}{l}\text { Average distance to } \\
\text { edge of clump (m) }\end{array}$ & $1.0(0.5)$ & 17 & $1.5(1.2)$ & 29 & 288.5 & 0.34 & - & - \\
\hline \multicolumn{9}{|c|}{ Restoration } \\
\hline $\begin{array}{l}\text { Average nest height } \\
\text { (m) }\end{array}$ & $0.9(0.4)$ & 3 & $0.6(0.2)$ & 4 & 4.0 & 0.63 & - & - \\
\hline $\begin{array}{l}\text { Average host height } \\
\text { (m) }\end{array}$ & $3.8(1.0)$ & 3 & $4.1(2.5)$ & 4 & 6.0 & 1.00 & - & - \\
\hline $\begin{array}{c}\text { Average distance to } \\
\text { edge of host }(\mathrm{m})\end{array}$ & $0.5(0.1)$ & 3 & $1.4(1.7)$ & 4 & 8.0 & 0.63 & - & - \\
\hline $\begin{array}{l}\text { Average distance to } \\
\text { edge of clump }(\mathrm{m})\end{array}$ & $0.5(0.1)$ & 3 & $2.5(1.9)$ & 3 & 6.0 & 0.70 & - & - \\
\hline
\end{tabular}

${ }^{1}$ Clump boundaries were defined where leaves or branches of neighboring plants no longer overlapped. 
Table 14. Host plant species used by Least Bell's Vireos at the San Luis Rey Flood Risk Management Project Area, California, in 2020.

[Numbers in parentheses are proportions of total nests. Abbreviation: - , not applicable]

\begin{tabular}{|c|c|c|c|c|c|c|c|c|c|}
\hline \multirow{2}{*}{ Host species } & \multicolumn{3}{|c|}{ Channel } & \multicolumn{3}{|c|}{ Off-channel } & \multicolumn{3}{|c|}{ Restoration } \\
\hline & Successful & Unsuccessful & Total & Successful & Unsuccessful & Total & Successful & Unsuccessful & Total \\
\hline $\begin{array}{l}\text { Red/arroyo } \\
\text { willow }\end{array}$ & 28 & 25 & $53(0.55)$ & 7 & 15 & $22(0.47)$ & 1 & 1 & $2(0.29)$ \\
\hline Mule fat & 11 & 9 & $20(0.21)$ & 6 & 8 & $14(0.30)$ & 2 & 2 & $4(0.57)$ \\
\hline Black willow & 6 & 5 & $11(0.11)$ & 0 & 1 & $1(0.02)$ & - & - & - \\
\hline $\begin{array}{l}\text { Poison oak } \\
\text { (Toxicodendron } \\
\text { diversilobum) }\end{array}$ & 4 & 4 & $8(0.08)$ & 0 & 1 & $1(0.02)$ & 0 & 1 & $1(0.14)$ \\
\hline $\begin{array}{l}\text { Fremont } \\
\quad \text { cottonwood }\end{array}$ & 0 & 2 & $2(0.02)$ & 0 & 1 & $1(0.02)$ & - & - & - \\
\hline Sandbar willow & 0 & 1 & $1(0.01)$ & 3 & 1 & $4(0.09)$ & - & - & - \\
\hline Black mustard & 0 & 1 & $1(0.01)$ & 0 & 1 & $1(0.02)$ & - & - & - \\
\hline Giant reed & - & - & - & 0 & 1 & $1(0.02)$ & - & - & - \\
\hline Poison hemlock & - & - & - & 0 & 1 & $1(0.02)$ & - & - & - \\
\hline $\begin{array}{l}\text { Common fig } \\
\quad \text { (Ficus carica) }\end{array}$ & - & - & - & 1 & 0 & $1(0.02)$ & - & - & - \\
\hline
\end{tabular}

\section{Banded Birds}

We determined banding status for 95 percent $(294 / 310)$ of adult vireos (162 males, 99 percent of all males and 132 females, 90 percent of all females) observed at the San Luis Rey Flood Risk Management Project Area in 2020. Ninety-three of these had been banded before the 2020 breeding season, and their identities were verified through resighting or recapture. There were 15 vireos (6 males and 9 females) that could not be identified: 3 because the band combinations could not be confirmed and 12 because they were banded with only a single numbered metal federal band as a nestling (natal), and we were unable to recapture them in 2020 (table 15; appendix 4).

Of the 93 returning adults with a known identity, 70 were banded with full color band combinations before 2020 and 23 were natal vireos recaptured and color banded in 2020. All adults (93) were originally banded at the

Project Area (table 16). Adult birds of known age ranged from 1 to 9 years old (table 16).

\section{Emigrants}

Twenty-two vireos that were originally banded in the San Luis Rey River Project Area as nestlings or adults were detected in areas outside of the Project Area in 2020 (table 15, 17; appendix 5). Eleven of these vireos were recaptured in
2020 and banded with unique color band combinations at five drainages within MCBCP (U.S. Geological Survey, unpub. data, 2020), at the middle San Luis Rey River (upstream from the Project Area; U.S. Geological Survey, unpub. data, 2020), and at the San Diego River (U.S. Geological Survey, unpub. data, 2020). One adult vireo that was originally resighted with a unique color band combination at the San Luis Rey River Project Area in 2019 was resighted at Pilgrim Creek within MCBCP in 2020.

Ten unidentified natal vireos were detected outside the San Luis Rey River Project Area in 2020. Two natal vireos were detected at two drainages within $\mathrm{MCBCP}$ (U.S. Geological Survey, unpub. data, 2020), and eight were detected at the middle San Luis Rey River, upstream from the Project Area (U.S. Geological Survey, unpub. data, 2020). Efforts to recapture and identify these individuals were unsuccessful.

\section{New Captures}

A total of 171 vireos were banded for the first time during 2020 (table 18). These newly banded birds included 28 adults that were captured and banded with a unique color combination and 143 nestlings that were banded with a single numbered dark blue metal federal band. These newly banded vireos were not included in survivorship, fidelity, or movement analyses. 
Table 15. Banding status of Least Bell's Vireos detected at the San Luis Rey Flood Risk Management Project Area, California, in 2020, and those that emigrated from the Project Area in 2020.

[Natal, natal vireos were originally banded as nestlings with a single numbered federal band. Abbreviation: -, not applicable]

\begin{tabular}{|c|c|c|c|c|c|c|c|}
\hline \multirow{2}{*}{ Banding status } & \multicolumn{3}{|c|}{ Project Area } & \multicolumn{3}{|c|}{ Emigrants } & \multirow{2}{*}{ Total } \\
\hline & Male & Female & Subtotal & Male & Female & Subtotal & \\
\hline \multicolumn{8}{|c|}{ Known-identity vireos } \\
\hline Banded prior to 2020 & 61 & 9 & 70 & - & 1 & 1 & 71 \\
\hline Natal, recaptured in 2020 & 15 & 8 & 23 & 5 & 6 & 11 & 34 \\
\hline Subtotal & 76 & 17 & 93 & 5 & 7 & 12 & 105 \\
\hline \multicolumn{8}{|c|}{ Unidentified vireos } \\
\hline Unidentified (partial resights) & 2 & 1 & 3 & - & - & - & 3 \\
\hline Natal, not recaptured & 4 & 8 & 12 & 4 & 6 & 10 & 22 \\
\hline Grand total & 82 & 26 & 108 & 9 & 13 & 22 & 130 \\
\hline
\end{tabular}

Table 16. Number of banded adult Least Bell's Vireos, by original year banded, age, and sex, at the San Luis Rey Flood Risk Management Project Area, California, in 2020.

[Year originally banded: Year banded with a single numbered metal federal band as a nestling or with a unique color band combination as an adult; Age in 2020: Exact ages determined from single numbered metal federal band observed during recapture; estimated age applies to a bird captured as an unbanded adult; Unknown: Natal vireos banded with single numbered metal federal band or identity unknown because of inadequate resight, so natal year is not known. Twelve natal vireos were seen with a single metal blue numbered band, indicating that they were originally banded at the Project Area and 3 vireos with color-combinations that could not be identified. Abbreviations: $\geq$, greater than or equal to; yr, year; —, not applicable]

\begin{tabular}{|c|c|c|c|c|}
\hline Year originally banded & Age in 2020 & Male & Female & Total \\
\hline 2011 & $9 \mathrm{yrs}$ & 0 & 1 & 1 \\
\hline \multirow{2}{*}{2013} & $\geq 8 \mathrm{yrs}$ & 2 & 0 & 2 \\
\hline & $7 \mathrm{yrs}$ & 1 & 0 & 1 \\
\hline 2014 & $\geq 7 \mathrm{yrs}$ & 2 & 0 & 2 \\
\hline \multirow{2}{*}{2015} & $\geq 6 \mathrm{yrs}$ & 2 & 0 & 2 \\
\hline & $5 \mathrm{yrs}$ & 1 & 1 & 2 \\
\hline 2016 & $4 \mathrm{yrs}$ & 3 & 2 & 5 \\
\hline \multirow{2}{*}{2017} & $\geq 4 \mathrm{yrs}$ & 3 & 1 & 4 \\
\hline & $3 \mathrm{yrs}$ & 12 & 2 & 14 \\
\hline \multirow{2}{*}{2018} & $\geq 3 \mathrm{yrs}$ & 11 & 1 & 12 \\
\hline & $2 \mathrm{yrs}$ & 5 & 2 & 7 \\
\hline \multirow{2}{*}{2019} & $\geq 2 \mathrm{yrs}$ & 21 & 0 & 21 \\
\hline & $1 \mathrm{yr}$ & 13 & 7 & 20 \\
\hline Subtotal & - & 76 & 17 & 93 \\
\hline Unknown & $\geq 1 \mathrm{yr}$ & 6 & 9 & 15 \\
\hline Total & - & 82 & 26 & 108 \\
\hline
\end{tabular}

Table 17. Number of emigrant Least Bell's Vireos detected outside of the Project Area that originated in the San Luis Rey Flood Risk Management Project Area, California, by original year banded, age, 2020 location, and sex.

[Year originally banded: Year banded with a single numbered metal federal band as a nestling or with a unique color band combination as an adult; MCBCP: Marine Corps Base Camp Pendleton; Middle San Luis Rey River: Upstream from the Project Area, between College Boulevard and Interstate 15. Abbreviations: yr, year; —, not applicable; $\geq$, greater than]

\begin{tabular}{lccccccc}
\hline & & \multicolumn{5}{c}{ 2020 Location drainage } \\
\cline { 3 - 7 } $\begin{array}{c}\text { Year } \\
\text { originally } \\
\text { banded }\end{array}$ & $\begin{array}{c}\text { Age } \\
\text { in }\end{array}$ & $\mathbf{2 0 2 0}$ & $\begin{array}{c}\text { MCBCP } \\
\text { drainages }\end{array}$ & $\begin{array}{c}\text { Middle San } \\
\text { Luis Rey River }\end{array}$ & $\begin{array}{c}\text { Other } \\
\text { drain- } \\
\text { ages }\end{array}$ & Total \\
\cline { 3 - 7 } & & Male & Female & Male & Female & Male & \\
\hline 2016 & 4 yrs & - & 11 & - & - & - & 1 \\
2017 & 3 yrs & - & 21 & - & - & - & 1 \\
2018 & 2 yrs & 21 & 11 & - & 1 & 31 & 4 \\
2019 & 1 yr & 43 & 52 & - & 1 & - & 6 \\
\hline Subtotal & & $\mathbf{4}$ & $\mathbf{5}$ & - & $\mathbf{2}$ & $\mathbf{1}$ & $\mathbf{1 2}$ \\
\hline Unknown & $\geq 1 \mathrm{yr}$ & - & 62 & 4 & 4 & - & 10 \\
\hline Total & & $\mathbf{4}$ & $\mathbf{7}$ & $\mathbf{4}$ & $\mathbf{6}$ & $\mathbf{1}$ & $\mathbf{2 2}$ \\
\hline
\end{tabular}

${ }^{1}$ Detected at Santa Margarita River.

${ }^{2}$ Detected at Pilgrim Creek.

${ }^{3}$ Detected at San Diego River.

${ }^{4}$ One detected at Pilgrim Creek, one detected at Pueblitos Canyon, and one detected at Ysidora Basin, within the Santa Margarita Watershed.

${ }^{5}$ One detected at Las Flores Creek and one detected at Santa Margarita River.

${ }^{6}$ One detected at Pilgrim Creek and one detected at Ysidora Basin, within the Santa Margarita Watershed. 
Table 18. Total number of new Least Bell's Vireos captured and banded at the San Luis Rey Flood Risk Management Project Area, California, in 2020.

[Adult: banded with unique color combinations; Nestling: Nestlings banded with a single numbered dark blue metal federal band on the left leg. Abbreviation: -, not applicable]

\begin{tabular}{lcccc}
\hline \multicolumn{1}{c}{ Age banded } & Males & Females & Unknown sex & Total \\
\hline Adult & 26 & 2 & 0 & 28 \\
Nestling & - & - & 143 & 143 \\
Total & 26 & 2 & 143 & 171 \\
\hline
\end{tabular}

\section{Survivorship, Fidelity, and Movement}

Survivorship Models-Adults Only

The best model explaining adult over-winter survivorship included effects of sex and year on adult survival (table 19). Male survivorship was higher than female survivorship and survivorship varied by year (95-percent CI of the odds ratio did not include 1; table 20). We also examined bio-year (July-June) precipitation (National Oceanic and Atmospheric Administration, 2020), but there was little support for the models that included precipitation, indicating that precipitation on the breeding grounds was not the primary driver of annual fluctuations in survivorship in this system (table 19).

We used the top model to calculate annual over-winter survivorship and the detection probabilities for adult males and adult females (table 21). Over-winter survival for females was consistently lower than for males, averaging $59 \pm 11$ percent (range of $40-71$ percent). For males, over-winter survivorship averaged $67 \pm 10$ percent (range of 49-78 percent). Detection probability was somewhat higher for males (0.89) than for females (0.79) but was high for both sexes.

\section{Survivorship Models—Adults versus First-Year Vireos}

The best model for first-year versus adult vireo survival was the model that included the effects of age and year on survival and an effect of year on detection probability (table 22). Analysis of the odds ratio showed that survival of adult vireos was significantly higher than that of first-year vireos and that survival and detection probabilities varied by year for both age classes (95-percent CI of the odds ratio did not include 1; table 23).

Average over-winter survival across all years for adults was $70 \pm 8$ percent (range of 52-82 percent) and for first-year birds, it was $17 \pm 5$ percent (range of 8-27 percent; table 24).
Table 19. Survivorship models for the effects of sex, year, and precipitation on adult survival (Phi) for Least Bell's Vireos at the San Luis Rey Flood Risk Project Area, California, from 2006 to 2020.

[The effect of sex on detection probability (p) was included in all models. Models are ranked from best to worst based on Akaike's Information Criteria for small samples $\left(\mathrm{AIC}_{\mathrm{c}}\right), \Delta \mathrm{AIC}$, and Akaike weights. $\mathrm{AIC}_{\mathrm{c}}$ is based on $-2 \mathrm{x}$ $\log _{\mathrm{e}}$ likelihood and the number of parameters in the mode. Abbreviation: +, plus]

\begin{tabular}{|c|c|c|c|c|c|}
\hline Model & Deviance & $\begin{array}{l}\text { Number } \\
\text { of } \\
\text { param- } \\
\text { eters }\end{array}$ & $\mathrm{AIC}_{\mathrm{c}}$ & $\Delta \mathrm{AIC}_{\mathrm{c}}$ & $\begin{array}{c}\mathrm{AlC}_{\mathrm{c}} \\
\text { weight }\end{array}$ \\
\hline $\begin{array}{l}\text { Phi (sex }+ \text { year }) \\
\text { p (sex) }\end{array}$ & 460.2 & 17 & $2,930.8$ & 0.0 & 0.90 \\
\hline $\begin{array}{l}\text { Phi (year) p } \\
\quad(\text { sex })\end{array}$ & 467.4 & 16 & $2,936.0$ & 5.3 & 0.06 \\
\hline $\begin{array}{l}\text { Phi }(\operatorname{sex}+ \\
\text { precipitation }) \\
\text { p }(\operatorname{sex})\end{array}$ & 491.1 & 5 & $2,937.4$ & 6.6 & 0.03 \\
\hline $\begin{array}{l}\text { Phi } \\
\qquad \text { (precipitation) } \\
\text { p (sex) }\end{array}$ & 499.8 & 4 & $2,944.1$ & 13.3 & 0.00 \\
\hline Phi (sex) p (sex) & 527.4 & 4 & $2,971.7$ & 40.9 & 0.00 \\
\hline $\begin{array}{l}\text { Phi (constant) p } \\
\quad(\operatorname{sex})\end{array}$ & 536.0 & 3 & $2,978.3$ & 47.5 & 0.00 \\
\hline
\end{tabular}

Table 20. Parameter estimate ( $\beta$ ), standard error (SE), odds ratios and 95-percent confidence intervals (CI) for the top model explaining over-winter survivorship (Phi) of adult Least Bell's Vireos at the San Luis Rey Flood Risk Project Area, California, from 2006 to 2020.

[The Intercept (reference) represents female vireos, 2006-07. All other effects values are the difference between that parameter and the Intercept. Bold indicates a significant effect. Abbreviation: +, plus]

\begin{tabular}{|c|c|c|c|c|}
\hline Effect & $\beta$ & SE & Odds ratio & 95-percent Cl \\
\hline \multicolumn{5}{|c|}{ Phi (sex + year) p (sex) } \\
\hline Intercept & 0.83 & 0.34 & 2.29 & $1.17-4.49$ \\
\hline Male & 0.36 & 0.13 & 1.43 & $1.11-1.85$ \\
\hline 2007-08 & -0.08 & 0.46 & 0.92 & $0.37-2.27$ \\
\hline 2008-09 & 0.05 & 0.39 & 1.06 & $0.49-2.29$ \\
\hline 2009-10 & -0.29 & 0.37 & 0.75 & $0.36-1.54$ \\
\hline 2010-11 & -1.01 & 0.36 & 0.36 & $0.18-0.73$ \\
\hline 2011-12 & -1.22 & 0.36 & 0.29 & $0.14-0.60$ \\
\hline $2012-13$ & -0.15 & 0.39 & 0.86 & $0.40-1.86$ \\
\hline 2013-14 & -0.20 & 0.38 & 0.82 & $0.39-1.74$ \\
\hline $2014-15$ & -0.13 & 0.39 & 0.87 & $0.41-1.86$ \\
\hline $2015-16$ & -0.62 & 0.37 & 0.54 & $0.26-1.12$ \\
\hline $2016-17$ & -0.17 & 0.40 & 0.84 & $0.39-1.83$ \\
\hline 2017-18 & -0.86 & 0.37 & 0.42 & $0.21-0.88$ \\
\hline 2018-19 & -0.49 & 0.37 & 0.61 & $0.30-1.26$ \\
\hline 2019-20 & -1.12 & 0.37 & 0.33 & $0.16-0.67$ \\
\hline
\end{tabular}


Table 21. Over-winter survivorship for adult female and adult male Least Bell's Vireos at the San Luis Rey Flood Risk Project Area, California, from 2006 to 2020.

[Survivorship and estimates were derived from the top model]

\begin{tabular}{lcc}
\hline Years & $\begin{array}{c}\text { Adult female } \\
\text { survivorship }\end{array}$ & $\begin{array}{c}\text { Adult male } \\
\text { survivorship }\end{array}$ \\
\hline $2006-07$ & 0.70 & 0.77 \\
$2007-08$ & 0.68 & 0.75 \\
$2008-09$ & 0.71 & 0.78 \\
$2009-10$ & 0.63 & 0.71 \\
$2010-11$ & 0.45 & 0.54 \\
$2011-12$ & 0.40 & 0.49 \\
$2012-13$ & 0.66 & 0.74 \\
$2013-14$ & 0.65 & 0.73 \\
$2014-15$ & 0.67 & 0.74 \\
$2015-16$ & 0.55 & 0.64 \\
$2016-17$ & 0.66 & 0.73 \\
$2017-18$ & 0.49 & 0.58 \\
$2018-19$ & 0.58 & 0.67 \\
$2019-20$ & 0.43 & 0.52 \\
\hline
\end{tabular}

Table 22. Survivorship models for the effects of age, year, and precipitation on survival (Phi) and the effect of year on detection probability (p) of Least Bell's Vireos at the San Luis Rey Flood Risk Project Area, California, from 2006 to 2020.

[Models are ranked from best to worst based on Akaike's Information Criteria for small samples $\left(\mathrm{AIC}_{\mathrm{c}}\right), \Delta \mathrm{AIC}_{\mathrm{c}}$, and Akaike weights. $\mathrm{AIC}_{\mathrm{c}}$ is based on $-2 \mathrm{x}$ $\log _{\mathrm{e}}$ likelihood and the number of parameters in the model. Abbreviation: +, plus]

\begin{tabular}{|c|c|c|c|c|c|}
\hline Model & Deviance & $\begin{array}{l}\text { Number of } \\
\text { param- } \\
\text { eters }\end{array}$ & $\mathrm{AIC}_{\mathrm{c}}$ & $\Delta \mathrm{AIC}_{\mathrm{c}}$ & $\begin{array}{c}\mathrm{AlC}_{\mathrm{c}} \\
\text { weight }\end{array}$ \\
\hline $\begin{array}{c}\text { Phi (age + } \\
\text { year) p } \\
\text { (year) }\end{array}$ & $3,350.3$ & 29 & $6,230.7$ & 0.0 & 1.00 \\
\hline $\begin{array}{c}\text { Phi (age + } \\
\text { precipi- } \\
\text { tation) p } \\
\text { (year) }\end{array}$ & $3,431.4$ & 17 & $6,287.5$ & 56.8 & 0.00 \\
\hline $\begin{array}{c}\text { Phi (age) p } \\
\quad \text { (year) }\end{array}$ & $3,439.4$ & 16 & $6,293.5$ & 62.8 & 0.00 \\
\hline $\begin{array}{c}\text { Phi (year) p } \\
\text { (year) }\end{array}$ & $4,396.1$ & 28 & $7,274.5$ & $1,043.8$ & 0.00 \\
\hline
\end{tabular}

Table 23. Parameter estimate ( $\beta$ ), standard error (SE), odds ratios and 95-percent confidence intervals (CI) for the top model explaining over-winter survivorship (Phi) of first-year versus adult Least Bell's Vireos at the San Luis Rey Flood Risk Project Area, California, from 2006 to 2020 .

[The Intercept (reference) represents first-year vireos, 2006-07. All other effects values are the difference between that parameter and the Intercept. Bold indicates a significant effect. Abbreviation: +, plus]

\begin{tabular}{lrrrc}
\hline \multicolumn{1}{c}{ Effect } & $\boldsymbol{\beta}$ & \multicolumn{1}{c}{ SE } & Odds ratio & 95-percent CI \\
\hline Intercept & -1.38 & 0.18 & 0.25 & $0.18-0.36$ \\
Adults & 2.52 & 0.09 & 12.42 & $10.48-14.72$ \\
$2007-08$ & -0.31 & 0.26 & 0.74 & $0.45-1.22$ \\
$2008-09$ & 0.40 & 0.22 & 1.49 & $0.96-2.31$ \\
$2009-10$ & -0.26 & 0.24 & 0.77 & $0.48-1.23$ \\
$2010-11$ & -0.86 & 0.24 & 0.42 & $0.26-0.67$ \\
$2011-12$ & -1.08 & 0.24 & 0.34 & $0.21-0.55$ \\
$2012-13$ & 0.10 & 0.26 & 1.11 & $0.66-1.85$ \\
$2013-14$ & -0.45 & 0.24 & 0.64 & $0.40-1.01$ \\
$2014-15$ & -0.14 & 0.26 & 0.87 & $0.52-1.46$ \\
$2015-16$ & -0.33 & 0.24 & 0.72 & $0.45-1.15$ \\
$2016-17$ & -0.23 & 0.24 & 0.79 & $0.49-1.28$ \\
$2017-18$ & 0.18 & 0.24 & 1.20 & $0.74-1.93$ \\
$2018-19$ & -0.47 & 0.25 & 0.63 & $0.38-1.03$ \\
$2019-20$ & -0.42 & 0.44 & 0.65 & $0.28-1.56$ \\
\hline
\end{tabular}

Table 24. Over-winter survivorship and detection probabilities for adult and first-year Least Bell's Vireos at the San Luis Rey Flood Risk Project Area, California, from 2006 to 2020.

[Estimates were calculated from the top model]

\begin{tabular}{cccc}
\hline Years & $\begin{array}{c}\text { Adult } \\
\text { survivorship } \\
\text { (percentage) }\end{array}$ & $\begin{array}{c}\text { First-year } \\
\text { survivorship } \\
\text { (percentage) }\end{array}$ & $\begin{array}{c}\text { Detection } \\
\text { probability } \\
\text { (percentage) }\end{array}$ \\
\hline $2006-07$ & 76 & 20 & 0.60 \\
$2007-08$ & 70 & 16 & 0.62 \\
$2008-09$ & 82 & 27 & 0.66 \\
$2009-10$ & 71 & 16 & 0.74 \\
$2010-11$ & 57 & 10 & 0.71 \\
$2011-12$ & 52 & 8 & 0.79 \\
$2012-13$ & 78 & 22 & 0.74 \\
$2013-14$ & 67 & 14 & 0.83 \\
$2014-15$ & 73 & 18 & 0.87 \\
$2015-16$ & 69 & 15 & 0.83 \\
$2016-17$ & 71 & 17 & 0.85 \\
$2017-18$ & 79 & 23 & 0.67 \\
$2018-19$ & 66 & 14 & 0.78 \\
$2019-20$ & 67 & 14 & 0.64 \\
\hline
\end{tabular}


First-year Dispersal 2020

Twenty-six first-year vireos that fledged from nests in the Project Area in 2019 were recaptured in 2020 (table 25). Of these, 20 were recaptured within the Project Area and 6 were recaptured outside of the Project Area (1 at Santa Margarita River; 1 at Pilgrim Creek; 1 at Pueblitos Canyon; 1 at Ysidora Basin; 1 at Las Flores Creek [S. Lynn, U.S. Geological Survey, unpub. data, 2020]; and 1 at the middle San Luis Rey River, upstream from the Project Area, between College Boulevard and Interstate 15 [L. Allen, U.S. Geological Survey, unpub. data, 2020]; table 25; appendix 6). Average dispersal distance by first-year vireos was $2.9 \pm 2.9$ kilometers $(\mathrm{km}$; range $0.7-5.0 \mathrm{~km}$ for males and $0.6-13.5 \mathrm{~km}$ for females). Males dispersed $2.3 \pm 1.5 \mathrm{~km}$ $(n=16)$ and females dispersed $3.8 \pm 4.2 \mathrm{~km}(n=10)$. The longest dispersal distance was $13.5 \mathrm{~km}$ by a female vireo recaptured at Las Flores Creek, MCBCP.

First-year Dispersal 2007-20

We examined the return locations of first-year vireos in 2020 and compared them to juvenile dispersal observed in previous years. From 2007 to 2012, the majority (61-86 percent) of returning first-year vireos returned to the Project Area (table 25). However, after 2012, the proportion of first-year vireos returning to the Project Area dropped to 31-57 percent, with a substantial contingent of first-year vireos (43-69 percent) dispersing to drainages on MCBCP and other sites outside the Project Area. In 2018, this trend changed with the majority of first-year vireos (68 percent) returning to the Project Area. In 2020, this trend continued with most of the first-year vireos returning to the Project Area compared to areas outside of the Project Area: 77 percent of first-year vireos that were observed in 2020 returned to the Project Area and 23 percent returned to drainages outside the Project Area (MCBCP and the middle San Luis Rey River). The majority of first-year vireos that returned to the Project Area established territories within the Channel.

\section{Adult Site Fidelity 2020}

Resighting banded birds allowed us to identify individuals that returned to the same territory they used in a previous year (within $100 \mathrm{~m}$ ) or moved to a different location. Sixty-two adult vireos (56 males and 6 females) that were identified in 2019 at the Project Area were resighted in 2020 (appendix 7). Returning adult vireos showed strong between-year fidelity to their previous territories. Of the 62 returning adults, 47 (76 percent of all adults; 45 males, 80 percent of males; 2 females, 33 percent of females) occupied a territory in 2020 that they had defended in 2019 (within $100 \mathrm{~m}$; appendix 7). Eleven vireos (18 percent of all adults; nine males, 16 percent of males; two females, 33 percent of females) detected in 2020 returned to areas next to their previous territories (within $300 \mathrm{~m}$ ). The remaining four vireos ( 6 percent of all adults; two males, 4 percent of males; two females, 33 percent of females) detected in 2020 returned to areas more than $300 \mathrm{~m}$ from their previous territories. The average distance moved by returning 2020 adult vireos was $0.1 \pm 0.5 \mathrm{~km}$, range $0.0-2.4 \mathrm{~km}(0.1 \pm 0.1 \mathrm{~km}$, range $0.0-0.8 \mathrm{~km}$ for males; $0.6 \pm 0.9 \mathrm{~km}$, range $0.0-2.4 \mathrm{~km}$ for females).

\section{Effect of Treatment on Adult Site Fidelity}

Because we are interested in the cumulative effect of vegetation treatment over the years on the movement of returning banded vireos, we performed a linear regression on the distance moved by banded vireos as a function of the expected Treatment Index for the vireos' 2019 territories (that is, the Treatment Index in 2020 if the bird had occupied exactly the same territory boundaries as in 2019). The residuals were skewed, so we log-transformed the data for analysis. We restricted our analysis to birds nesting in the Channel to avoid the confounding effects of passive habitat restoration that occurred Off-channel in 2017.

We found no effect of expected Treatment Index on distance moved between 2019 and $2020(P=0.91$, table 26).

\section{Southwestern Willow Flycatcher}

\section{Population Size and Distribution}

No Willow Flycatchers were detected within the Project Area in 2020 .

\section{Vegetation Study}

A total of 46 transects (526 sampling points) were sampled in the Project Area in 2020 (table 27; appendix 8, figs. 8.1-8.4). Seventy-one percent $(376 / 526)$ of points were in the Channel and 22 percent $(115 / 526)$ were located Off-channel in Upper Pond. The remaining 7 percent $(35 / 526)$ were in the Whelan Restoration site. The number of points per transect varied between 4 and 18. Three points were in homeless camps and were not sampled in 2020. Global Positioning System coordinates for the start and end point of each transect are provided in appendix 9.

\section{Vegetation Structure and Composition}

There was more foliage cover below $1 \mathrm{~m}$ in the Channel than in Upper Pond and Whelan Restoration (fig. 11). However, foliage cover from 1 to $3 \mathrm{~m}$ was higher at Whelan Restoration than in the Channel and Upper Pond. Above $1 \mathrm{~m}$, foliage cover was low at Upper Pond compared to the Channel and Whelan Restoration. Overall, foliage cover was low above $6 \mathrm{~m}$ but was higher in the Channel compared to Upper Pond and Whelan Restoration. Average live canopy height and maximum canopy height (including live and dead vegetation) was similar in the Channel (4.3 \pm 2.9 $\mathrm{m}$ and $4.3 \pm 2.9 \mathrm{~m}$, respectively), Upper Pond $(4.1 \pm 2.6 \mathrm{~m}$ and $4.2 \pm 2.6 \mathrm{~m}$, respectively), and Whelan Restoration $(4.4 \pm 1.9 \mathrm{~m}$ and $4.4 \pm 1.9 \mathrm{~m}$, respectively). 
Table 25. Number of first-year Least Bell's Vireos that originated at the San Luis Rey Flood Risk Management Project Area and returned to the Project Area (or returned to areas outside of the Project Area) from 2007 to 2020, by year and sex.

[Numbers in parentheses indicate the percentage of returning first-year vireos that returned to that area. Middle San Luis Rey River is upstream from the Project Area, between College Boulevard and Interstate 15. Abbreviations: \%, percent; —, not applicable]

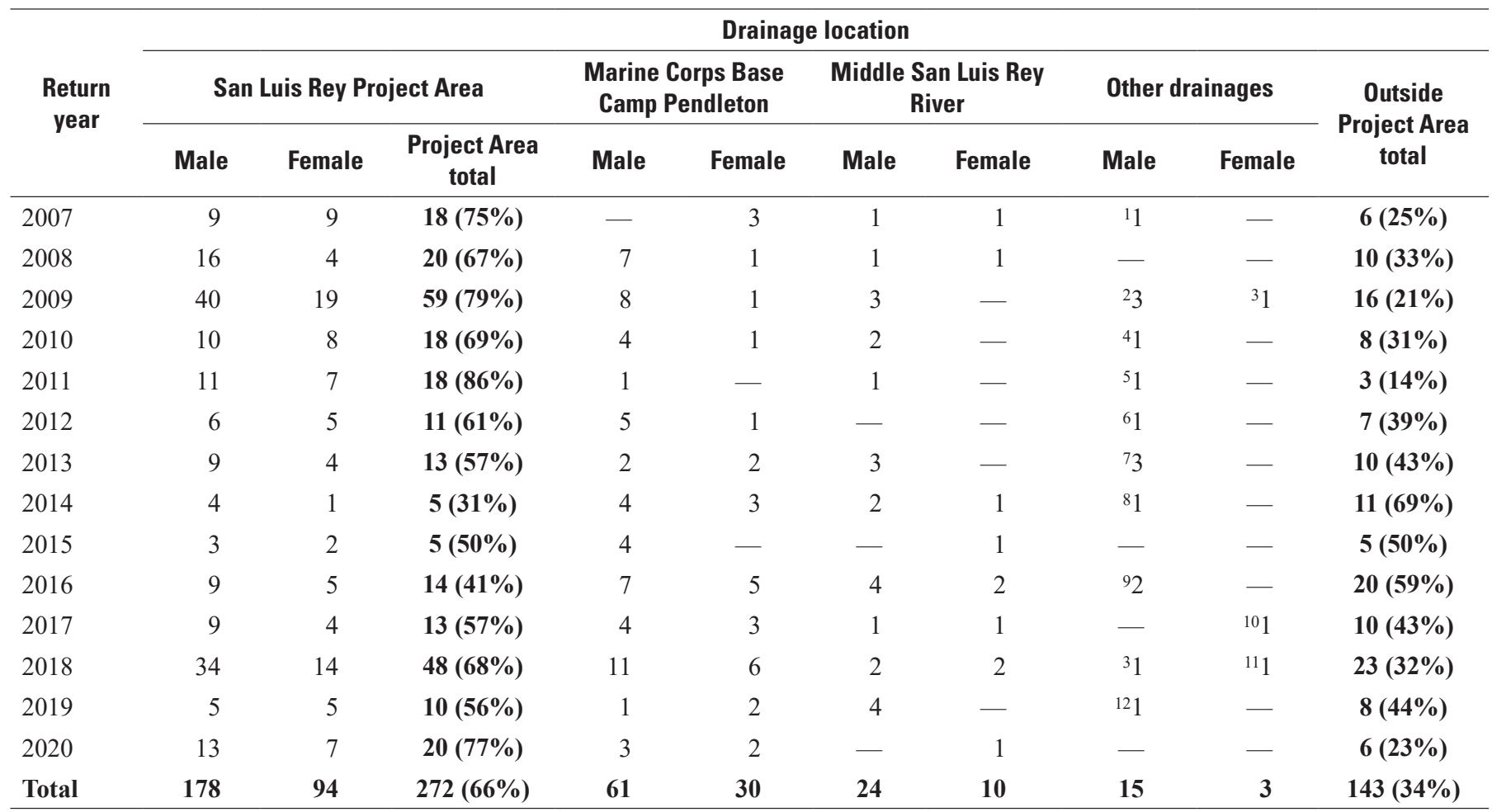

${ }^{1}$ Detected at Elanus Creek, San Diego County.

${ }^{2}$ One detected at the Santa Ana River in Orange County, one detected at San Dieguito River, and one detected at Agua Hedionda, San Diego County.

${ }^{3}$ Detected at the San Diego River, San Diego County.

${ }^{4}$ Detected at Chollas Creek, San Diego County.

${ }^{5}$ Detected at Bonita Creek, Orange County

${ }^{6}$ Detected at the San Dieguito River, San Diego County.

${ }^{7}$ One detected at the San Gabriel River, Los Angeles County, one detected at the Sweetwater River, and one detected at Moody Creek, San Diego County.

${ }^{8}$ Detected at Escondido Creek, San Diego County.

${ }^{9}$ One detected at the Tijuana River and one detected at Otay River, San Diego County.

${ }^{10}$ Detected at the Tijuana River, San Diego County.

${ }^{11}$ Detected at the upper Santa Margarita River, upstream (12 kilometers) from Marine Corps Base Camp Pendleton.

${ }^{12}$ Detected at Whelan Lake, San Diego County.

Table 26. Generalized linear model (GLM) results, parameter estimate, standard error (SE), $t$ statistic and $P$-values for banded Least Bell's Vireo movement (log-transformed) as a function of the expected Treatment Index for 2019 territories at the San Luis Rey Flood Risk Management Project Area, California, 2020.

$[<$, less than $]$

\begin{tabular}{lcccc}
\hline \multicolumn{1}{c}{ Variable } & Estimate & SE & t-value & $\boldsymbol{P}$ \\
\hline (Intercept) & 4.6 & 0.3 & 15.3 & $<0.01$ \\
Expected treatment index & 0.2 & 1.6 & 0.1 & 0.91 \\
\hline
\end{tabular}

Table 27. Number of vegetation transects and sampling points at the San Luis Rey Flood Risk Management Project Area, California, in 2020.

\begin{tabular}{lcc}
\hline \multicolumn{1}{c}{ Site type } & Transects & Sampling points \\
\hline Channel & 31 & 376 \\
Upper Pond & 13 & 115 \\
Whelan Restoration & 2 & 35 \\
Total & 46 & 526 \\
\hline
\end{tabular}




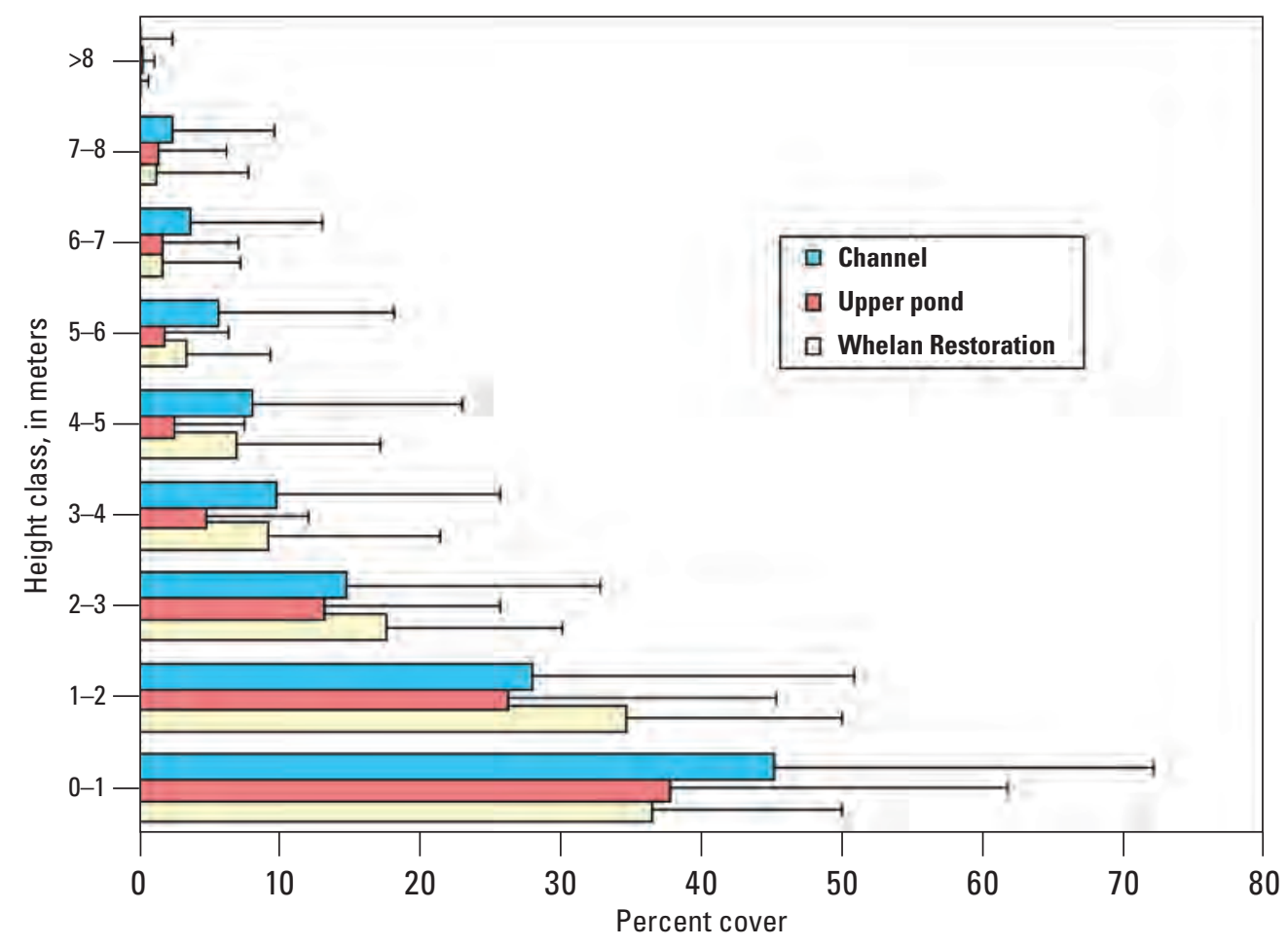

Figure 11. Average percent foliage cover by height class (meters) at the San Luis Rey Flood Risk Management Project Area, California, in 2020. Bars are standard deviations.

Vegetation composition in the Channel differed from that in Upper Pond and Whelan Restoration (fig. 12). Tree cover, dominated by red/arroyo willow, was higher in the Channel (40 percent) and Whelan Restoration (39 percent) compared to Upper Pond (20 percent). In contrast, shrub cover was substantially lower in the Channel (11 percent) than in Upper Pond (34 percent) and Whelan Restoration (34 percent). Mule fat was the dominant shrub species at all three site types. Herbaceous cover was at least 4 times greater in the Channel (28 percent) and Upper Pond (30 percent) than in Whelan Restoration (7 percent). Marsh species such as bulrush (Scirpus sp.), sedge (Carex sp.) and cattail (Typha latifolia) comprised 57 percent of the total herbaceous cover in the Channel. Exotic species cover, which included nine exotic species (see the "Vegetation Data Analysis" section), also was higher in the Channel (18 percent) and Whelan Restoration (14 percent) than at Upper Pond (4 percent). Dead, woody cover was highest in Upper Pond (12 percent), compared to the Channel ( 3 percent) and Whelan Restoration (6 percent).

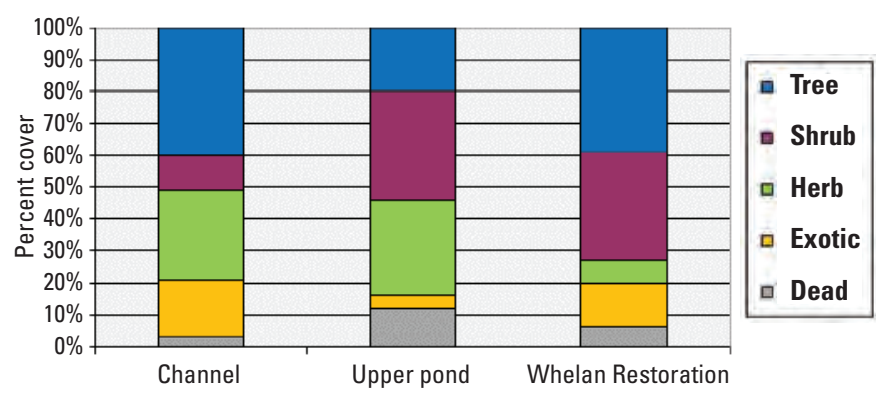

Figure 12. Percent of total cover by vegetation type at Channel, Upper Pond, and Whelan Restoration sites at the San Luis Rey Flood Risk Management Project Area, California, in 2020.

Dead vegetation in Upper Pond and Whelan Restoration was primarily red/arroyo willow, whereas most dead species in the Channel could not be identified or consisted of large debris piles from prior flooding. 


\section{Vegetation Changes from 2006 to 2020}

When we examined the cumulative effects of management activities on vegetation structure over time at the Project Area, we found significant changes from 2006 to 2020 in the Channel, Upper Pond, and Whelan Restoration (figs. 13-15). In the Channel, we found significant negative trends for all height classes above $1 \mathrm{~m}\left(1-2 \mathrm{~m}: R^{2}=0.23, P=0.04,2-3 \mathrm{~m}: R^{2}=0.40, P=0.01\right.$, 3-4 m: $R^{2}=0.26, P=0.03,4-5 \mathrm{~m}: R^{2}=0.27, P=0.03,5-6 \mathrm{~m}$ : $R^{2}=0.38, P=0.01,6-7 \mathrm{~m}: R^{2}=0.47, P=0.00,7-8 \mathrm{~m}: R^{2}=0.48$, $P=0.00$, greater than $8 \mathrm{~m}: R^{2}=0.62, P=0.00$ [fig. 13]).

Decreases were steeper from 2008 to 2013 and 2014 to 2016 than from 2006 to 2008. Since 2016, percent foliage cover increased for the lowest height classes $(0-2 \mathrm{~m})$, as herbaceous cover doubled between 2016 (13 percent) and 2019 (28 percent) and has remained high through 2020 (28 percent).
Although some increases were observed above $2 \mathrm{~m}$ after 2016 , overall percent foliage cover remained lower than levels detected before 2009 .

At Upper Pond, we found a significant negative trend from 2006 to 2020 at the $4-5 \mathrm{~m}$ height class only (4-5 m: $R^{2}=0.21, P=0.05$ [fig. 14]). Foliage cover steadily decreased from 2013 to 2020 (6 to 2 percent) at the $4-5$ m class. No other significant trends were detected at Upper Pond.

At Whelan Restoration, we found a significant negative trend for the highest height class (above $8 \mathrm{~m})$ only $\left(R^{2}=0.18\right.$, $P=0.06$ ). From 2006 to 2009 , there was a small percentage of tree cover above $8 \mathrm{~m}$ ( 2 percent), but since 2009 , there has been little to no detectable foliage cover present (fig. 15). Below $8 \mathrm{~m}$, there were no significant increasing or decreasing trends in foliage cover at Whelan Restoration.

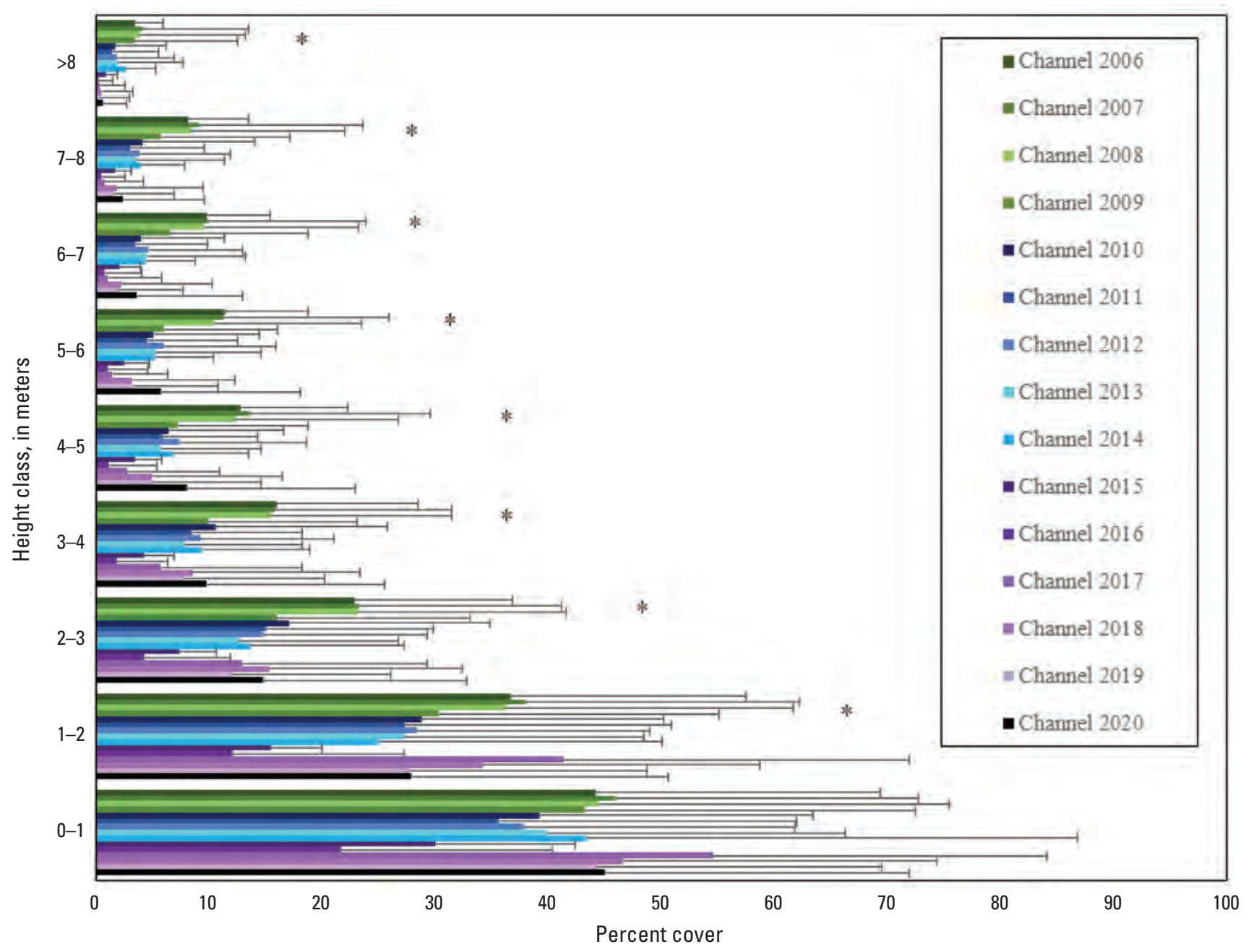

Figure 13. Average percent foliage cover by height class (meters) for the Channel at the San Luis Rey Flood Risk Management Project Area from 2006 to 2020. Bars are standard deviations. Asterisks $\left(^{*}\right)$ indicate statistically significant trends from 2006 to 2020 $(P \leq 0.10$, linear regression). 


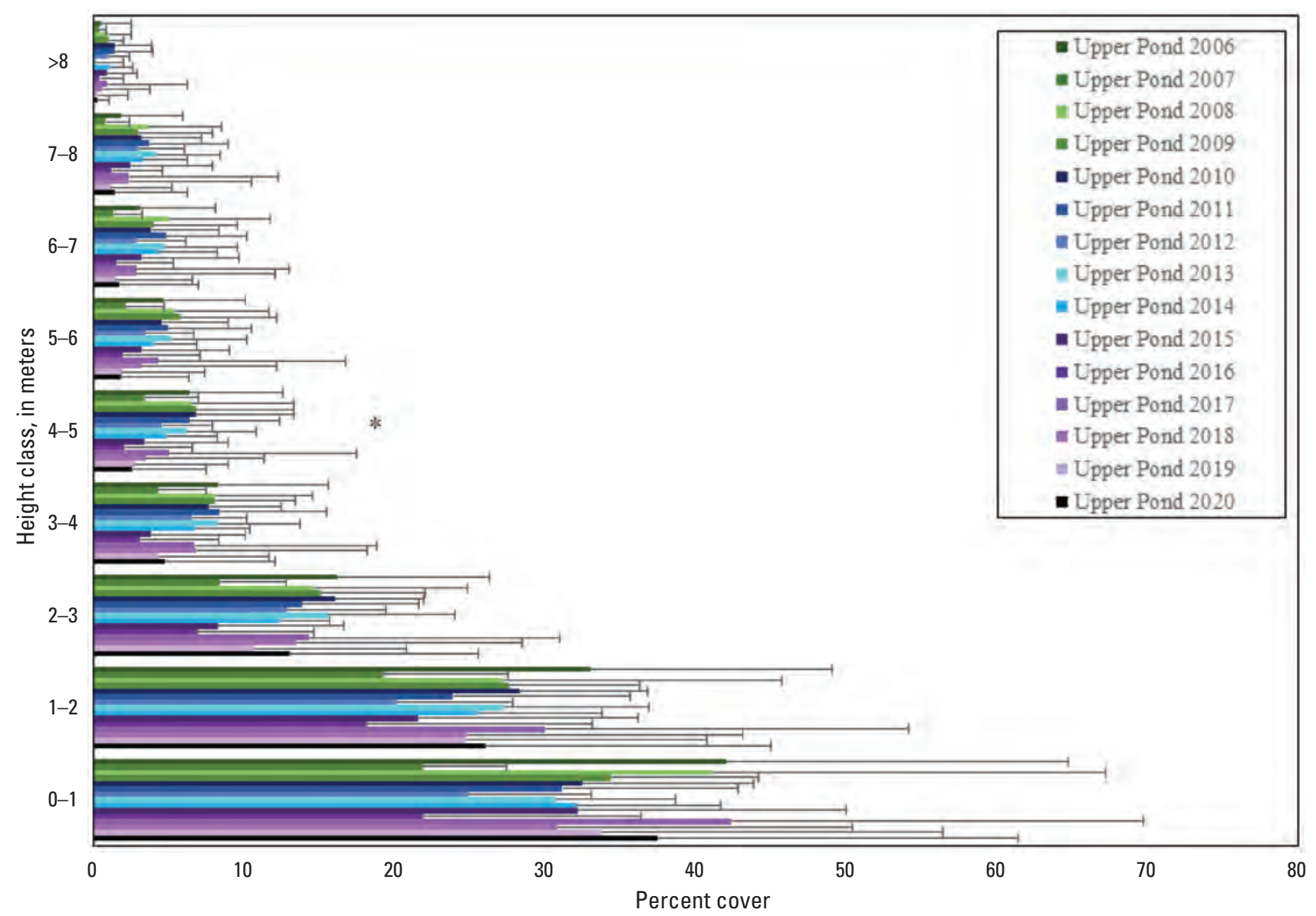

Figure 14. Average percent foliage cover by height class (meters) for Upper Pond at the San Luis Rey Flood Risk Management Project Area from 2006 to 2020. Bars are standard deviations. Asterisks (*) indicate statistically significant trends from 2006 to 2020 $(P \leq 0.10$, linear regression).

\section{Vireo Habitat Use}

We measured vegetation characteristics at 40 nest plots and 40 territory plots (320 sampling points) within the Channel and 9 nest and 9 territory plots (72 sampling points) at Upper Pond. In the Channel, foliage cover in territory plots was significantly greater than what was available at all height classes above $2 \mathrm{~m}$, indicating that vireos selected territories with thicker foliage above $2 \mathrm{~m}$. However, below $1 \mathrm{~m}$, foliage cover in territory plots was significantly lower than what was available in the Channel, indicating that vireos were selecting territories with thinner foliage in the understory. When comparing vegetation at the nest to that in the territory, we found that vireos selected nest sites randomly with regard to foliage cover below $2 \mathrm{~m}$ but were selecting nest sites with lower foliage cover above $2 \mathrm{~m}$ (fig. 16). In Upper Pond, foliage cover in territory plots was significantly greater at 2 height classes (1-2 $\mathrm{m}$ and above $8 \mathrm{~m}$ ) than what was available. Nest site selection within territories was generally non-selective, with the exception that vireos preferred sites with higher cover below $1 \mathrm{~m}$ compared to what was available in the territory (fig. 17). 


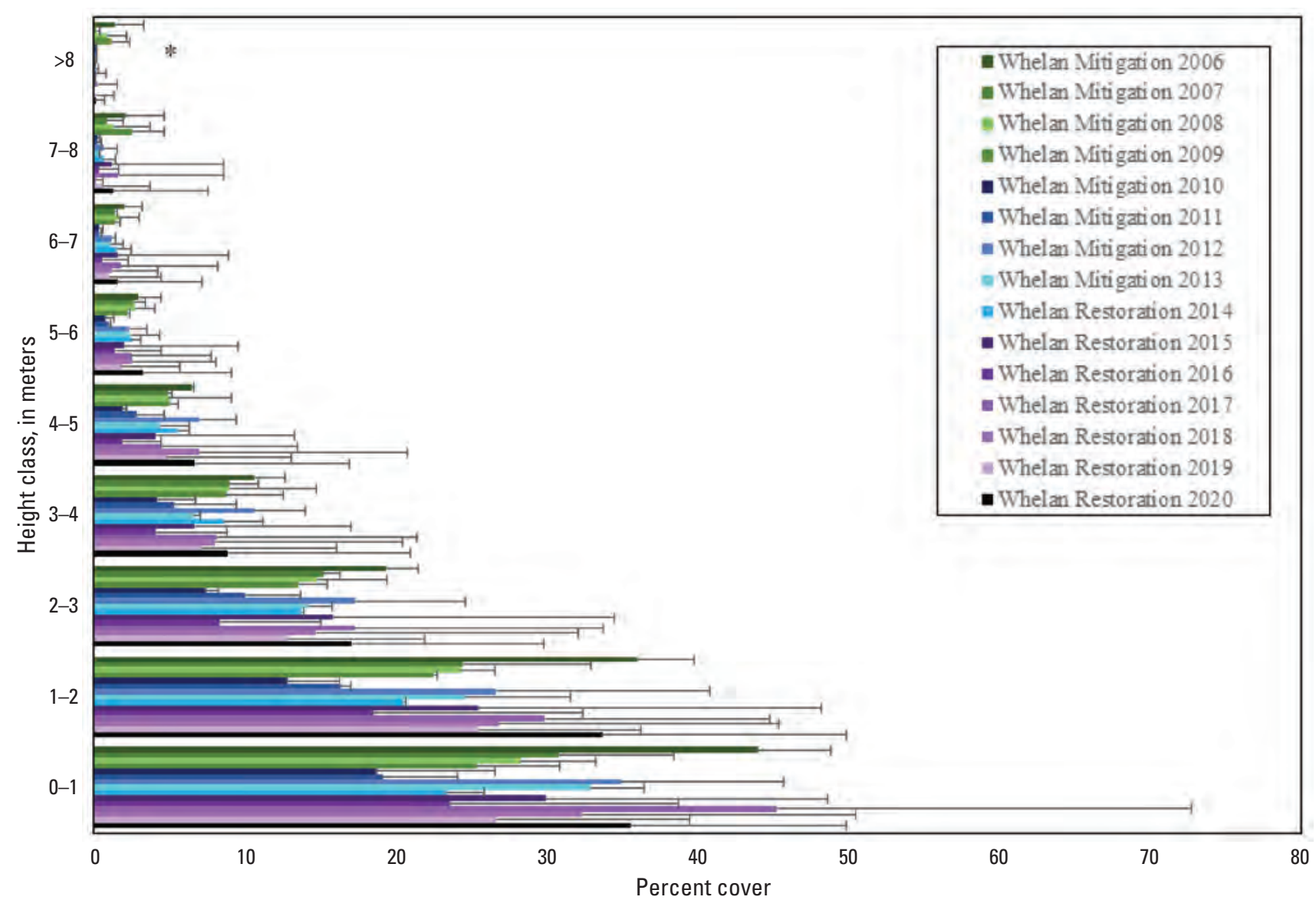

Figure 15. Average percent foliage cover by height class (meters) for Whelan Restoration and Whelan Mitigation at the San Luis Rey Flood Risk Management Project Area from 2006 to 2020. Vegetation points are the same throughout; however, Whelan Restoration was referred to as Whelan Mitigation before 2014. Bars are standard deviations. Asterisks $\left({ }^{*}\right)$ indicate statistically significant trends from 2006 to 2020 ( $P \leq 0.10$, linear regression).
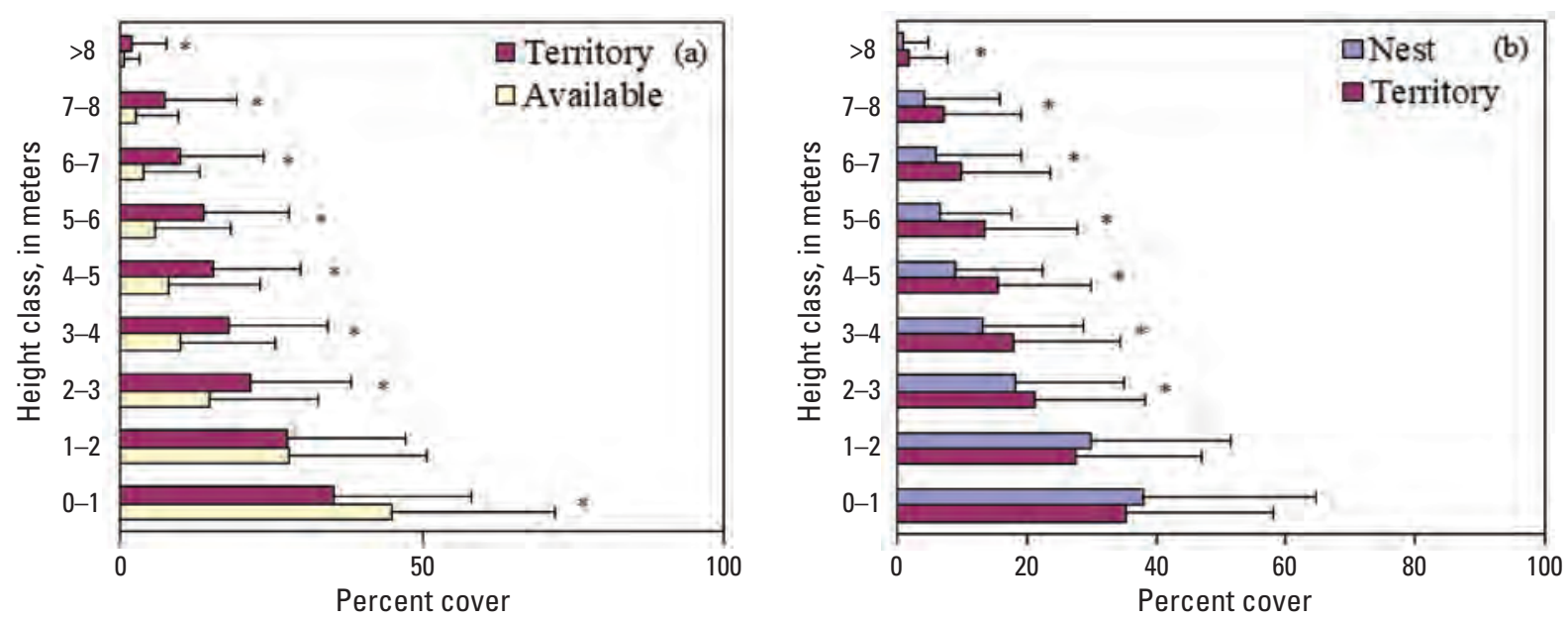

Figure 16. A, Average percent foliage cover for territory plots ( $n=40)$ compared to vegetation transects $(n=31$; shown as "Available"); and $B$, nest plots ( $n=40)$ compared to territory plots $(n=40)$ by height class in the Channel at the San Luis Rey Flood Risk Management Project Area, California, in 2020. Bars are standard deviations. Asterisks denote significant differences between plots by height class $(P \leq 0.10)$. 

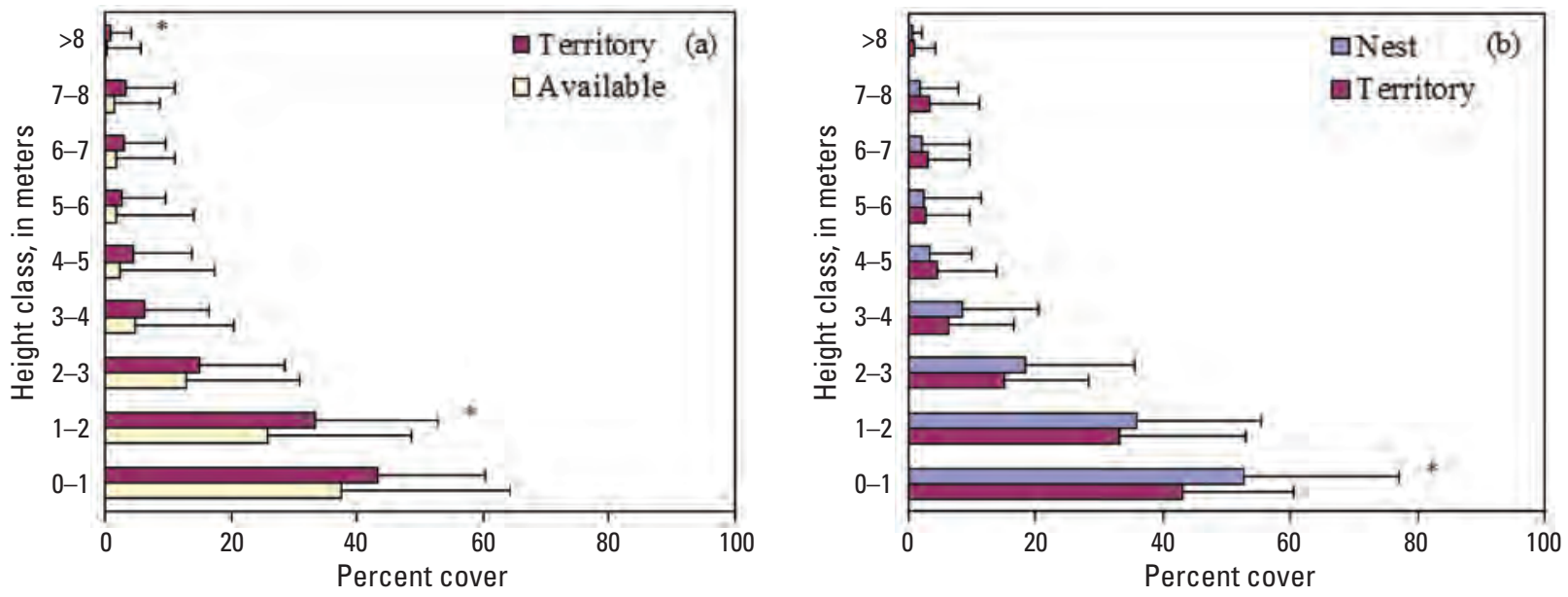

Figure 17. A, Average percent foliage cover for territory plots $(n=9)$ compared to vegetation transects $(n=13$; shown as "Available"); and $B$, nest plots ( $n=9)$ compared to territory plots $(n=9)$ by height class in the Upper Pond at the San Luis Rey Flood Risk Management Project Area, California, in 2020. Bars are standard deviations. Asterisks denote significant differences between plots by height class $(P \leq 0.10)$.

\section{Discussion}

The Least Bell's Vireo population (161 territories) at the San Luis Rey Flood Risk Management Project Area increased by 26 percent between 2019 and 2020, likely in response to high productivity in 2019. This is the second-highest recorded population since 2006 (171 territories were documented in 2009). Since surveys began in 1984, the vireo population at the Project Area grew steadily from a low of 6 territories in 1989 (Kus, 1989) to the 2009 high, likely the result of an increase in the availability of suitable riparian habitat during the 1990s, cowbird control, and high productivity of nesting pairs (Kus and Whitfield, 2005). Following this peak, vireo numbers decreased for 3 years through 2012, rebounded in 2013, then decreased for 3 years through 2016, before increasing again in 2017. In 2018, vireo populations were stable or increasing county-wide (Ferree and Clark, 2018; U.S. Geological Survey, unpub. data, 2018, Allen and Kus, 2019), whereas in 2019, we found largely decreasing populations (Ferree and Clark, 2019; U.S. Geological Survey, unpub. data, 2019), with the exception being the middle San Luis Rey, which was recovering from a fire (Allen and Kus, 2020). In 2020, vireo populations increased county-wide, with a 39-percent increase at MCBCP (U.S. Geological Survey, unpub. data, 2020), a 58-percent increase at Marine Corps Air Station Camp Pendleton (Ferree and Clark, 2020), a 78-percent increase on the Otay River (K. Ferree, San Diego Natural History Museum, written commun., 2020), and a 7-percent increase on the middle San Luis Rey River (U.S. Geological Survey, unpub. data, 2020).

Using the Treatment Index to create a quantitative snapshot in time of the vegetation removal from 2006 through the present incorporates spatial and temporal variability in vegetation structure and provides a useful approach for explaining vireos' reproductive and behavioral responses to habitat alteration. In 2020, as in 2015-19, our analyses did not reveal a relationship between the Treatment Index and reproductive parameters such as the number of fledglings produced per pair. Vireos, however, continued to show a response to vegetation removal as represented by the Treatment Index.

Since 2015, we have found that vireos have selected territories in less treated habitat and moved to avoid heavily treated areas. In 2020, the average Treatment Index of unoccupied habitat was more than 5 times greater than that of occupied habitat, indicating an avoidance of more recently treated habitat, as vireos selected territories along the Channel edges that have been less affected by mowing. However, unlike in 2016 and 2017, but similar to 2018 and 2019, we did not find an effect of territory treatment on the movement of individual banded birds between 2019 and 2020 .

Our analysis of vireo habitat supported the finding that vireos tend to avoid more recently and heavily treated sections of the river when selecting their territories. In the Channel, most of the herbaceous and exotic growth occurred in the middle where vegetation has been mowed. Vireos tended to avoid the middle of the Channel and instead limited their territories to the edges, where more mature, woody vegetation persisted. Our analysis of vireo habitat showed that vireo territories in the Channel had less total cover below $1 \mathrm{~m}$ and more cover above $2 \mathrm{~m}$ compared to what was available, which describes the strips of mature habitat along the edges of the Channel. Within territories, however, Channel vireos placed nests in areas with less cover above $2 \mathrm{~m}$ than what was present in the rest of the territory. This result is likely because many Channel vireos nested along the edge of the levee in 2020, where the canopy was shorter, resulting in less cover in the higher height classes at nest sites. The mowing of the Channel has created two distinct habitat types, 
neither of which is ideal for vireo nesting. The herbaceous middle of the Channel is too dense in the lower height classes, lacks canopy cover, and has less woody substrate that vireos prefer for nesting. The edges of the Channel are possibly becoming too mature, lacking cover diversity in the lower height classes, forcing the vireos to become more selective within their territories to find sites that are suitable for nesting, which seems to be the shrubbier edges of the Channel. In Upper Pond, which has not been subject to widespread mowing, we found that vireos were less selective with regard to territory selection.

Since mowing of the Channel began in 2005, we have documented a steady decline in total percent foliage cover at all height classes above $1 \mathrm{~m}$. Steeper annual declines in percent cover, not surprisingly, coincided with large mowing events. Herbaceous (native and exotic) cover recovered quickly after mowing and made up the bulk of the vegetation in the Channel in 2020, in contrast to Upper Pond and Whelan Restoration, which had a greater proportion of shrub cover. In general, shrub cover has not recovered in the Channel (and was limited to the Channel edges), as significant negative trends were found for all height classes. Not surprisingly, we found fewer significant negative trends from 2006 to 2020 in percent foliage cover at Upper Pond and Whelan Restoration, and instead documented annual fluctuations in both directions, likely primarily in response to environmental conditions such as variations in annual precipitation.

Nest success was lower in 2020 compared with 2019 and did not differ by site type. Vireo breeding productivity was also lower in 2020 compared with 2019 and was lower than the 14-year average. Double-brooding was also low in 2020 compared to past years. This decrease in nest success and breeding productivity across the Project Area was likely in response to lower than average precipitation during the months before breeding (January-February) coupled with unusually high precipitation once vireos had arrived on their territories in March and April (National Oceanic and Atmospheric Administration, 2020). Heavy early spring rains resulted in several nest failures and likely caused vireos to delay nest building in 2020.

Banding of vireos with unique color combinations (starting in 2006) has allowed us to estimate adult and juvenile survival rates as well as examine adult and juvenile movement between and within years at the Project Area and across drainages throughout southern California. Adult vireos continued to show strong site fidelity in 2020, with 76 percent of vireos returning to within $100 \mathrm{~m}$ of their 2019 territory. Beginning in 2012, and especially between 2014 and 2016, we detected a shift in the proportion of first-year vireos returning to the Project Area to breed, with more birds dispersing to areas outside of the Project Area. This could be attributed to a decrease in available habitat within the Project Area, which is likely a result of increased vegetation removal in 2014 and 2015 coupled with drought conditions (National Oceanic and Atmospheric Administration, 2020). However, since 2017, first-year vireos have been more likely to return to the Project Area for breeding. This increase in returning first-year vireos has coincided with increased precipitation in 3 out of the last 4 years and more moderate mowing, which has likely contributed to an increase in habitat available for new breeders in the Project Area. In 2020, 77 percent of first-year birds returned to the Project Area. The high return rate of first-year vireos in 2020 could have been inflated because survey effort on Marine Corps Base Camp Pendleton was limited in 2020.

\section{Southwestern Willow Flycatcher}

No breeding pairs of flycatchers were detected in 2020 . This was the 14th year that the Project Area has not been occupied by Willow Flycatchers since it was colonized and monitoring began in 2000 (Kus and Rourke, U.S. Geological Survey, unpub. data, 2005). It is unknown why flycatchers did not breed in the Project Area, although conditions in the historical flycatcher territories have been gradually changing since 2006 when three pairs occupied the Project Area. At Whelan Restoration in particular, large canopy trees such as red/arroyo willows and black willows have been dying, and restoration efforts are still in early phases, so this historic breeding site is likely still too sparse and open for flycatchers.

Vegetation clearing does not appear to have played a role in the decline of the flycatcher in the San Luis Rey Flood Risk Management Project Area population. More likely explanations, in addition to habitat change, include other life history factors, such as juvenile or adult mortality experienced during migration or on the wintering grounds. At nearby Marine Corps Base Camp Pendleton, the resident population of flycatchers also declined for 10 years, from 26 individuals in 2007 to 0 individuals in 2017 (S. Howell, U.S. Geological Survey, unpub. data, 2017). In 2018, a social attraction study commenced at Camp Pendleton. In 2018-19, there were three resident breeders, and two resident breeders were documented in 2020 (S. Howell, U.S. Geological Survey, unpub. data, $2018,2019,2020)$. Collection of more information is warranted for this declining species. 


\section{Conclusion}

The vireo population increased in 2020, following a highly productive year in 2019. Nest success and productivity, however, were lower in 2020, most likely in response to lower than average rainfall in the months preceding the breeding season coupled with much higher than average rainfall as vireos were establishing territories and starting nests. Although we continue to find no effect of vegetation treatment on measures of reproductive success, we do find a strong effect of treatment on vireo territory selection. For the past 6 years, we have documented an avoidance of recently treated habitat, even in years in which there was no treatment, suggesting that vireos require more than 1 year of habitat recovery between mowing events for territory selection. In addition to documenting an avoidance of recently mowed habitat, we have found that vireos have become more selective with regard to nest site selection within the Channel, which may be an indication that the strips of habitat along the Channel edges have matured to the point that they lack adequate understory favored by vireos. A gradient in habitat successional stages within the Project Area would be ideal and help to ensure that vireos will be able to continue breeding successfully in the Project Area.

\section{References Cited}

Allen, L.D., and Kus, B.E., 2019, Distribution and abundance of Least Bell's Vireos (Vireo bellii pusillus) and Southwestern Willow Flycatchers (Empidonax traillii extimus) on the Middle San Luis Rey River, San Diego, southern California_-2018 data summary: U.S. Geological Survey Data Series 1109, 12 p., https://doi.org/10.3133/ds1109.

Allen, L.D., and Kus, B.E., 2020, Distribution and abundance of Least Bell's Vireos (Vireo bellii pusillus) and Southwestern Willow Flycatchers (Empidonax traillii extimus) on the Middle San Luis Rey River, San Diego, southern California—2019 data summary: U.S. Geological Survey Data Series 1122, 11 p., https://doi.org/10.3133/ds1122.

Burnham, K.P., and Anderson, D.R., 2002, Model selection and multi-model inference-A practical information-theoretic approach 2nd ed.: New York, Springer-Verlag, $488 \mathrm{p}$.

Daubenmire, R.F., 1959, A canopy-coverage method of vegetation analysis: Northwest Science, v. 33, p. 43-64.

Dinsmore, S.J., White, G.C., and Knopf, F.L., 2002, Advanced techniques for modeling avian nest survival: Ecology, v. 83, no. 12, p. 3476-3488, https://doi.org/10.1890/00129658(2002)083[3476:ATFMAN]2.0.CO;2.
ESRI, 2016, ArcGIS Desktop—Release 10.4.1: Redlands, Calif., Environmental Systems Research Institute.

Ferree, K., and Clark, K.B., 2018, Least Bell's Vireo and Southwestern Willow Flycatcher surveys and nest monitoring at Marine Corps Air Station Camp Pendleton, California, 2018 - Final report: Prepared for Marine Corps Air Station Camp Pendleton, California, October 16, 2018.

Ferree, K., and Clark, K.B., 2019, Least Bell's Vireo and Southwestern Willow Flycatcher surveys and nest monitoring at Marine Corps Air Station Camp Pendleton, California, 2019-Final report: Prepared for Marine Corps Air Station Camp Pendleton, California, October 31, 2019.

Ferree, K., and Clark, K.B., 2020, Least Bell's Vireo and Southwestern Willow Flycatcher surveys and nest monitoring at Marine Corps Air Station Camp Pendleton, California, 2020 - Final report: Prepared for Marine Corps Air Station Camp Pendleton, California, September 3, 2020.

Franzreb, K.E., 1989, Ecology and conservation of the endangered Least Bell's Vireo: U.S. Fish and Wildlife Service, Department of the Interior, Biological Report, v. 89 , no. 1,17 p.

Gaines, D., 1988, Birds of Yosemite and the east slope: Lee Vining, California, Artemisia Press.

Garrett, K., and Dunn, J., 1981, Birds of southern CaliforniaStatus and distribution: Los Angeles, Calif., The Artisan Press.

Grinnell, J., and Miller, A., 1944, The distribution of the birds of California: Pacific Coast Avifauna, v. 27, 608 p.

Hubbard, J.P., 1987, The status of the Willow Flycatcher in New Mexico-Endangered Species Program: Santa Fe, New Mexico, New Mexico Department of Game and Fish, $29 \mathrm{p}$.

Kus, B.E., 1989, Status of the Least Bell's Vireo at the West San Luis Rey River, San Diego County, California, 1989: Prepared for the Army Corps of Engineers, Los Angeles District, $15 \mathrm{p}$.

Kus, B.E., 1998, Use of restored riparian habitat by the endangered Least Bell's Vireo (Vireo bellii pusillus): Restoration Ecology, v. 6, no. 1, p. 75-82, https://doi.org/ 10.1046/j.1526-100x.1998.06110.x.

Kus, B.E., 1999, Impacts of brown-headed Cowbird parasitism on the productivity of the endangered Least Bell's Vireo: Studies in Avian Biology, v. 18, p. 160-166.

Kus, B.E., Beck, P.P., and Wells, J.M., 2003, Southwestern Willow Flycatchers populations in southern CaliforniaDistribution, abundance, and potential for conservation: Studies in Avian Biology, v. 26, p. 12-21. 
Kus, B.E., Hopp, S.L., Johnson, R.R., and Brown, B.T., 2010, Bell's Vireo (Vireo bellii), in Poole, A.F., ed., Birds of North America online: Ithaca, Cornell Lab of Ornithology, https://doi.org/10.2173/bow.belvir.01.

Kus, B.E., and Whitfield, M.J., 2005, Parasitism, productivity, and population growth-Response of Least Bell's Vireos (Vireo bellii pusillus) and Southwestern Willow Flycatchers (Empidonax traillii extimus) to cowbird (Molothrus spp.) control: Ornithological Monographs, v. 57, no. 57, p. 16-27, https://doi.org/10.2307/40166811.

Laake, J.L., 2013, RMark-An R interface for analysis of capture-recapture data with MARK: National Oceanic and Atmospheric Administration, Alaska Fisheries Science Center, Natinal Marine Fisheries Service, AFSC Processed Report 2013-01, 25 p., https://www.afsc.noaa.gov/ Publications/ProcRpt/PR2013-01.pdf.

National Oceanic and Atmospheric Administration, 2020, Local climatological data: National Oceanic and Atmospheric Administration, https://www.ncdc.noaa.gov/.

R Core Team, 2018, R-A language and environment for statistical computing: R Foundation for Statistical Computing. Vienna Austria, http://www.R-project.org.

Remsen, J.V., Jr., 1978, Bird species of special concern in California: California Department of Fish and Game, Wildlife Management Division, Administrative Report 78-1.

Riparian Habitat Joint Venture, 2004, The riparian bird conservation plan-A strategy for reversing the decline of riparian associated birds in California, version 2.0: California Partners in Flight, http://www.prbo.org/calpif/pdfs/riparian_v-2.pdf.

Schlorff, R.W., 1990, Status review of the Willow Flycatcher (Empidonax traillii) in California: Report to the Fish and Game Commission, State of California Resources Agency.

Sogge, M.K., Ahlers, D., and Sferra, S.J., 2010, A natural history summary and survey protocol for the Southwestern Willow Flycatcher: U.S. Geological Survey Techniques and Methods 2-A10, 38 p., https://doi.org/10.3133/tm2a10.

Unitt, P., 1984, The birds of San Diego County: San Diego Society of Natural History, Memoir 13, 276 p.

Unitt, P., 1987, Empidonax traillii extimus-An endangered subspecies: Western Birds, v. 18, p. 137-162.
U.S. Fish and Wildlife Service, 1986, Endangered and threatened wildlife and plants - Determination of endangered status for the Least Bell's Vireo: Federal Register, v. 51, no. 85, p. 16474-16482.

U.S. Fish and Wildlife Service, 1993, Proposal to list the Southwestern Willow Flycatcher as an endangered species and to designate critical habitat: Federal Register, v. 58, p. 39495-39522.

U.S. Fish and Wildlife Service, 1998, Draft recovery plan for the Least Bell's Vireo: Portland, Oregon, U.S. Fish and Wildlife Service, 139 p.

U.S. Fish and Wildlife Service, 2000, Southwestern Willow Flycatcher protocol revision-U.S. Fish and Wildlife Service: Sacramento, California, California/Nevada Operations Office.

U.S. Fish and Wildlife Service, 2002, Southwestern Willow Flycatcher recovery plan: Albuquerque, New Mexico, U.S. Fish and Wildlife Service, 210 p.

U.S. Fish and Wildlife Service, 2006a, Least Bell's Vireo (Vireo bellii pusillus) 5-year review summary and evaluation: Carlsbad, California, U.S. Fish and wildlife Service, Carlsbad Fish and Wildlife Office, 24 p.

U.S. Fish and Wildlife Service, 2006b, Section 7 consultation and confirmation of a conference opinion on the operation and maintenance of the San Luis Rey River Flood Control Channel in the City of Oceanside, San Diego County, California (1-6-87-F-17R2).

Wheelock, I.G., 1912, Birds of California-An introduction to more than three hundred common birds of the state and adjacent islands: Chicago, Ill., A.C. McClurg and Company.

White, G.C., and Burnham, K.P., 1999, Program MARK - Survival estimation from populations of marked animals: Bird Study, v. 46, no. S1, p. 120-139, https://doi.org/10.1080/00063659909477239.

Whitfield, M.J., and Sogge, M.K., 1999, Range-wide impact of brown-headed Cowbird parasitism on the Southwestern Willow Flycatchers (Empidonax traillii extimus): Studies in Avian Biology, v. 18, p. 182-190.

Willett, G., 1933, A revised list of the birds of southwestern California: Pacific Coast Avifauna, no. 21, 204 p. 


\section{Appendix 1. Timeline and Description of Vegetation Treatments at the San Luis Rey Flood Risk Management Project Area, California, 2005-20}

This appendix describes the type, extent, and location of all of the vegetation treatment that has occurred in the Project Area from 2005 through 2020 .

Table 1.1. Timeline and description of vegetation treatments at the San Luis Rey Flood Risk Management Project Area, California, 2005-20.

[ha, hectare; m, meter; ft, foot; km, kilometer; —, not applicable; GPS, Global Positioning System]

\begin{tabular}{|c|c|c|c|c|c|}
\hline Date & Vegetation treatment & $\begin{array}{c}\text { Vegetation } \\
\text { management }\end{array}$ & Treatment location & $\begin{array}{l}\text { Area [ha } \\
\text { (acres)] }\end{array}$ & Comments \\
\hline \multicolumn{6}{|c|}{2006 Least Bell's Vireo breeding season (April-July) } \\
\hline
\end{tabular}

2007 Least Bell's Vireo breeding season (April-July)

\begin{tabular}{|c|c|c|c|c|c|}
\hline October 2006 & Herbicide treatment & $\begin{array}{l}\text { Giant reed sprayed } \\
\text { with herbicide. }\end{array}$ & $\begin{array}{l}\text { Reach } 4 \text { (below } \\
\text { College Boulevard) }\end{array}$ & $0.4(1.0)$ & $\begin{array}{l}\text { This spraying was an } \\
\text { experimental effort to } \\
\text { see if the herbicide after } \\
\text { mowing approach would be } \\
\text { effective. }\end{array}$ \\
\hline
\end{tabular}

\begin{tabular}{|c|c|c|c|c|c|}
\hline \multicolumn{6}{|c|}{2008 Least Bell's Vireo breeding season (April-July) } \\
\hline $\begin{array}{l}\text { November- } \\
\text { December } 2007\end{array}$ & Herbicide treatment & $\begin{array}{l}\text { Giant reed sprayed } \\
\text { with herbicide. }\end{array}$ & $\begin{array}{l}\text { Reach } 1 \text { (Benet Road } \\
\text { to } 1-5 \text { and south of } \\
\text { main river channel) }\end{array}$ & $11.9(29.4)$ & - \\
\hline $\begin{array}{l}\text { February- } \\
\quad \text { March } 2008\end{array}$ & Vegetation removal & $\begin{array}{l}\text { First Phase } 1^{2} \text { mowing, } \\
\text { not completed. }\end{array}$ & Reach 1 & $6.5(16.1)$ & $\begin{array}{l}\text { Only } 7 \text { days of mowing } \\
\text { completed before rains } \\
\text { and vireo breeding season } \\
\text { began. }\end{array}$ \\
\hline
\end{tabular}

2009 Least Bell's Vireo breeding season (April-July)

\begin{tabular}{|c|c|c|c|c|c|}
\hline July 2008 & Herbicide treatment & Pepperweed sprayed. & $\begin{array}{l}\text { Reach } 1 \text { (downstream } \\
\text { from Benet Road) }\end{array}$ & $0.08(0.2)$ & - \\
\hline $\begin{array}{l}\text { September- } \\
\text { December } 2008\end{array}$ & Vegetation removal & First Phase 1 mowing. & Reaches 2-4 & $37.9(93.7)$ & $\begin{array}{l}\text { Phase } 1 \text { mowing continued } \\
\text { after vireo breeding season. }\end{array}$ \\
\hline $\begin{array}{l}\text { September- } \\
\text { October } 2008\end{array}$ & $\begin{array}{l}\text { Giant reed removal } \\
\text { and herbicide } \\
\text { treatment }\end{array}$ & $\begin{array}{l}\text { Re-treatment of giant } \\
\text { reed sprayed in } 2005 .\end{array}$ & Reaches 2-4 & $2.3(5.7)$ & $\begin{array}{l}\text { Extensive mowing and } \\
\text { chemical re-treatment of } \\
\text { some giant reed areas that } \\
\text { had been targeted in } 2005 \\
\text { was conducted from Benet } \\
\text { Road to College Boulevard. } \\
\text { This completed the initial } \\
\text { clearing of Phase } 1 .\end{array}$ \\
\hline
\end{tabular}


Table 1.1. Timeline and description of vegetation treatments at the San Luis Rey Flood Risk Management Project Area, California, 2005-20.-Continued

[ha, hectare; m, meter; ft, foot; km, kilometer; —, not applicable; GPS, Global Positioning System]

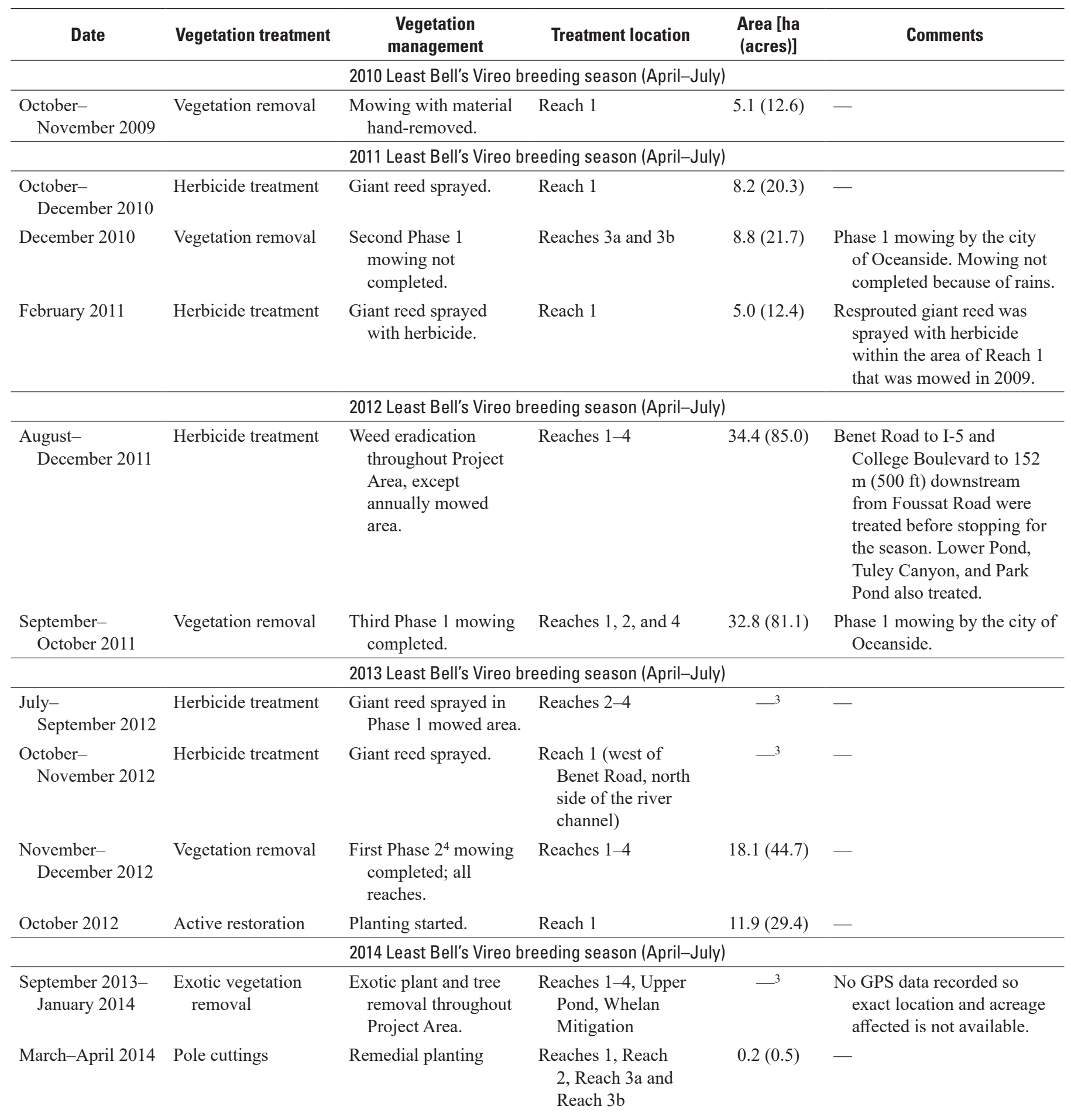


Table 1.1. Timeline and description of vegetation treatments at the San Luis Rey Flood Risk Management Project Area, California, 2005-20.-Continued

[ha, hectare; m, meter; ft, foot; km, kilometer; —, not applicable; GPS, Global Positioning System]

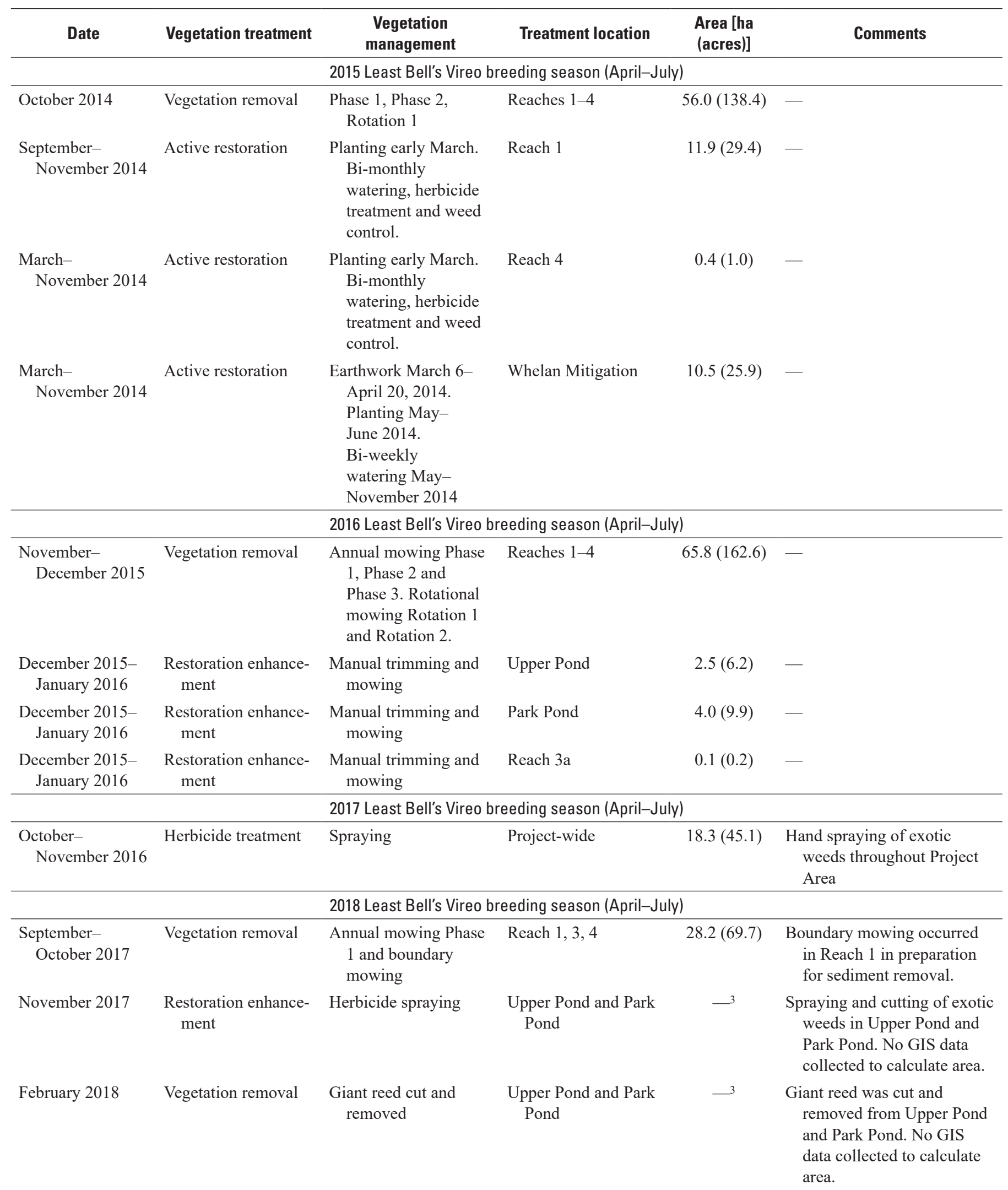


Table 1.1. Timeline and description of vegetation treatments at the San Luis Rey Flood Risk Management Project Area, California, 2005-20.-Continued

[ha, hectare; m, meter; ft, foot; km, kilometer; —, not applicable; GPS, Global Positioning System]

\begin{tabular}{|c|c|c|c|c|c|}
\hline Date & Vegetation treatment & $\begin{array}{c}\text { Vegetation } \\
\text { management }\end{array}$ & Treatment location & $\begin{array}{l}\text { Area [ha } \\
\text { (acres)] }\end{array}$ & Comments \\
\hline \multicolumn{6}{|c|}{2019 Least Bell's Vireo breeding season (April-July) } \\
\hline April 2018 & Herbicide spraying & Weed eradication & $\begin{array}{l}\text { Upper Pond and Park } \\
\text { Pond }\end{array}$ & -3 & $\begin{array}{l}\text { Herbicide applied to exotic } \\
\text { weeds around pole plant- } \\
\text { ings in Upper Pond and } \\
\text { Park Pond. No GIS data } \\
\text { collected to calculate area. }\end{array}$ \\
\hline \multicolumn{6}{|c|}{2020 Least Bell's Vireo breeding season (April-July) } \\
\hline $\begin{array}{l}\text { November- } \\
\text { December } 2019\end{array}$ & Vegetation removal & $\begin{array}{l}\text { Annual mowing Phase } \\
1 \text { and Phase } 2\end{array}$ & Reaches $1-4$ & $31.2(77.2)$ & - \\
\hline
\end{tabular}

${ }^{1}$ Risk reduction was implemented in 2005 to reduce the risk of flooding during the 2006 rainy season.

${ }^{2}$ Phase 1 mowing was the first phase of the San Luis Rey Flood Risk Management Project to remove vegetation from the San Luis Rey River flood control channel to reduce the risk of flooding.

${ }^{3}$ Acreage not available.

${ }^{4}$ Phase 2 mowing includes mowing associated with maintaining the Phase 1 mowed area. 


\section{Appendix 2. Locations of Least Bell's Vireo Territories and Completed Nests at the San Luis Rey Flood Risk Management Project Area, California, 2020}

Maps showing the location of all Least Bell's Vireo territories and completed nests within the Project Area.

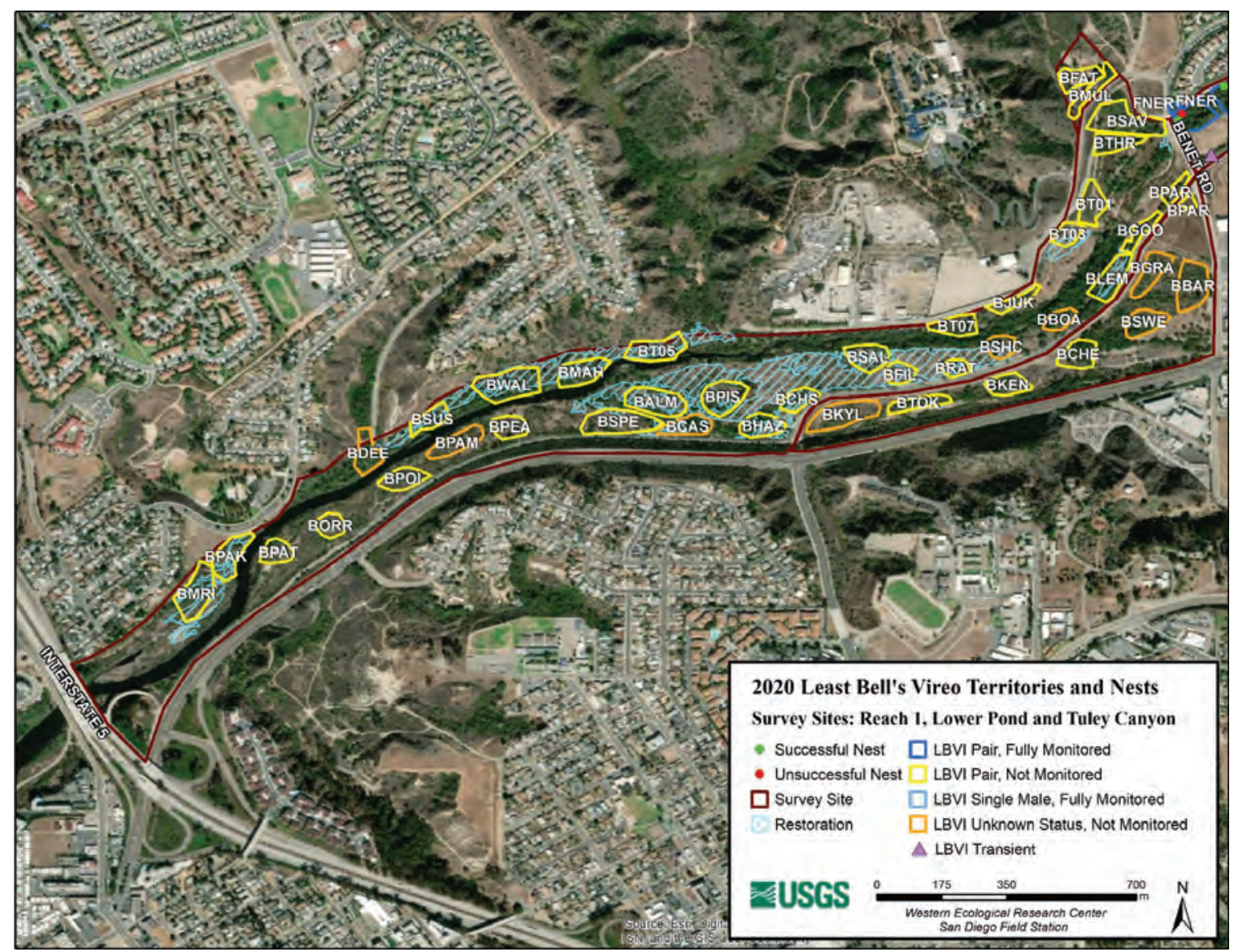

Map image is the intellectual property of Esri and is used herein under license. Copyright $(\odot) 2020$ Esri and its licensors. All rights reserved.

Figure 2.1. Locations of least Bell's vireo territories in the Reach 1, Lower Pond, and Tuley Canyon survey sites at the San Luis Rey Flood Risk Management Project Area, California, in 2020. 


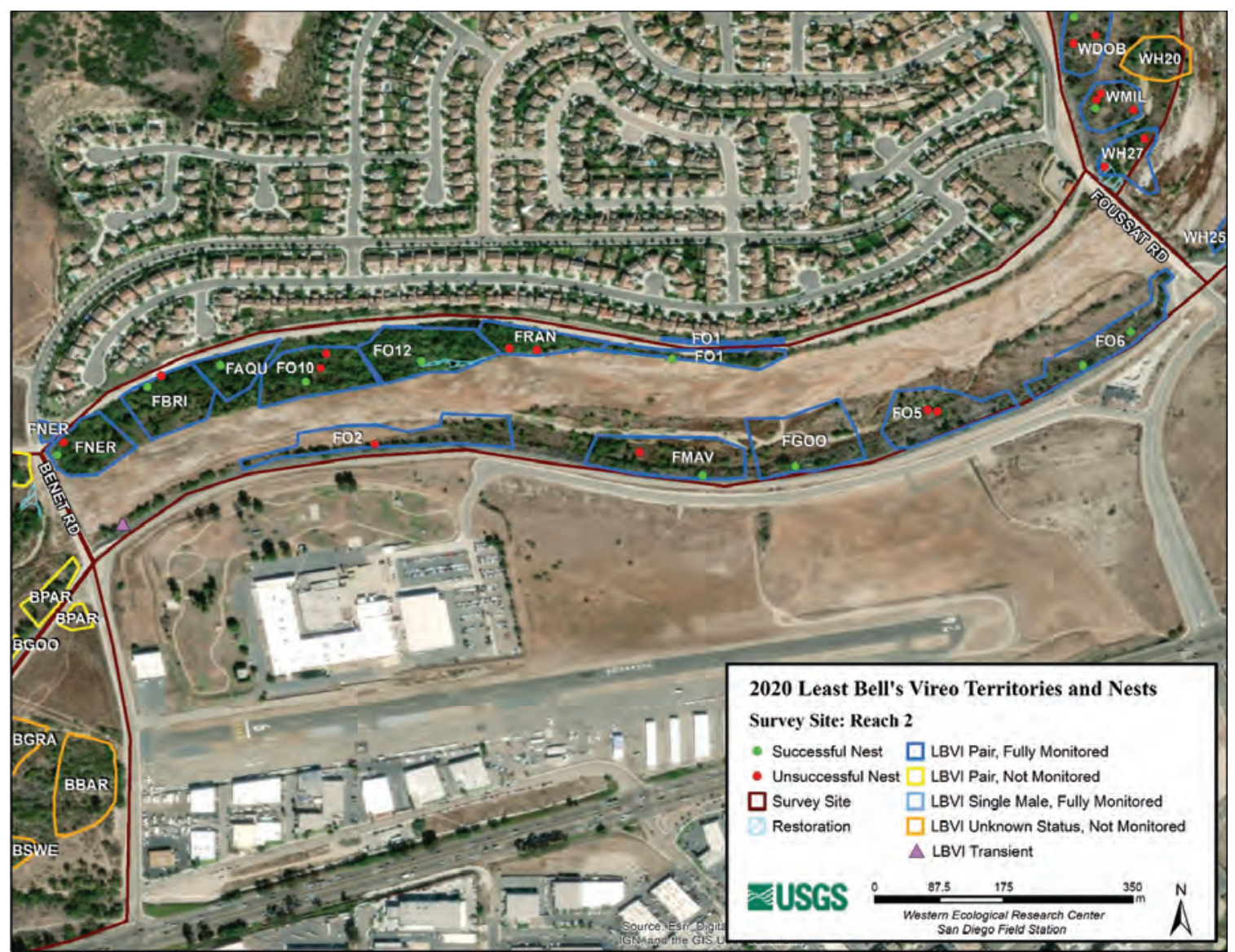

Map image is the intellectual property of Esri and is used herein under license.

Copyright ( $(2020$ Esri and its licensors. All rights reserved.

Figure 2.2. Locations of Least Bell's Vireo territories and nests in the Reach 2 survey site at the San Luis Rey Flood Risk Management Project Area, California, in 2020. 


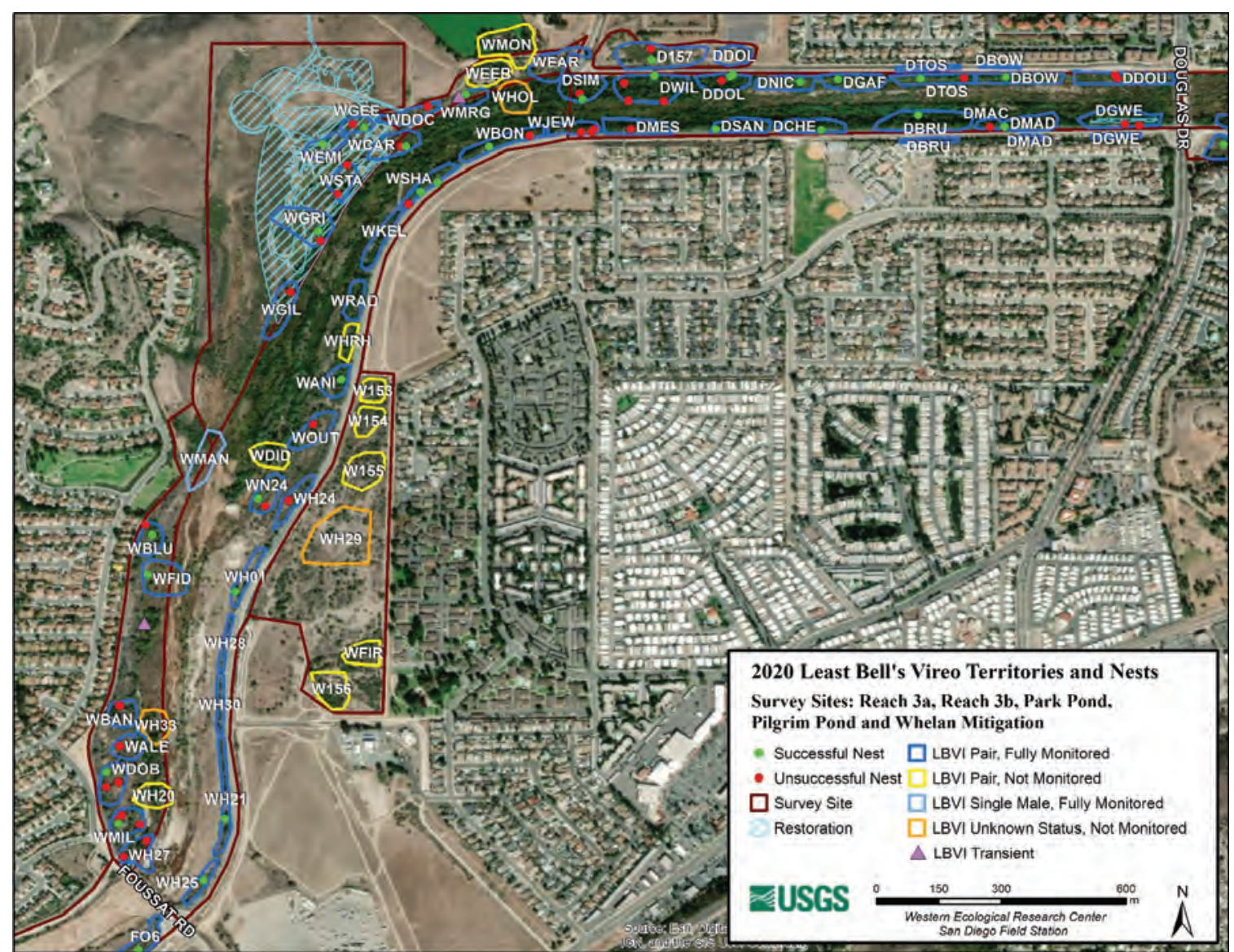

Map image is the intellectual property of Esri and is used herein under license. Copyright (C) 2020 Esri and its licensors. All rights reserved.

Figure 2.3. Locations of Least Bell's Vireo territories and nests in the Reach 3a, Reach 3b, Park Pond, Pilgrim Pond, and Whelan Mitigation survey sites at the San Luis Rey Flood Risk Management Project Area, California, in 2020. 


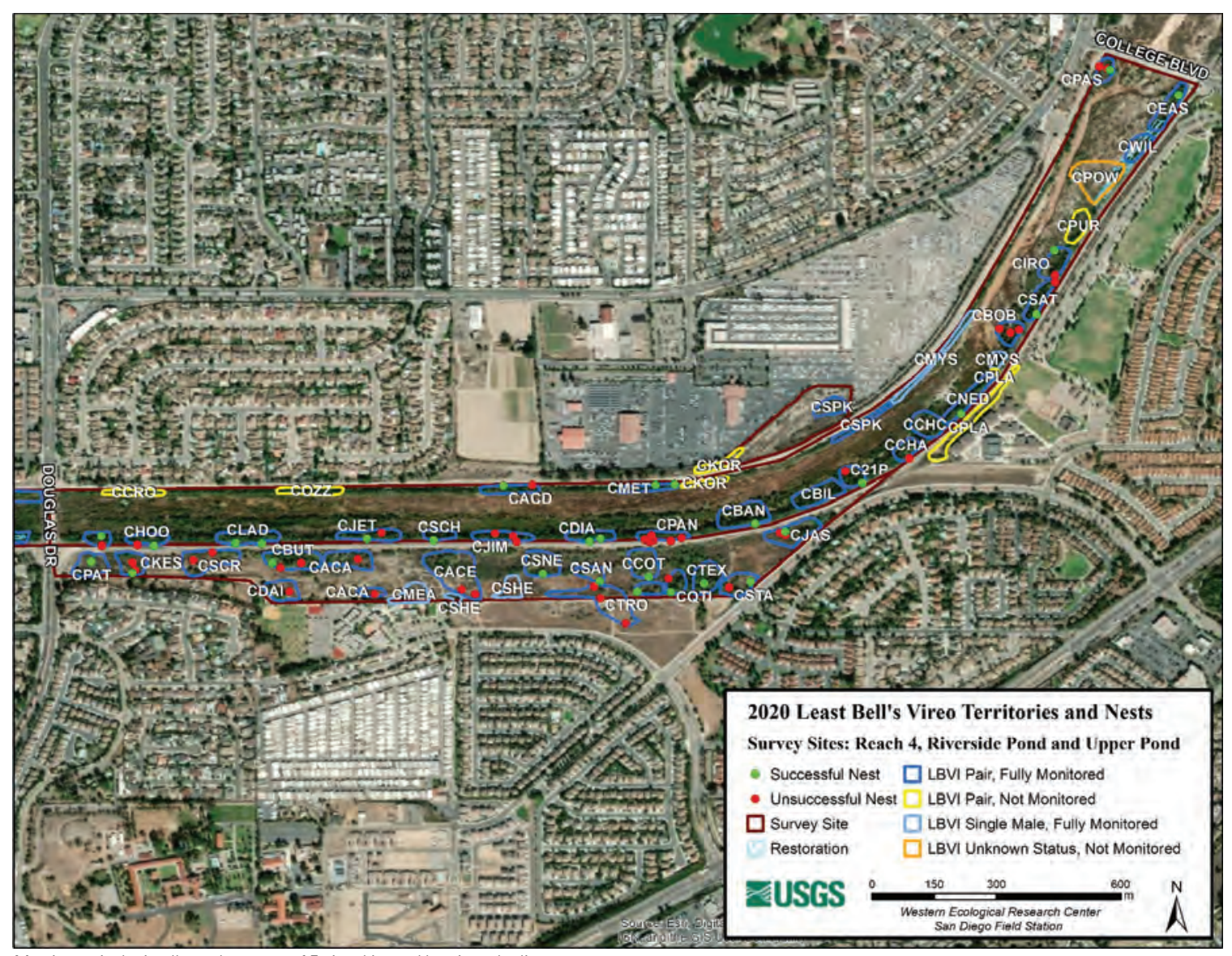

Map image is the intellectual property of Esri and is used herein under license.

Copyright $(\odot) 2020$ Esri and its licensors. All rights reserved.

Figure 2.4. Locations of Least Bell's Vireo territories and nests in the Reach 4, Riverside Pond, and Upper Pond survey sites at the San Luis Rey Flood Risk Management Project Area, California, in 2020. 


\section{Appendix 3. Status and Nesting Activities of Least Bell's Vireos at the San Luis Rey Flood Risk Management Project Area, California, in 2020}

This is an appendix of all monitored vireo nests with the nest location, nest fate, number of young fledged, and any relevant comments.

Table 3.1. Status and nesting activities of Least Bell's Vireos at the San Luis Rey Flood Risk Management Project Area, California, in 2020.

[Abbreviations: -, not applicable Nest Fate: FAL, nest built by unpaired male; INC, nest never completed; OTH, reason for nest failure known, such as substrate failure; PRE, nest failure caused by predation event; SUC, fledged at least one Least Bell's Vireo young; UNK, reason for nest failure/abandonment unknown]

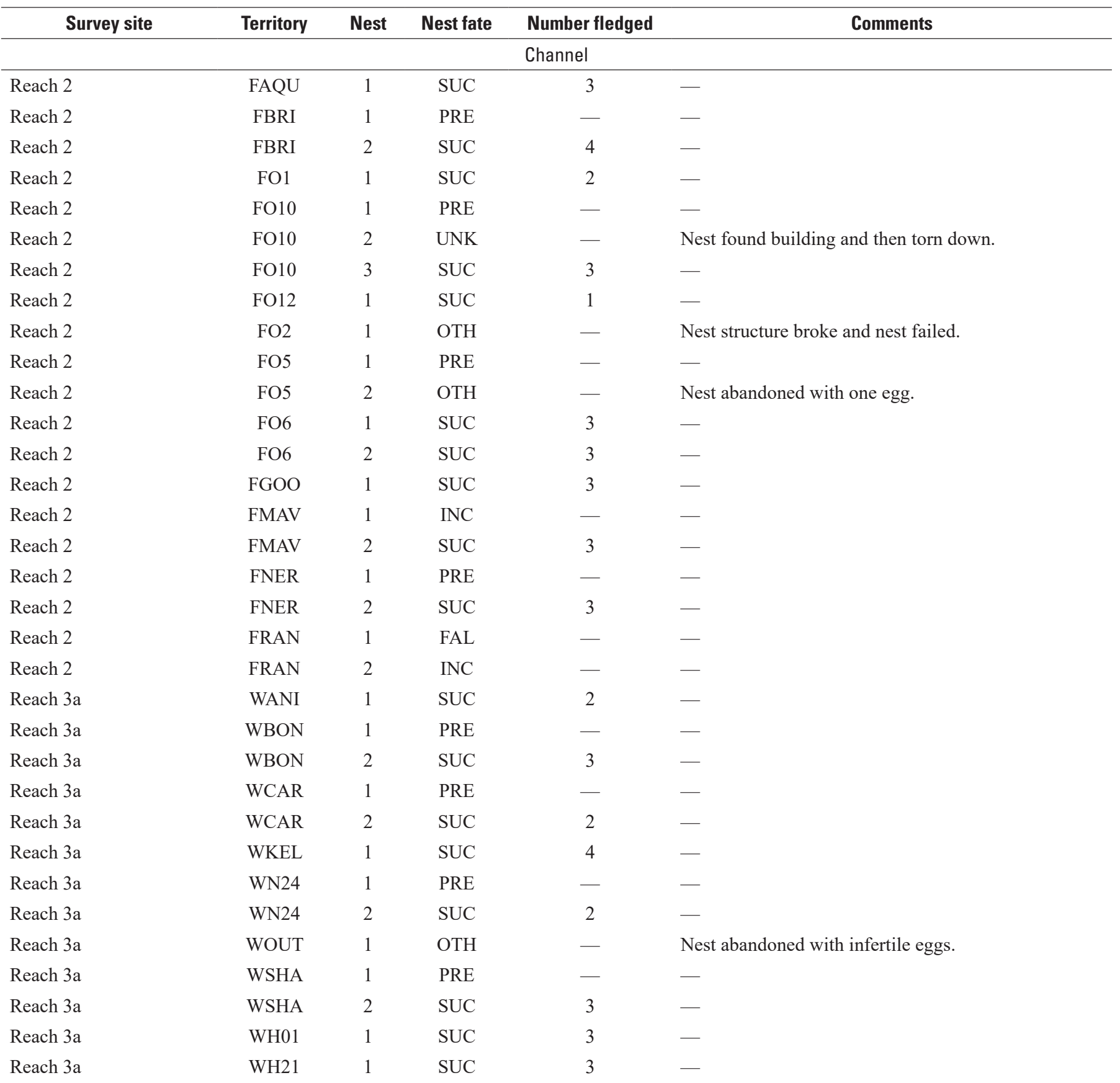


Table 3.1. Status and nesting activities of Least Bell's Vireos at the San Luis Rey Flood Risk Management Project Area, California, in 2020.-Continued

[Abbreviations: -, not applicable Nest Fate: FAL, nest built by unpaired male; INC, nest never completed; OTH, reason for nest failure known, such as substrate failure; PRE, nest failure caused by predation event; SUC, fledged at least one Least Bell's Vireo young; UNK, reason for nest failure/abandonment unknown]

\begin{tabular}{|c|c|c|c|c|c|}
\hline Survey site & Territory & Nest & Nest fate & Number fledged & Comments \\
\hline \multicolumn{6}{|c|}{ Channel-Continued } \\
\hline Reach 3a & WH24 & 1 & INC & - & - \\
\hline Reach $3 b$ & DBOW & 1 & SUC & 3 & - \\
\hline Reach $3 b$ & DBRU & 1 & SUC & 2 & - \\
\hline Reach $3 b$ & DDOL & 1 & OTH & - & Nest was washed away in flood. \\
\hline Reach $3 b$ & DDOL & 2 & SUC & 3 & - \\
\hline Reach $3 b$ & DDOL & 3 & SUC & 3 & - \\
\hline Reach $3 b$ & DDOU & 1 & FAL & - & - \\
\hline Reach $3 b$ & DDOU & 2 & FAL & - & - \\
\hline Reach $3 b$ & WJEW & 1 & OTH & - & Nest abandoned with infertile eggs. \\
\hline Reach $3 b$ & WJEW & 2 & PRE & - & - \\
\hline Reach $3 b$ & WJEW & 3 & PRE & - & - \\
\hline Reach $3 b$ & DMAC & 1 & PRE & - & - \\
\hline Reach $3 b$ & DMAD & 1 & SUC & 3 & - \\
\hline Reach $3 b$ & DMES & 1 & FAL & - & - \\
\hline Reach $3 b$ & DNIC & 1 & SUC & 2 & - \\
\hline Reach $3 b$ & DSAN & 1 & SUC & 3 & - \\
\hline Reach $3 b$ & DWIL & 3 & PRE & - & - \\
\hline Reach $3 b$ & DWIL & 4 & SUC & 3 & - \\
\hline Reach 4 & CACD & 1 & SUC & 3 & - \\
\hline Reach 4 & CACD & 2 & INC & - & - \\
\hline Reach 4 & CBAN & 1 & SUC & 3 & - \\
\hline Reach 4 & CBOB & 1 & PRE & - & - \\
\hline Reach 4 & $\mathrm{CBOB}$ & 2 & PRE & - & - \\
\hline Reach 4 & $\mathrm{CBOB}$ & 3 & PAR & - & - \\
\hline Reach 4 & $\mathrm{CCHA}$ & 1 & INC & - & - \\
\hline Reach 4 & CDIA & 1 & SUC & 4 & - \\
\hline Reach 4 & CDIA & 2 & SUC & 1 & - \\
\hline Reach 4 & CEAS & 1 & SUC & 4 & - \\
\hline Reach 4 & $\mathrm{CHOO}$ & 1 & PRE & - & - \\
\hline
\end{tabular}


Table 3.1. Status and nesting activities of Least Bell's Vireos at the San Luis Rey Flood Risk Management Project Area, California, in 2020.-Continued

[Abbreviations: - , not applicable Nest Fate: FAL, nest built by unpaired male; INC, nest never completed; OTH, reason for nest failure known, such as substrate failure; PRE, nest failure caused by predation event; SUC, fledged at least one Least Bell's Vireo young; UNK, reason for nest failure/abandonment unknown]

\begin{tabular}{|c|c|c|c|c|c|}
\hline Survey site & Territory & Nest & Nest fate & Number fledged & Comments \\
\hline \multicolumn{6}{|c|}{ Channel-Continued } \\
\hline Reach 4 & $\mathrm{CHOO}$ & 2 & SUC & 3 & - \\
\hline Reach 4 & CIRO & 2 & SUC & 3 & - \\
\hline Reach 4 & CJET & 1 & PRE & - & - \\
\hline Reach 4 & CJIM & 1 & PRE & - & - \\
\hline Reach 4 & CJIM & 2 & OTH & - & Argentinian ant predation. \\
\hline Reach 4 & CJIM & 3 & INC & - & - \\
\hline Reach 4 & CLAD & 1 & SUC & 3 & - \\
\hline Reach 4 & CLAD & 2 & SUC & 1 & - \\
\hline Reach 4 & CPAN & 1 & UNK & - & Nest abandoned but eggs were never confirmed. \\
\hline Reach 4 & CPAN & 2 & UNK & - & Nest abandoned but eggs were never confirmed. \\
\hline Reach 4 & CPAN & 3 & UNK & - & Nest abandoned but eggs were never confirmed. \\
\hline Reach 4 & CPAN & 4 & UNK & - & Nest abandoned but eggs were never confirmed. \\
\hline Reach 4 & CPAN & 5 & UNK & - & Nest abandoned but eggs were never confirmed. \\
\hline Reach 4 & CPAN & 6 & UNK & - & Nest abandoned but eggs were never confirmed. \\
\hline Reach 4 & CPAS & 1 & PRE & - & - \\
\hline Reach 4 & CPAS & 2 & PAR & - & - \\
\hline Reach 4 & CG21P & 1 & PRE & - & - \\
\hline Reach 4 & CG21P & 2 & SUC & 3 & - \\
\hline \multicolumn{6}{|c|}{ Off-channel } \\
\hline Pilgrim Pond & D157 & 1 & PRE & - & - \\
\hline Pilgrim Pond & D157 & 2 & SUC & 3 & - \\
\hline Upper Pond & CACA & 1 & PRE & - & - \\
\hline Upper Pond & CACA & 2 & INC & - & - \\
\hline Upper Pond & CACE & 1 & PRE & - & - \\
\hline Upper Pond & CACE & 2 & PRE & - & - \\
\hline Upper Pond & CBUT & 1 & PRE & - & - \\
\hline Upper Pond & CBUT & 2 & INC & - & - \\
\hline Upper Pond & CBUT & 3 & SUC & 3 & - \\
\hline Upper Pond & CCOT & 1 & SUC & 4 & - \\
\hline
\end{tabular}


Table 3.1. Status and nesting activities of Least Bell's Vireos at the San Luis Rey Flood Risk Management Project Area, California, in 2020.-Continued

[Abbreviations: - , not applicable Nest Fate: FAL, nest built by unpaired male; INC, nest never completed; OTH, reason for nest failure known, such as substrate failure; PRE, nest failure caused by predation event; SUC, fledged at least one Least Bell's Vireo young; UNK, reason for nest failure/abandonment unknown]

\begin{tabular}{|c|c|c|c|c|c|}
\hline Survey site & Territory & Nest & Nest fate & Number fledged & Comments \\
\hline \multicolumn{6}{|c|}{ Off-channel-Continued } \\
\hline Upper Pond & CDAI & 1 & PRE & - & - \\
\hline Upper Pond & CJAS & 2 & INC & - & - \\
\hline Upper Pond & CJAS & 3 & SUC & 3 & - \\
\hline Upper Pond & CKES & 2 & INC & - & - \\
\hline Upper Pond & CKES & 3 & SUC & 4 & - \\
\hline Upper Pond & CPAT & 1 & SUC & 2 & - \\
\hline Upper Pond & CQTI & 1 & PRE & - & - \\
\hline Upper Pond & CQTI & 2 & SUC & 3 & - \\
\hline Upper Pond & CSCR & 2 & PRE & - & - \\
\hline Upper Pond & CSNE & 1 & SUC & 4 & - \\
\hline Upper Pond & CSTA & 1 & PRE & - & - \\
\hline Upper Pond & CSTA & 2 & SUC & 4 & - \\
\hline Upper Pond & CTEX & 1 & SUC & 3 & - \\
\hline Upper Pond & CTRO & 1 & FAL & - & - \\
\hline Upper Pond & CTRO & 2 & PRE & - & - \\
\hline Upper Pond & CTRO & 3 & PRE & - & - \\
\hline Whelan Mitigation & WDOB & 2 & PRE & - & - \\
\hline Whelan Mitigation & WDOB & 3 & SUC & 2 & - \\
\hline Whelan Mitigation & WDOC & 1 & PRE & - & - \\
\hline Whelan Mitigation & WFID & 1 & SUC & 3 & - \\
\hline Whelan Mitigation & WMRG & 1 & SUC & 4 & - \\
\hline Whelan Mitigation & WMIL & 1 & PRE & - & - \\
\hline Whelan Mitigation & WMIL & 2 & INC & - & - \\
\hline Whelan Mitigation & WMIL & 3 & PRE & - & - \\
\hline Whelan Mitigation & WMIL & 4 & SUC & 1 & - \\
\hline Whelan Mitigation & WH27 & 1 & PRE & - & - \\
\hline Whelan Mitigation & WH27 & 2 & PRE & - & - \\
\hline
\end{tabular}


Table 3.1. Status and nesting activities of Least Bell's Vireos at the San Luis Rey Flood Risk Management Project Area, California, in 2020.-Continued

[Abbreviations: - , not applicable Nest Fate: FAL, nest built by unpaired male; INC, nest never completed; OTH, reason for nest failure known, such as substrate failure; PRE, nest failure caused by predation event; SUC, fledged at least one Least Bell's Vireo young; UNK, reason for nest failure/abandonment unknown]

\begin{tabular}{cccccc}
\hline \multicolumn{1}{c}{ Survey site } & Territory & Nest & Nest fate & Number fledged & Comments \\
\hline Whelan Restoration & & & & Restoration & \\
Whelan Restoration & WEMI & 1 & SUC & 4 & - \\
Whelan Restoration & WGEE & 2 & SUC & 3 & - \\
Whelan Restoration & WGIL & 1 & INC & - & - \\
Whelan Restoration & WGRI & 1 & SUC & 4 & - \\
Whelan Restoration & WGRI & 2 & PRE & - & - \\
Whelan Restoration & WSTA & 1 & PRE & - & - \\
Whelan Restoration & WSTA & 2 & OTH & - & Nest abandoned with one egg. \\
\hline
\end{tabular}




\section{Appendix 4. Banded Adult Least Bell's Vireos at the San Luis Rey Flood Risk Management Project Area, California, in 2020}

This is an appendix of all banded adult vireos identified in the Project Area in 2020. The band combinations are listed along with the age and sex of the bird.

Table 4.1. Banded adult Least Bell's Vireos at the San Luis Rey Flood Risk Management Project Area, California, in 2020.

[Band combo orientation on leg (left leg: right leg). Abbreviations: Band colors: BKBK, plastic black; BKLP, plastic black-light pink split; BKYE, plastic black-yellow split; BPST, plastic black-pink striped; BWST, plastic blue-white striped; BYST, plastic black-yellow striped; DBDP, plastic dark blue-dark pink split; DBWH, plastic dark blue-white split; DPDB, plastic dark pink-dark blue split; DPDP, plastic dark pink; DPWH, plastic dark pink-white split; gogo, metal gold; LPBK, plastic light pink-black split; Mdb, dark blue numbered federal band; Msi, silver numbered federal band; pupu, metal purple; PUPU, plastic purple; PUWH, plastic purple-white split; PUYE, plastic purple-yellow split; WHDB, plastic white-dark blue split; WHDP, plastic white-dark pink split; WHPU, plastic white-purple split; WHWH, plastic white; YEBK, plastic yellow-black split; YEPU, plastic yellow-purple split; YEYE, plastic yellow. Age: Exact age determined from uniquely numbered metal band observed during recapture; estimated age applies to an unbanded bird captured as an after-hatch-year. Sex: M, male, $\mathrm{F}$, female. yr, year; $\geq$, greater than or equal to]

\begin{tabular}{|c|c|c|c|c|}
\hline Territory & $\begin{array}{l}\text { Band combination } \\
\text { (left leg: right leg) }\end{array}$ & Age & Sex & Comments \\
\hline BFAT & WHDP: PUYE Mdb & $3 \mathrm{yrs}$ & M & $\begin{array}{l}\text { Banded as a nestling in BKEN territory in 2017. Color banded in BFAT } \\
\text { territory in } 2020 .\end{array}$ \\
\hline BFIL & BPST: Mdb & $1 \mathrm{yr}$ & $\mathrm{F}$ & $\begin{array}{l}\text { Banded as a nestling in WH25 territory in 2019. Color banded in BFIL } \\
\text { territory in } 2020 .\end{array}$ \\
\hline BHAZ & YEBK: ? & $\geq 1 \mathrm{yr}$ & $\mathrm{F}$ & Banded as unknown age at an unknown location before 2020 . \\
\hline BLEM & $: \mathrm{Mdb}$ & $\geq 1 \mathrm{yr}$ & $\mathrm{F}$ & Banded as a nestling at the San Luis Rey River before 2020. \\
\hline BPAM & WHDB Mdb: WHWH & $\geq 6$ yrs & M & Banded as AHY in BPOI territory in 2015. \\
\hline BPAT & DPDB Mdb: DPDP & $\geq 4$ yrs & $\mathrm{F}$ & Banded as AHY in BPAT territory in 2017. \\
\hline BPAT & PUPU Mdb: & $\geq 4$ yrs & M & Banded as AHY in BPAT territory in 2017. \\
\hline BSAL & WHWH Mdb: BKBK & $\geq 8$ yrs & M & Banded as AHY in BHAN territory in 2013. \\
\hline BSHC & LPBK Mdb: WHDB & $\geq 7 \mathrm{yrs}$ & M & Banded as AHY in BBOA territory in 2014. \\
\hline BT01 & BPST: BYST Mdb & 3 yrs & M & $\begin{array}{l}\text { Banded as a nestling in WH30 territory in 2017. Color banded in BTHR } \\
\text { territory in } 2019 .\end{array}$ \\
\hline BTHR & $: \mathrm{Mdb}$ & $\geq 1 \mathrm{yr}$ & $\mathrm{F}$ & Banded as a nestling at the San Luis Rey River before 2020. \\
\hline BTOK & LPBK: BKLP Mdb & $\geq 6$ yrs & M & Banded as AHY in BKEN territory in 2015. \\
\hline $\mathrm{C} 21 \mathrm{P}$ & pupu: PUPU Mdb & $1 \mathrm{yr}$ & M & $\begin{array}{l}\text { Banded as a nestling in DBOW territory in 2019. Color banded in C21P } \\
\text { territory in } 2020 .\end{array}$ \\
\hline $\mathrm{CCHA}$ & PUPU Mdb: DBDP & $\geq 8$ yrs & M & Banded as AHY in CCHA territory in 2013. \\
\hline $\mathrm{CCHC}$ & $: \mathrm{Mdb}$ & $\geq 1 \mathrm{yr}$ & M & Banded as a nestling at the San Luis Rey River before 2020. \\
\hline
\end{tabular}


Table 4.1. Banded adult Least Bell's Vireos at the San Luis Rey Flood Risk Management Project Area, California, in 2020.-Continued

[Band combo orientation on leg (left leg: right leg). Abbreviations: Band colors: BKBK, plastic black; BKLP, plastic black-light pink split; BKYE, plastic black-yellow split; BPST, plastic black-pink striped; BWST, plastic blue-white striped; BYST, plastic black-yellow striped; DBDP, plastic dark blue-dark pink split; DBWH, plastic dark blue-white split; DPDB, plastic dark pink-dark blue split; DPDP, plastic dark pink; DPWH, plastic dark pink-white split; gogo, metal gold; LPBK, plastic light pink-black split; Mdb, dark blue numbered federal band; Msi, silver numbered federal band; pupu, metal purple; PUPU, plastic purple; PUWH, plastic purple-white split; PUYE, plastic purple-yellow split; WHDB, plastic white-dark blue split; WHDP, plastic white-dark pink split; WHPU, plastic white-purple split; WHWH, plastic white; YEBK, plastic yellow-black split; YEPU, plastic yellow-purple split; YEYE, plastic yellow. Age: Exact age determined from uniquely numbered metal band observed during recapture; estimated age applies to an unbanded bird captured as an after-hatch-year. Sex: M, male, F, female. yr, year; $\geq$, greater than or equal to]

\begin{tabular}{|c|c|c|c|c|}
\hline Territory & $\begin{array}{l}\text { Band combination } \\
\text { (left leg: right leg) }\end{array}$ & Age & Sex & Comments \\
\hline CCOT & BKBK Mdb: BPST & $2 \mathrm{yrs}$ & $\mathrm{F}$ & $\begin{array}{l}\text { Banded as a nestling in WEEB territory in 2018. Color banded in } \\
\text { CCOT territory in } 2020 .\end{array}$ \\
\hline CCOT & YEPU: BKBK Mdb & $5 \mathrm{yrs}$ & M & $\begin{array}{l}\text { Banded as a nestling in CSCH territory in 2015. Color banded in CCOT } \\
\text { territory in } 2016 .\end{array}$ \\
\hline CCRO & YEPU: DBDP Mdb & $1 \mathrm{yr}$ & M & $\begin{array}{l}\text { Banded as a nestling in WGRI territory in } 2019 \text {. Color banded in } \\
\text { CCRO territory in } 2020 .\end{array}$ \\
\hline CDAI & $: \mathrm{Mdb}$ & $\geq 1 \mathrm{yr}$ & $\mathrm{F}$ & Banded as a nestling at the San Luis Rey River before 2020 . \\
\hline CDIA & PUWH: PUYE Mdb & $1 \mathrm{yr}$ & M & $\begin{array}{l}\text { Banded as a nestling in DGWE territory in 2019. Color banded in } \\
\text { CDIA territory in } 2020 .\end{array}$ \\
\hline CEAS & BPST Mdb: YEBK & $2 \mathrm{yrs}$ & M & $\begin{array}{l}\text { Banded as a nestling in CFLO territory in 2018. Color banded in } \\
\text { MSL161 territory in } 2019 .\end{array}$ \\
\hline CJET & : PUPU Mdb & 4 yrs & M & $\begin{array}{l}\text { Banded as a nestling in CNED territory in 2016. Color banded in CJET } \\
\text { territory in } 2017 .\end{array}$ \\
\hline CJIM & BPST: DPWH Mdb & $\geq 2 \mathrm{yrs}$ & M & Banded as AHY in CJIM territory in 2019. \\
\hline CKES & PUYE: WHDB Mdb & $\geq 2 \mathrm{yrs}$ & M & Banded as AHY in CSCR territory in 2019. \\
\hline CKOR & $: \mathrm{Mdb}$ & $\geq 1 \mathrm{yr}$ & M & Banded as a nestling at the San Luis Rey River before 2020 . \\
\hline CLAD & BYST: BKBK Mdb & 9 yrs & $\mathrm{F}$ & $\begin{array}{l}\text { Banded as a nestling in WDID territory in 2011. Color banded in } \\
\text { CNED territory in } 2016 \text {. }\end{array}$ \\
\hline CLAD & DBWH: PUWH Mdb & $\geq 2 \mathrm{yrs}$ & M & Banded as AHY in CLAD territory in 2019. \\
\hline CMET & BPST Mdb: pupu & $\geq 3 \mathrm{yrs}$ & M & Banded as AHY in CMET territory in 2018. \\
\hline CPAS & WHDP Mdb: YEPU & $\geq 1 \mathrm{yr}$ & M & Banded as AHY in CPAS territory in 2020. \\
\hline CPAT & PUWH Mdb: YEBK & $\geq 2 \mathrm{yrs}$ & M & Banded as AHY in CFOR territory in 2019. \\
\hline CPLA & $: \mathrm{Mdb}$ & $\geq 1 \mathrm{yr}$ & $\mathrm{F}$ & Banded as a nestling at the San Luis Rey River before 2020 . \\
\hline CPUR & YEBK: PUPU Mdb & $\geq 2$ yrs & M & Banded as AHY in CPOW territory in 2019. \\
\hline CQTI & WHDB: BKLP Mdb & $7 \mathrm{yrs}$ & M & $\begin{array}{l}\text { Banded as a nestling in CEAS territory in 2013. Color banded in CDIA } \\
\text { territory in 2014. }\end{array}$ \\
\hline CRED & DBWH pupu: Mdb & $1 \mathrm{yr}$ & M & $\begin{array}{l}\text { Banded as a nestling in CJET territory in 2019. Color banded in CRED } \\
\text { territory in } 2020 .\end{array}$ \\
\hline CSAN & pupu: DPWH Mdb & $1 \mathrm{yr}$ & $\mathrm{F}$ & $\begin{array}{l}\text { Banded as a nestling in WOUT territory in 2019. Color banded in } \\
\text { CSAN territory in } 2020 .\end{array}$ \\
\hline CSAN & BPST: WHDB Mdb & $\geq 2 \mathrm{yrs}$ & M & Banded as AHY in CDIS territory in 2019. \\
\hline
\end{tabular}


Table 4.1. Banded adult Least Bell's Vireos at the San Luis Rey Flood Risk Management Project Area, California, in 2020.—Continued

[Band combo orientation on leg (left leg: right leg). Abbreviations: Band colors: BKBK, plastic black; BKLP, plastic black-light pink split; BKYE, plastic black-yellow split; BPST, plastic black-pink striped; BWST, plastic blue-white striped; BYST, plastic black-yellow striped; DBDP, plastic dark blue-dark pink split; DBWH, plastic dark blue-white split; DPDB, plastic dark pink-dark blue split; DPDP, plastic dark pink; DPWH, plastic dark pink-white split; gogo, metal gold; LPBK, plastic light pink-black split; Mdb, dark blue numbered federal band; Msi, silver numbered federal band; pupu, metal purple; PUPU, plastic purple; PUWH, plastic purple-white split; PUYE, plastic purple-yellow split; WHDB, plastic white-dark blue split; WHDP, plastic white-dark pink split; WHPU, plastic white-purple split; WHWH, plastic white; YEBK, plastic yellow-black split; YEPU, plastic yellow-purple split; YEYE, plastic yellow. Age: Exact age determined from uniquely numbered metal band observed during recapture; estimated age applies to an unbanded bird captured as an after-hatch-year. Sex: M, male, $F$, female. yr, year; $\geq$, greater than or equal to]

\begin{tabular}{|c|c|c|c|c|}
\hline Territory & $\begin{array}{l}\text { Band combination } \\
\text { (left leg: right leg) }\end{array}$ & Age & Sex & Comments \\
\hline CSAT & WHDP Mdb: YEBK & 4 yrs & $\mathrm{F}$ & $\begin{array}{l}\text { Banded as a nestling in WALY territory in 2016. Color banded in CPUR } \\
\text { territory in } 2019 .\end{array}$ \\
\hline CSAT & YEPU Mdb: DPDP & $\geq 3 \mathrm{yrs}$ & M & Banded as AHY in CIRO territory in 2018. \\
\hline $\mathrm{CSCH}$ & BYST Mdb: WHDP & 4 yrs & $\mathrm{F}$ & $\begin{array}{l}\text { Banded as a nestling in DBOW territory in 2016. Color banded in } \\
\text { CACE territory in } 2019 .\end{array}$ \\
\hline CSNE & BPST Mdb: YEPU & $\geq 1 \mathrm{yr}$ & $\mathrm{M}$ & Banded as AHY in CSNE territory in 2020. \\
\hline CSPA & WHDB Mdb: YEPU & $\geq 1 \mathrm{yr}$ & M & Banded as AHY in CSPA territory in 2020. \\
\hline CSTA & DPDB Mdb: PUWH & $\geq 3 \mathrm{yrs}$ & M & Banded as AHY in CSTA territory in 2018. \\
\hline CTRO & DPDP: PUYE Mdb & $1 \mathrm{yr}$ & M & $\begin{array}{l}\text { Banded as a nestling in WOUT territory in 2019. Color banded in } \\
\text { CTRO territory in } 2020 .\end{array}$ \\
\hline DBRU & DBWH: BKYE Mdb & $1 \mathrm{yr}$ & $\mathrm{F}$ & $\begin{array}{l}\text { Banded as a nestling in FO2 territory in 2019. Color banded in DBRU } \\
\text { territory in } 2020 .\end{array}$ \\
\hline DBRU & BPST Mdb: DBDP & $\geq 1 \mathrm{yr}$ & M & Banded as AHY in DBRU territory in 2020. \\
\hline DCHE & DBWH Mdb: PUWH & $\geq 1 \mathrm{yr}$ & $\mathrm{M}$ & Banded as AHY in DCHE territory in 2020. \\
\hline DDOL & BPST Mdb: PUWH & $2 \mathrm{yrs}$ & $\mathrm{F}$ & $\begin{array}{l}\text { Banded as a nestling in DWIL territory in 2018. Color banded in CJAS } \\
\text { territory in } 2019 .\end{array}$ \\
\hline DDOL & WHDP Mdb: PUWH & $\geq 3$ yrs & M & Banded as AHY in DWHI territory in 2018. \\
\hline DDOU & DPDP: BKYE Mdb & 3 yrs & $\mathrm{F}$ & $\begin{array}{l}\text { Banded as a nestling in WGIL territory in 2017. Color banded in CDIA } \\
\text { territory in } 2018 \text {. }\end{array}$ \\
\hline DMES & WHDB Mdb: DBDP & $2 \mathrm{yrs}$ & M & $\begin{array}{l}\text { Banded as a nestling in COZZ territory in } 2018 \text {. Color banded in } \\
\text { WH200 territory in } 2019 \text {. }\end{array}$ \\
\hline DNIC & WHPU: DPDB Mdb & $1 \mathrm{yr}$ & M & $\begin{array}{l}\text { Banded as a nestling in WGEE territory in 2019. Color banded in DNIC } \\
\text { territory in } 2020 \text {. }\end{array}$ \\
\hline DSAN & YEPU: BPST Mdb & $\geq 1 \mathrm{yr}$ & M & Banded as AHY in DSAN territory in 2020. \\
\hline DSIM & DPWH pupu: Mdb & $\geq 1 \mathrm{yr}$ & $\mathrm{M}$ & Banded as AHY in DSIM territory in 2020. \\
\hline DTOS & WHPU: PUPU Mdb & $1 \mathrm{yr}$ & M & $\begin{array}{l}\text { Banded as a nestling in FO11 territory in 2019. Color banded in DTOS } \\
\text { territory in } 2020 .\end{array}$ \\
\hline DWIL & YEPU Mdb: WHDB & $4 \mathrm{yrs}$ & M & $\begin{array}{l}\text { Banded as a nestling in BSAV territory in 2016. Color banded in DWIL } \\
\text { territory in } 2017 .\end{array}$ \\
\hline FAQU & WHPU Mdb: BKYE & $\geq 1 \mathrm{yr}$ & $\mathrm{M}$ & Banded as AHY in FAQU territory in 2020. \\
\hline
\end{tabular}


Table 4.1. Banded adult Least Bell's Vireos at the San Luis Rey Flood Risk Management Project Area, California, in 2020.—Continued

[Band combo orientation on leg (left leg: right leg). Abbreviations: Band colors: BKBK, plastic black; BKLP, plastic black-light pink split; BKYE, plastic black-yellow split; BPST, plastic black-pink striped; BWST, plastic blue-white striped; BYST, plastic black-yellow striped; DBDP, plastic dark blue-dark pink split; DBWH, plastic dark blue-white split; DPDB, plastic dark pink-dark blue split; DPDP, plastic dark pink; DPWH, plastic dark pink-white split; gogo, metal gold; LPBK, plastic light pink-black split; Mdb, dark blue numbered federal band; Msi, silver numbered federal band; pupu, metal purple; PUPU, plastic purple; PUWH, plastic purple-white split; PUYE, plastic purple-yellow split; WHDB, plastic white-dark blue split; WHDP, plastic white-dark pink split; WHPU, plastic white-purple split; WHWH, plastic white; YEBK, plastic yellow-black split; YEPU, plastic yellow-purple split; YEYE, plastic yellow. Age: Exact age determined from uniquely numbered metal band observed during recapture; estimated age applies to an unbanded bird captured as an after-hatch-year. Sex: M, male, F, female. yr, year; $\geq$, greater than or equal to]

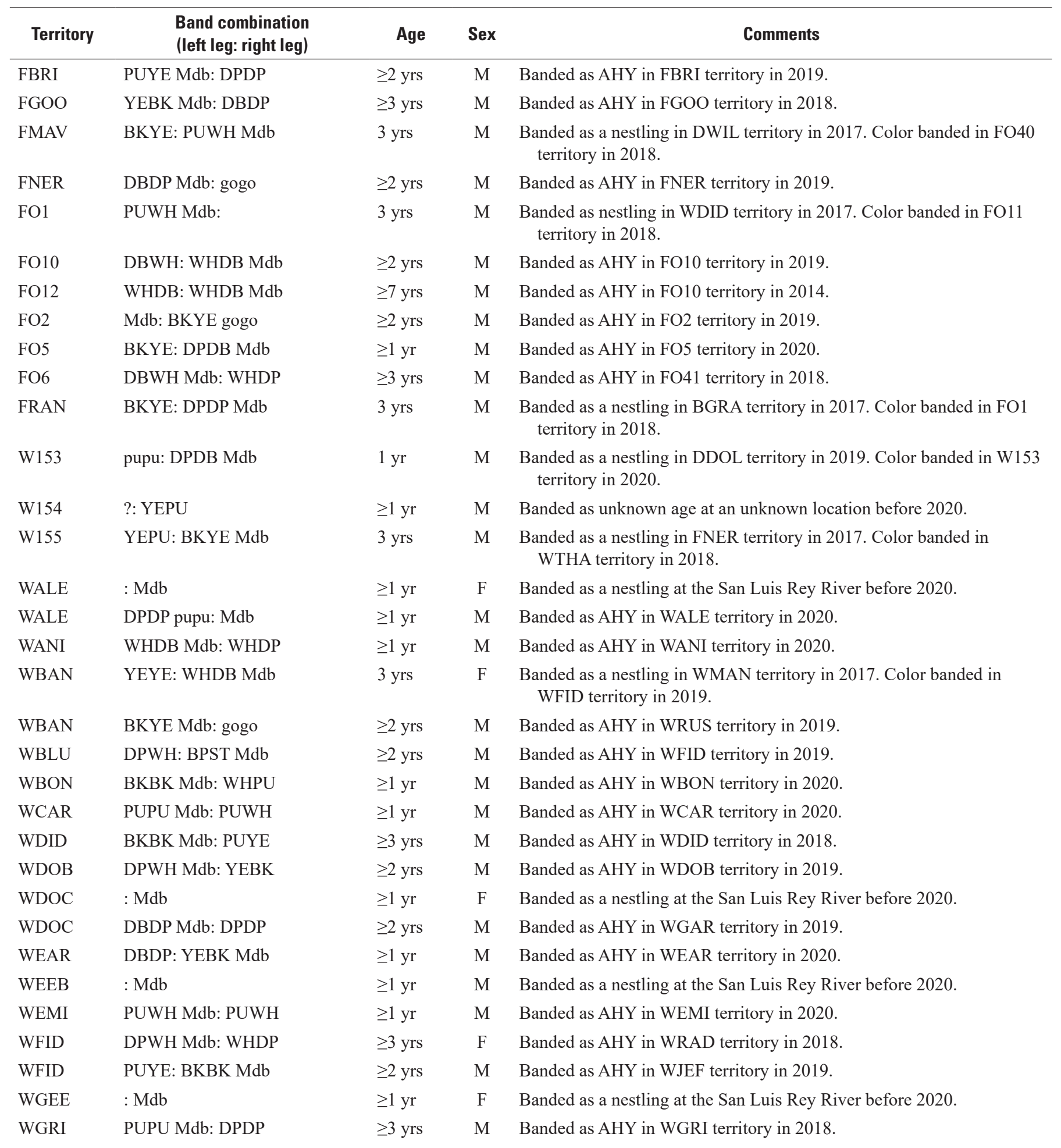


Table 4.1. Banded adult Least Bell's Vireos at the San Luis Rey Flood Risk Management Project Area, California, in 2020.—Continued

[Band combo orientation on leg (left leg: right leg). Abbreviations: Band colors: BKBK, plastic black; BKLP, plastic black-light pink split; BKYE, plastic black-yellow split; BPST, plastic black-pink striped; BWST, plastic blue-white striped; BYST, plastic black-yellow striped; DBDP, plastic dark blue-dark pink split; DBWH, plastic dark blue-white split; DPDB, plastic dark pink-dark blue split; DPDP, plastic dark pink; DPWH, plastic dark pink-white split; gogo, metal gold; LPBK, plastic light pink-black split; Mdb, dark blue numbered federal band; Msi, silver numbered federal band; pupu, metal purple; PUPU, plastic purple; PUWH, plastic purple-white split; PUYE, plastic purple-yellow split; WHDB, plastic white-dark blue split; WHDP, plastic white-dark pink split; WHPU, plastic white-purple split; WHWH, plastic white; YEBK, plastic yellow-black split; YEPU, plastic yellow-purple split; YEYE, plastic yellow. Age: Exact age determined from uniquely numbered metal band observed during recapture; estimated age applies to an unbanded bird captured as an after-hatch-year. Sex: M, male, $\mathrm{F}$, female. yr, year; $\geq$, greater than or equal to]

\begin{tabular}{|c|c|c|c|c|}
\hline Territory & $\begin{array}{l}\text { Band combination } \\
\text { (left leg: right leg) }\end{array}$ & Age & Sex & Comments \\
\hline WH01 & DBWH Mdb: BKYE & $\geq 1 \mathrm{yr}$ & M & Banded as AHY in WH01 territory in 2020. \\
\hline WH21 & DPDB Mdb: WHPU & $2 \mathrm{yrs}$ & M & $\begin{array}{l}\text { Banded as a nestling in DBEL territory in } 2018 \text {. Color banded in WH25 } \\
\text { territory in } 2019 .\end{array}$ \\
\hline WH28 & ?: BWST Mdb & $\geq 1 \mathrm{yr}$ & M & Banded as unknown age at the San Luis Rey River before 2020. \\
\hline WH29 & DBDP: WHWH Mdb & $1 \mathrm{yr}$ & M & $\begin{array}{l}\text { Banded as a nestling in CCHA territory in } 2019 \text {. Color banded in } \\
\text { WH29 territory in } 2020 .\end{array}$ \\
\hline WH30 & YEYE: BYST Mdb & 3 yrs & M & $\begin{array}{l}\text { Banded as a nestling in BHAN territory in 2017. Color banded in } \\
\text { WH30 territory in } 2018 .\end{array}$ \\
\hline WHRH & WHDB Mdb: BKYE & $\geq 1 \mathrm{yr}$ & M & Banded as AHY in WHRH territory in 2020. \\
\hline WJEF & $: \mathrm{Mdb}$ & $\geq 1 \mathrm{yr}$ & M & Banded as a nestling at the San Luis Rey River before 2020 . \\
\hline WJEW & pupu: YEPU Mdb & $1 \mathrm{yr}$ & M & $\begin{array}{l}\text { Banded as a nestling in FNER territory in 2019. Color banded in } \\
\text { WJEW territory in } 2020 .\end{array}$ \\
\hline WKEL & BPST Mdb: PUPU & $\geq 1 \mathrm{yr}$ & $\mathrm{F}$ & Banded as AHY in WKEL territory in 2020. \\
\hline WMAN & : PUYE & $\geq 3 \mathrm{yrs}$ & M & Banded as AHY in WMAN territory in 2018. \\
\hline WMIL & YEPU Mdb: PUWH & $\geq 1 \mathrm{yr}$ & M & Banded as AHY in WMIL territory in 2020. \\
\hline WMON & BKYE Mdb: WHDP & $\geq 1 \mathrm{yr}$ & $\mathrm{F}$ & Banded as AHY in WMON territory in 2020. \\
\hline WOUT & BKYE: WHDB Mdb & $\geq 1 \mathrm{yr}$ & M & Banded as AHY in WOUT territory in 2020. \\
\hline WSHA & pupu: BKBK Mdb & $\geq 1 \mathrm{yr}$ & M & Banded as AHY in WSHA territory in 2020. \\
\hline WSTA & PUPU: Mdb & $1 \mathrm{yr}$ & $\mathrm{F}$ & $\begin{array}{l}\text { Banded as a nestling in FO19 territory in 2019. Color banded in WSTA } \\
\text { territory in } 2020 \text {. }\end{array}$ \\
\hline WSTA & DPDP: YEBK Mdb & $\geq 2$ yrs & M & Banded as AHY in WGEE territory in 2019. \\
\hline
\end{tabular}




\section{Appendix 5. Between-year Movement of Emigrant Least Bell's Vireos from the San Luis Rey Flood Risk Management Project Area to Other Areas Outside of the Project Area in California, 2020}

The table in this appendix lists Least Bell's Vireos that emigrated from the Project Area to areas outside of the Project Area in 2020. The table includes the original territory, 2020 territory, dispersal distance, age, and sex of the bird.

Table 5.1. Between-year movement of emigrant Least Bell's Vireos from the San Luis Rey Flood Risk Management Project Area to other areas outside of the Project Area in California, 2020.

[Abbreviations: Location: MCBCP, Marine Corps Base Camp Pendleton; Band. Colors: BKBK, plastic black; BKYE, plastic black-yellow split; BPST, plastic black-pink striped; BWST, plastic blue-white striped; DBDP, plastic dark blue-dark pink split; DBWH, plastic dark blue-white split; DPDP, plastic dark pink; DPWH, plastic dark pink-white split; Mdb, dark blue numbered federal band; PUPU, plastic purple; PUWH, plastic purple-white split; WHDB, plastic white-dark blue split; WHPU, white-purple split; YEBK, plastic yellow-black split; YEYE, plastic yellow. Age: Exact age determined from uniquely numbered metal band observed during recapture; estimated age applies to an unbanded bird captured as an adult. Sex: M, male; F, female. km, kilometer; yr, year; $\geq$, greater than or equal to]

\begin{tabular}{|c|c|c|c|c|c|}
\hline Drainage/natal territory & 2020 Drainage/territory/location & $\begin{array}{c}\text { Dispersal } \\
\text { distance } \\
\text { (km) }\end{array}$ & $\begin{array}{l}\text { Band combination } \\
\text { (left leg: right leg) }\end{array}$ & $\begin{array}{c}\text { Age in } \\
2020\end{array}$ & Sex \\
\hline San Luis Rey River/BRAT & Santa Margarita River / JABBA / MCBCP & 7.51 & WHDB Mdb: WHDB & 4 yrs & $\mathrm{F}$ \\
\hline San Luis Rey River/FRAS & Pilgrim Creek / PS15 / MCBCP & 8.06 & BKBK: DBDP Mdb & $3 \mathrm{yrs}$ & $\mathrm{F}$ \\
\hline San Luis Rey River/CSNE & San Diego River / EC02 & 55.20 & Mdb: & $2 \mathrm{yrs}$ & M \\
\hline San Luis Rey River/WFIR & Pilgrim Creek / PS30 / MCBCP & 6.86 & WHPU Mdb: DPWH & $2 \mathrm{yrs}$ & M \\
\hline San Luis Rey River/WMON & Santa Margarita River / BN18 / MCBCP & 4.25 & DPDP Mdb: BPST & $2 \mathrm{yrs}$ & $\mathrm{F}$ \\
\hline San Luis Rey River/unknown & Middle San Luis Rey River / MSL187 & 1.13 & $: \mathrm{Mdb}$ & $\geq 1 \mathrm{yr}$ & M \\
\hline San Luis Rey River/unknown & Middle San Luis Rey River / MSL127 & 1.10 & $: \mathrm{Mdb}$ & $\geq 1 \mathrm{yr}$ & M \\
\hline San Luis Rey River/unknown & Middle San Luis Rey River / MSL161 & 0.38 & $: \mathrm{Mdb}$ & $\geq 1 \mathrm{yr}$ & M \\
\hline San Luis Rey River/unknown & Ysidora Basin / YB17 / MCBCP & 6.02 & $: \mathrm{Mdb}$ & $\geq 1 \mathrm{yr}$ & $\mathrm{F}$ \\
\hline San Luis Rey River/unknown & Middle San Luis Rey River / MSL122 & 1.66 & $: \mathrm{Mdb}$ & $\geq 1 \mathrm{yr}$ & $\mathrm{F}$ \\
\hline San Luis Rey River/unknown & Middle San Luis Rey River / MSL162 & 2.16 & $: \mathrm{Mdb}$ & $\geq 1 \mathrm{yr}$ & $\mathrm{F}$ \\
\hline San Luis Rey River/unknown & Pilgrim Creek / PS34 / MCBCP & 3.54 & $: \mathrm{Mdb}$ & $\geq 1 \mathrm{yr}$ & $\mathrm{F}$ \\
\hline San Luis Rey River/CFOR & Santa Margarita River / HE38 / MCBCP & 9.22 & DPWH: BKYE Mdb & $1 \mathrm{yr}$ & $\mathrm{F}$ \\
\hline San Luis Rey River/CMET & Pilgrim Creek / PS05 / MCBCP & 5.04 & BPST: PUPU Mdb & $1 \mathrm{yr}$ & M \\
\hline San Luis Rey River/DDOL & Pueblitos Canyon / PU03 / MCBCP & 4.83 & BPST: BWST Mdb & $1 \mathrm{yr}$ & M \\
\hline San Luis Rey River/FAQU & Ysidora Basin / YB63 / MCBCP & 3.43 & PUWH: YEBK Mdb & $1 \mathrm{yr}$ & M \\
\hline San Luis Rey River/CSNE & Middle San Luis Rey River / MSL113 & 2.61 & DBWH: BPST Mdb & $1 \mathrm{yr}$ & $\mathrm{F}$ \\
\hline
\end{tabular}




\title{
Appendix 6. Between-year Movement of Least Bell's Vireos banded as Juveniles in $\mathbf{2 0 1 9}$ at the San Luis Flood Risk Program Area; redetected in 2020
}

The table in this appendix lists all Least Bell's Vireos that were banded in 2019 as nestlings in the Project Area that were detected as breeding adults in 2020. The table includes the location of the 2019 natal territory and 2020 territory, dispersal distance, band combo, and sex of the bird.

Table 6.1. Between-year movement of Least Bell's Vireos banded as juveniles in 2019 at the San Luis Flood Risk Program Area; redetected in 2020 .

\begin{abstract}
[Abbreviations: MCBCP, Marine Corps Base Camp Pendleton. Band colors: BKYE, plastic black-yellow split; BPST, plastic black-pink striped; BWST, plastic blue-white striped; DBDP, plastic dark blue-dark pink split; DBWH, plastic dark blue-white split; DPDB, dark pink-dark blue split; DPDP, plastic dark pink; DPWH, plastic dark pink-white split; Mdb, dark blue numbered federal band; PUPU, plastic purple; pupu, metal purple; PUWH, plastic purple-white split; PUYE, plastic purple-yellow split; WHWH, plastic white; YEBK, plastic yellow-black split; YEPU, plastic yellow-purple split. Sex: M, male; F, female; km, kilometer]
\end{abstract}

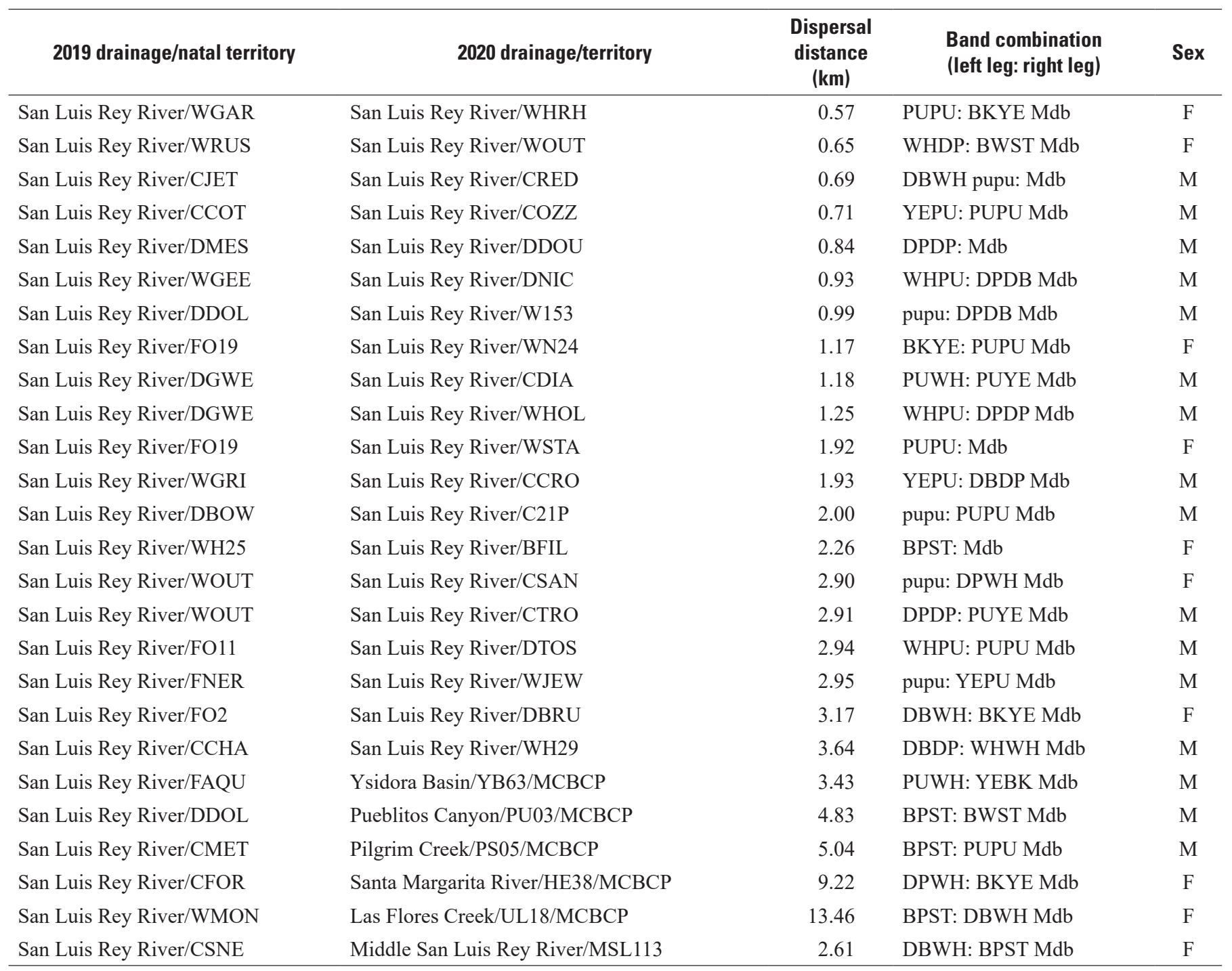




\section{Appendix 7. Between-year Movement of Adult Least Bell's Vireos at the San Luis Rey Flood Risk Management Project Area, 2020}

The table in this appendix lists all banded vireos identified in 2020 with their previous known territories, band combination, distance moved, age, and sex of the bird.

Table 7.1. Between-year movement of adult Least Bell's Vireos at the San Luis Rey Flood Risk Management Project Area, 2020.

[Drainage Codes: SLR, San Luis Rey River. Band colors: BKBK, plastic black; BKLP, plastic black-light pink split; BKYE, plastic black-yellow split; BPST, plastic black-pink striped; BWST, plastic blue-white striped; BYST, plastic black-yellow striped; DBDP, plastic dark blue-dark pink split; DBWH, plastic dark blue-white split; DPDB, plastic dark-pink dark-blue split; DPDP, plastic dark pink; DPWH, plastic dark pink-white split; gogo, metal gold; LPBK, plastic light pink-black split; Mdb, dark blue numbered federal band; PUPU, plastic purple; pupu, metal purple; PUWH, plastic purple-white split; PUYE, plastic purple-yellow split; WHDB, plastic white-dark blue split; WHDP, plastic white-dark pink split; WHPU, plastic white-purple split; WHWH, plastic white; YEBK, plastic yellow-black split; YEPU, plastic yellow-purple split; YEYE, plastic yellow. Age: Exact age determined from uniquely numbered metal band observed during recapture; estimated age applies to an unbanded bird captured as an after-hatch-year. Sex: M, male; F, female; 一, undetermined sex; Abbreviations: km, kilometer yrs, years; $\geq$, greater than or equal to]

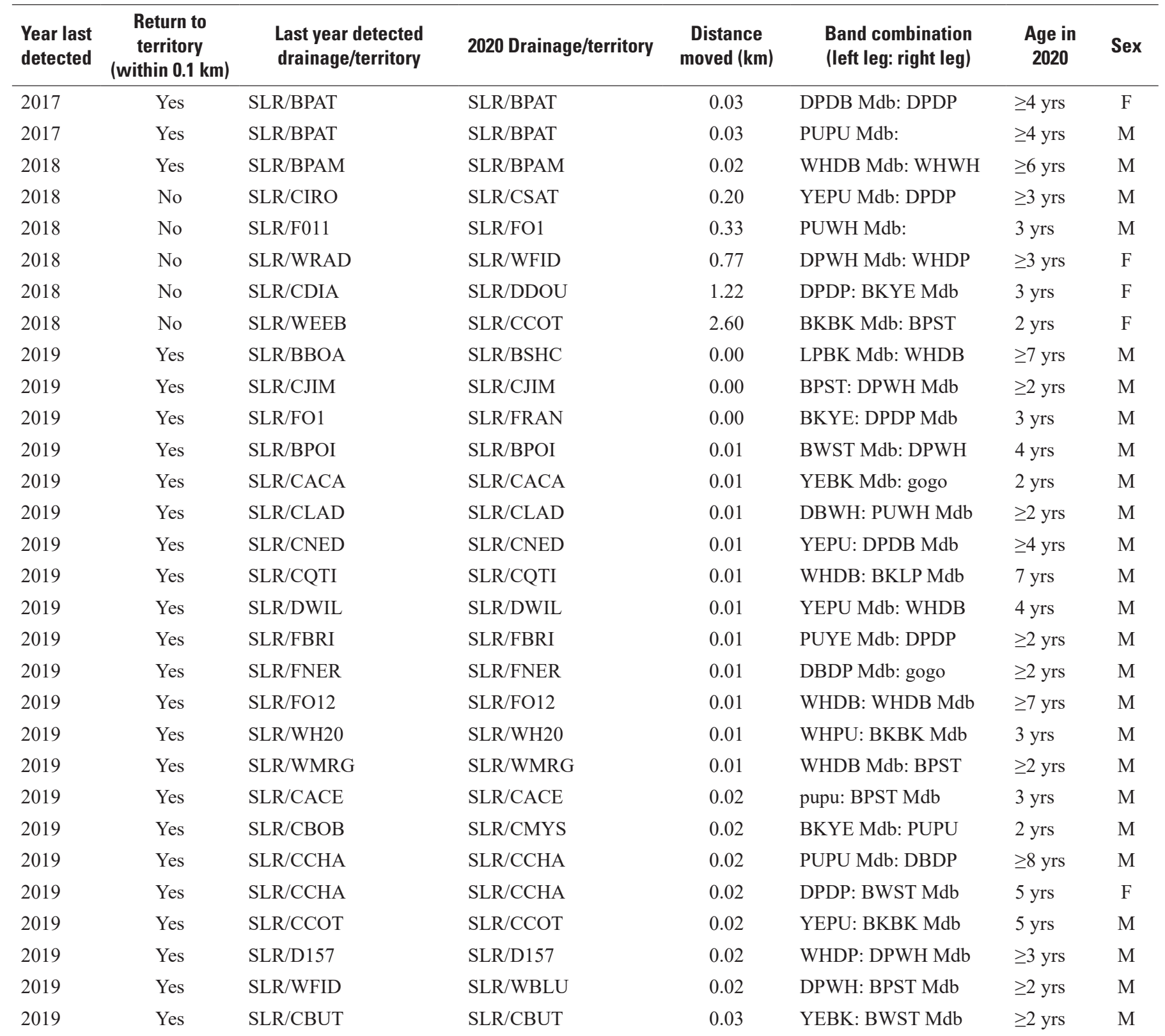


Table 7.1. Between-year movement of adult Least Bell's Vireos at the San Luis Rey Flood Risk Management Project Area, 2020.Continued

[Drainage Codes: SLR, San Luis Rey River. Band colors: BKBK, plastic black; BKLP, plastic black-light pink split; BKYE, plastic black-yellow split; BPST, plastic black-pink striped; BWST, plastic blue-white striped; BYST, plastic black-yellow striped; DBDP, plastic dark blue-dark pink split; DBWH, plastic dark blue-white split; DPDB, plastic dark-pink dark-blue split; DPDP, plastic dark pink; DPWH, plastic dark pink-white split; gogo, metal gold; LPBK, plastic light pink-black split; Mdb, dark blue numbered federal band; PUPU, plastic purple; pupu, metal purple; PUWH, plastic purple-white split; PUYE, plastic purple-yellow split; WHDB, plastic white-dark blue split; WHDP, plastic white-dark pink split; WHPU, plastic white-purple split; WHWH, plastic white; YEBK, plastic yellow-black split; YEPU, plastic yellow-purple split; YEYE, plastic yellow. Age: Exact age determined from uniquely numbered metal band observed during recapture; estimated age applies to an unbanded bird captured as an after-hatch-year. Sex: M, male; F, female; -, undetermined sex; Abbreviations: $\mathrm{km}$, kilometer yrs, years; $\geq$, greater than or equal to]

\begin{tabular}{|c|c|c|c|c|c|c|c|}
\hline $\begin{array}{l}\text { Year last } \\
\text { detected }\end{array}$ & $\begin{array}{c}\text { Return to } \\
\text { territory } \\
\text { (within } 0.1 \text { km) }\end{array}$ & $\begin{array}{l}\text { Last year detected } \\
\text { drainage/territory }\end{array}$ & 2020 Drainage/territory & $\begin{array}{c}\text { Distance } \\
\text { moved (km) }\end{array}$ & $\begin{array}{l}\text { Band combination } \\
\text { (left leg: right leg) }\end{array}$ & $\begin{array}{c}\text { Age in } \\
2020\end{array}$ & Sex \\
\hline 2019 & Yes & SLR/CSTA & SLR/CSTA & 0.03 & DPDB Mdb: PUWH & $\geq 3 \mathrm{yrs}$ & $\mathrm{M}$ \\
\hline 2019 & Yes & SLR/DDOL & SLR/DDOL & 0.03 & WHDP Mdb: PUWH & $\geq 3 \mathrm{yrs}$ & $\mathrm{M}$ \\
\hline 2019 & Yes & SLR/DMAD & SLR/DMAD & 0.03 & PUWH: BKYE Mdb & $\geq 2 \mathrm{yrs}$ & $\mathrm{M}$ \\
\hline 2019 & Yes & SLR/FO10 & SLR/FO10 & 0.03 & DBWH: WHDB Mdb & $\geq 2 \mathrm{yrs}$ & $\mathrm{M}$ \\
\hline 2019 & Yes & SLR/WDID & SLR/WDID & 0.03 & BKBK Mdb: PUYE & $\geq 3 \mathrm{yrs}$ & $\mathrm{M}$ \\
\hline 2019 & Yes & SLR/WDOB & SLR/WDOB & 0.03 & DPWH Mdb: YEBK & $\geq 2 \mathrm{yrs}$ & $\mathrm{M}$ \\
\hline 2019 & Yes & SLR/WMAN & SLR/WMAN & 0.03 & : PUYE & $\geq 3 \mathrm{yrs}$ & $\mathrm{M}$ \\
\hline 2019 & Yes & SLR/DGWE & SLR/DGWE & 0.04 & PUWH: DBDP Mdb & 3 yrs & $\mathrm{M}$ \\
\hline 2019 & Yes & SLR/BPEA & SLR/BPEA & 0.06 & DBDP: PUYE Mdb & $3 \mathrm{yrs}$ & M \\
\hline 2019 & Yes & $\mathrm{SLR} / \mathrm{CSCH}$ & SLR/CJET & 0.06 & : PUPU Mdb & 4 yrs & M \\
\hline 2019 & Yes & SLR/FO2 & $\mathrm{SLR} / \mathrm{FO} 2$ & 0.06 & Mdb: BKYE gogo & $\geq 2 \mathrm{yrs}$ & M \\
\hline 2019 & Yes & SLR/FO40 & SLR/FMAV & 0.06 & BKYE: PUWH Mdb & 3 yrs & $\mathrm{M}$ \\
\hline 2019 & Yes & SLR/CFLO & SLR/CHOO & 0.07 & WHPU Mdb: DPDP & $\geq 3 \mathrm{yrs}$ & $\mathrm{M}$ \\
\hline 2019 & Yes & SLR/BKEN & SLR/BTOK & 0.08 & LPBK: BKLP Mdb & $\geq 6 \mathrm{yrs}$ & M \\
\hline 2019 & Yes & SLR/CDIA & SLR/CPAN & 0.08 & PUWH Mdb: DBDP & $\geq 2 \mathrm{yrs}$ & M \\
\hline 2019 & Yes & SLR/CACE & $\mathrm{SLR} / \mathrm{CSCH}$ & 0.09 & BYST Mdb: WHDP & 4 yrs & $\mathrm{F}$ \\
\hline 2019 & Yes & SLR/WGEE & SLR/WSTA & 0.09 & DPDP: YEBK Mdb & $\geq 2 \mathrm{yrs}$ & M \\
\hline 2019 & No & SLR/CSOC & SLR/CWIL & 0.13 & DBDP Mdb: PUWH & $\geq 2 \mathrm{yrs}$ & M \\
\hline 2019 & No & SLR/WH25 & SLR/WH21 & 0.13 & DPDB Mdb: WHPU & 2 yrs & M \\
\hline 2019 & No & SLR/WRUS & SLR/WBAN & 0.13 & BKYE Mdb: gogo & $\geq 2 \mathrm{yrs}$ & M \\
\hline 2019 & No & SLR/BSCR & SLR/CKES & 0.14 & PUYE: WHDB Mdb & $\geq 2 \mathrm{yrs}$ & M \\
\hline 2019 & No & SLR/CJET & SLR/CLAD & 0.14 & BYST: BKBK Mdb & $9 \mathrm{yrs}$ & $\mathrm{F}$ \\
\hline 2019 & No & SLR/FO4 & SLR/FO6 & 0.14 & DBWH Mdb: WHDP & $\geq 3 \mathrm{yrs}$ & M \\
\hline 2019 & No & SLR/BHAN & SLR/BSAL & 0.17 & WHWH Mdb: BKBK & $\geq 8 \mathrm{yrs}$ & M \\
\hline 2019 & No & SLR/CPUR & SLR/CSAT & 0.18 & WHDP Mdb: YEBK & 4 yrs & $\mathrm{F}$ \\
\hline 2019 & No & SLR/CDIS & SLR/CSAN & 0.26 & BPST: WHDB Mdb & $\geq 2 \mathrm{yrs}$ & M \\
\hline
\end{tabular}


Table 7.1. Between-year movement of adult Least Bell's Vireos at the San Luis Rey Flood Risk Management Project Area, 2020.— Continued

[Drainage Codes: SLR, San Luis Rey River. Band colors: BKBK, plastic black; BKLP, plastic black-light pink split; BKYE, plastic black-yellow split; BPST, plastic black-pink striped; BWST, plastic blue-white striped; BYST, plastic black-yellow striped; DBDP, plastic dark blue-dark pink split; DBWH, plastic dark blue-white split; DPDB, plastic dark-pink dark-blue split; DPDP, plastic dark pink; DPWH, plastic dark pink-white split; gogo, metal gold; LPBK, plastic light pink-black split; Mdb, dark blue numbered federal band; PUPU, plastic purple; pupu, metal purple; PUWH, plastic purple-white split; PUYE, plastic purple-yellow split; WHDB, plastic white-dark blue split; WHDP, plastic white-dark pink split; WHPU, plastic white-purple split; WHWH, plastic white; YEBK, plastic yellow-black split; YEPU, plastic yellow-purple split; YEYE, plastic yellow. Age: Exact age determined from uniquely numbered metal band observed during recapture; estimated age applies to an unbanded bird captured as an after-hatch-year. Sex: M, male; F, female; -, undetermined sex; Abbreviations: km, kilometer yrs, years; $\geq$, greater than or equal to]

\begin{tabular}{|c|c|c|c|c|c|c|c|}
\hline $\begin{array}{l}\text { Year last } \\
\text { detected }\end{array}$ & $\begin{array}{c}\text { Return to } \\
\text { territory } \\
\text { (within } 0.1 \text { km) }\end{array}$ & $\begin{array}{l}\text { Last year detected } \\
\text { drainage/territory }\end{array}$ & 2020 Drainage/territory & $\begin{array}{c}\text { Distance } \\
\text { moved (km) }\end{array}$ & $\begin{array}{l}\text { Band combination } \\
\text { (left leg: right leg) }\end{array}$ & $\begin{array}{c}\text { Age in } \\
2020\end{array}$ & Sex \\
\hline 2019 & No & SLR/WFID & SLR/WBAN & 0.41 & YEYE: WHDB Mdb & $3 \mathrm{yrs}$ & $\mathrm{F}$ \\
\hline 2019 & No & SLR/WH200 & SLR/DMES & 0.65 & WHDB Mdb: DBDP & $2 \mathrm{yrs}$ & M \\
\hline 2019 & No & SLR/CFOR & SLR/CPAT & 0.83 & PUWH Mdb: YEBK & $\geq 2 \mathrm{yrs}$ & $\mathrm{M}$ \\
\hline 2019 & No & SLR/CJAS & SLR/DDOL & 2.44 & BPST Mdb: PUWH & $2 \mathrm{yrs}$ & $\mathrm{F}$ \\
\hline
\end{tabular}




\section{Appendix 8. Locations of Vegetation Transects, Nest-Centered Vegetation Plots, and Vegetation Treatments at the San Luis Rey Flood Risk Management Project Area, 2020}

In this appendix, maps show the location of all vegetation sampling transects, nest-centered vegetation plots, and vegetation treatments in the Project Area.

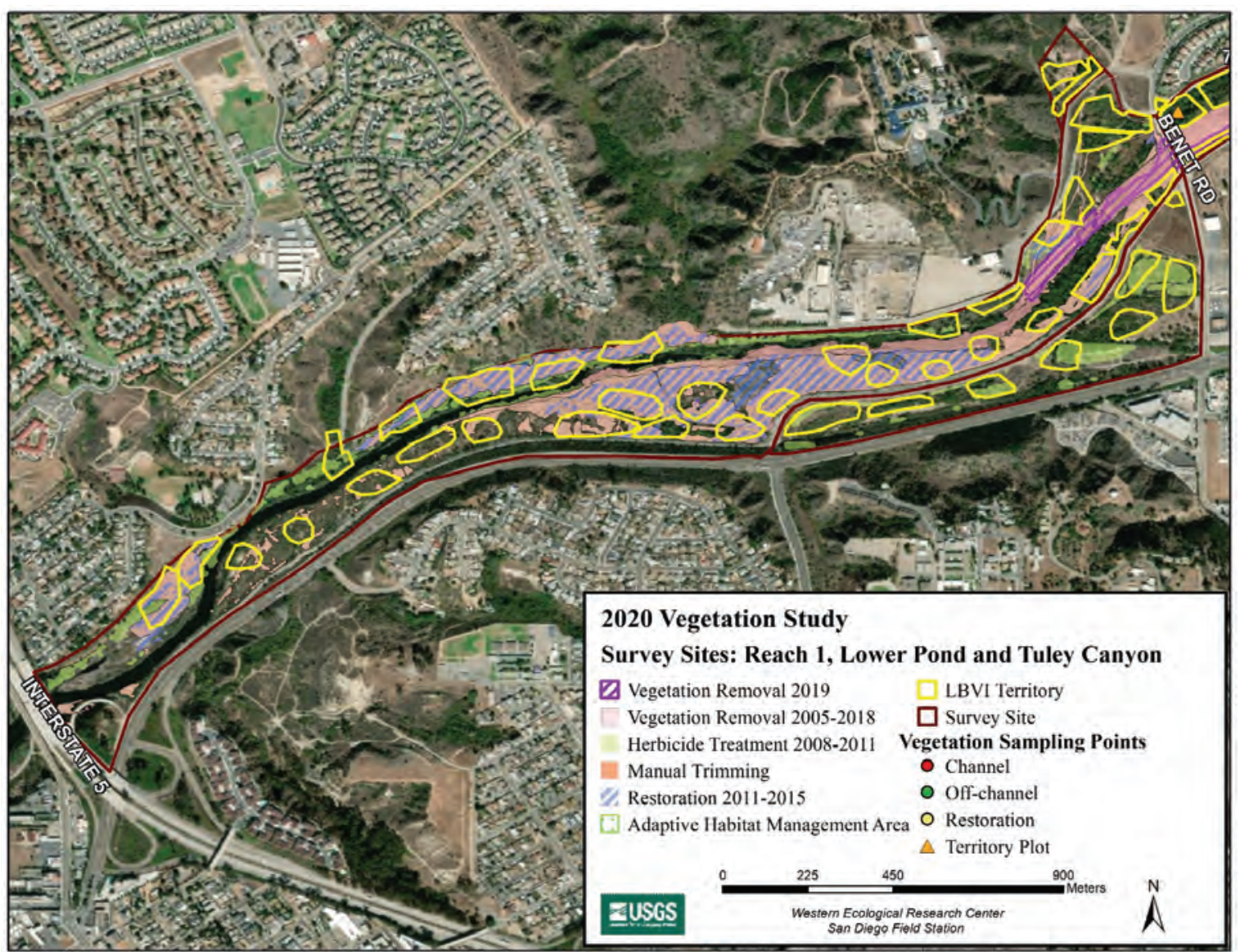

Map image is the intellectual property of Esri and is used herein under license.

Copyright (c) 2020 Esri and its licensors. All rights reserved.

Figure 8.1. Locations of vegetation treatments in Reach 1, Lower Pond, and Tuley Canyon survey sites at the San Luis Rey Flood Risk Management Project Area, California, in 2020. 


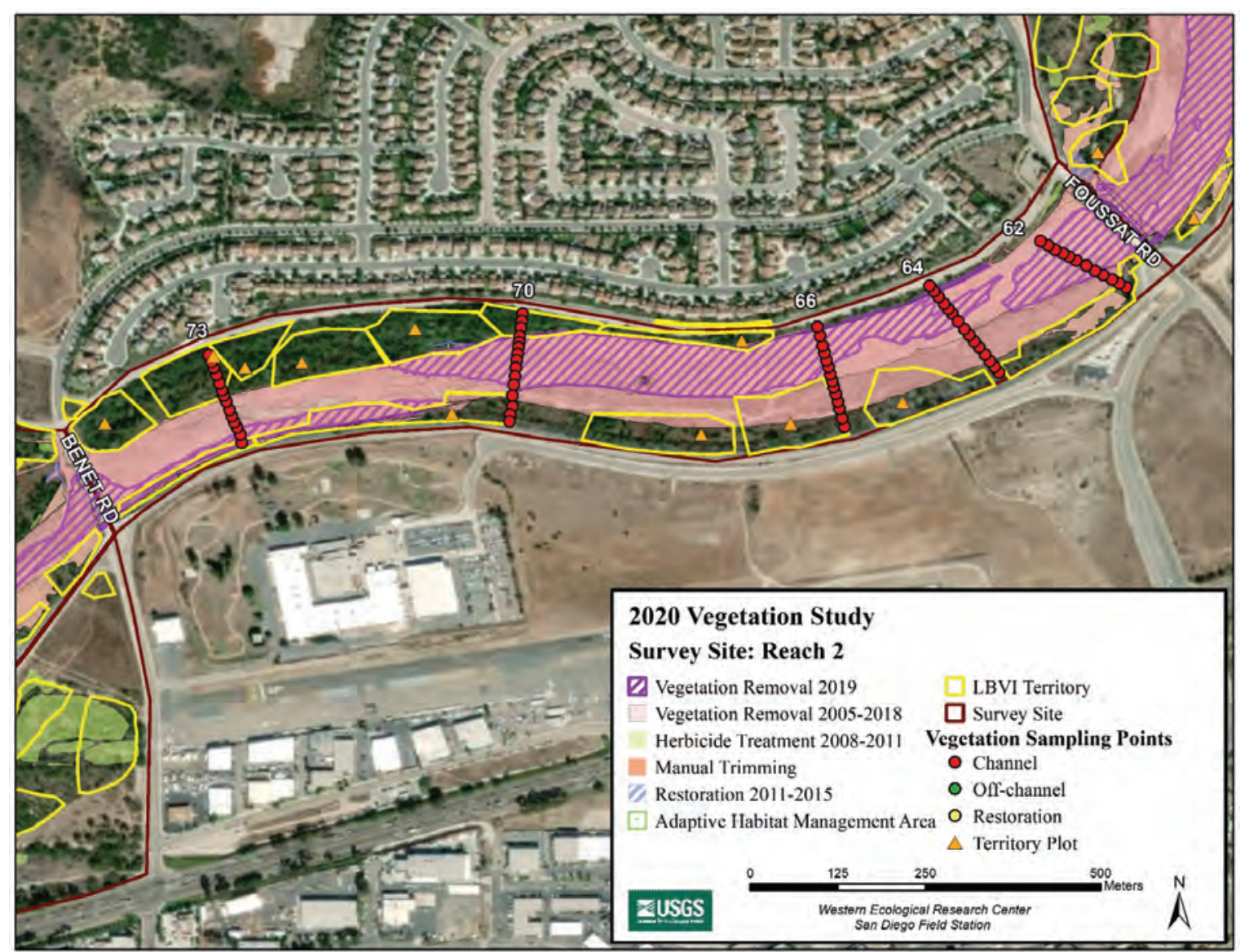

Map image is the intellectual property of Esri and is used herein under license. Copyright (c) 2020 Esri and its licensors. All rights reserved.

Figure 8.2. Locations of vegetation transects and territory plots in the Reach 2 survey site at the San Luis Rey Flood Risk Management Project Area, California, in 2020. 


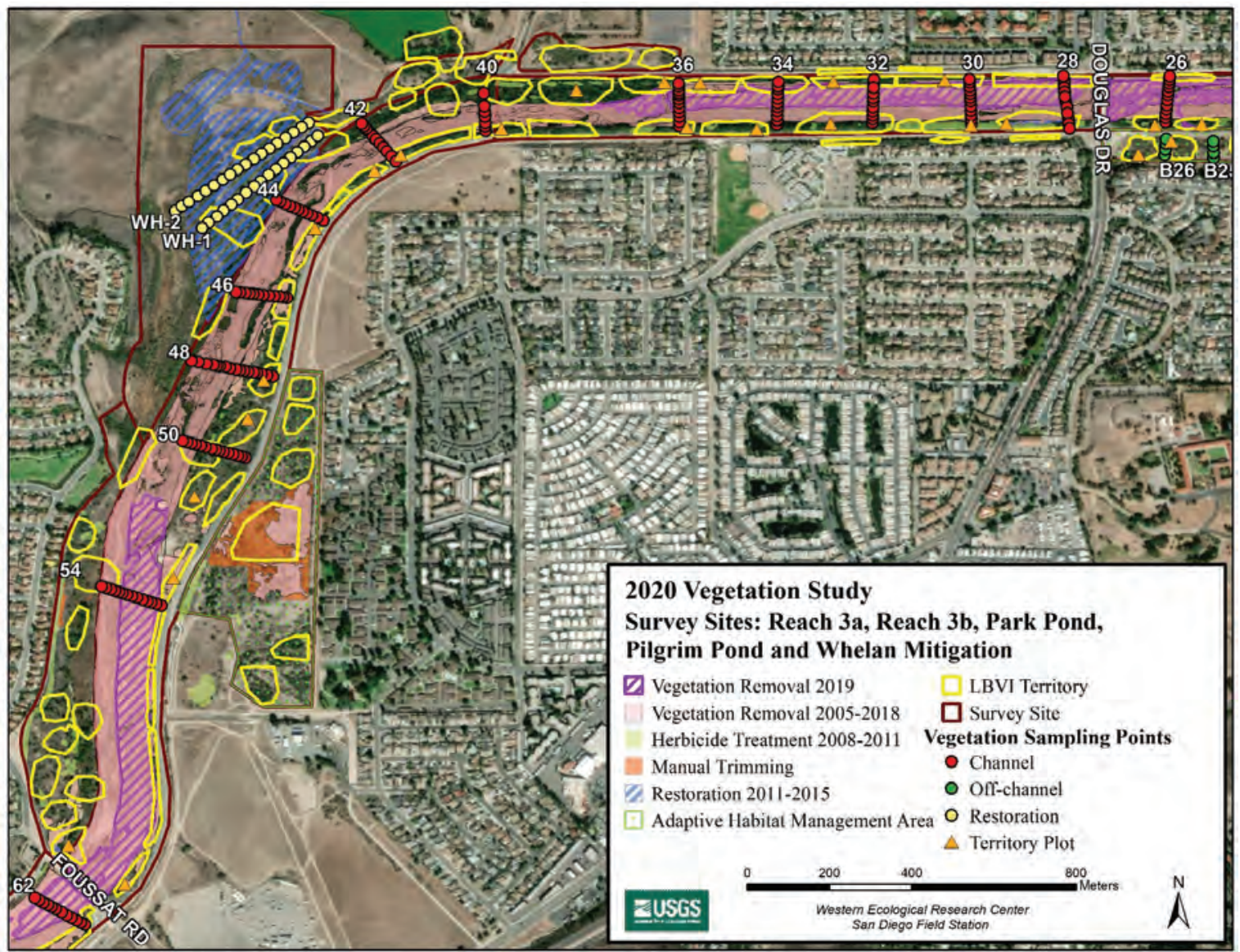

Map image is the intellectual property of Esri and is used herein under license.

Copyright (C) 2020 Esri and its licensors. All rights reserved.

Figure 8.3. Locations of vegetation transects and territory plots in the Reach 3a, Reach $3 b$, Park Pond, Pilgrim Pond, and Whelan Mitigation survey sites at the San Luis Rey Flood Risk Management Project Area, California, in 2020. 


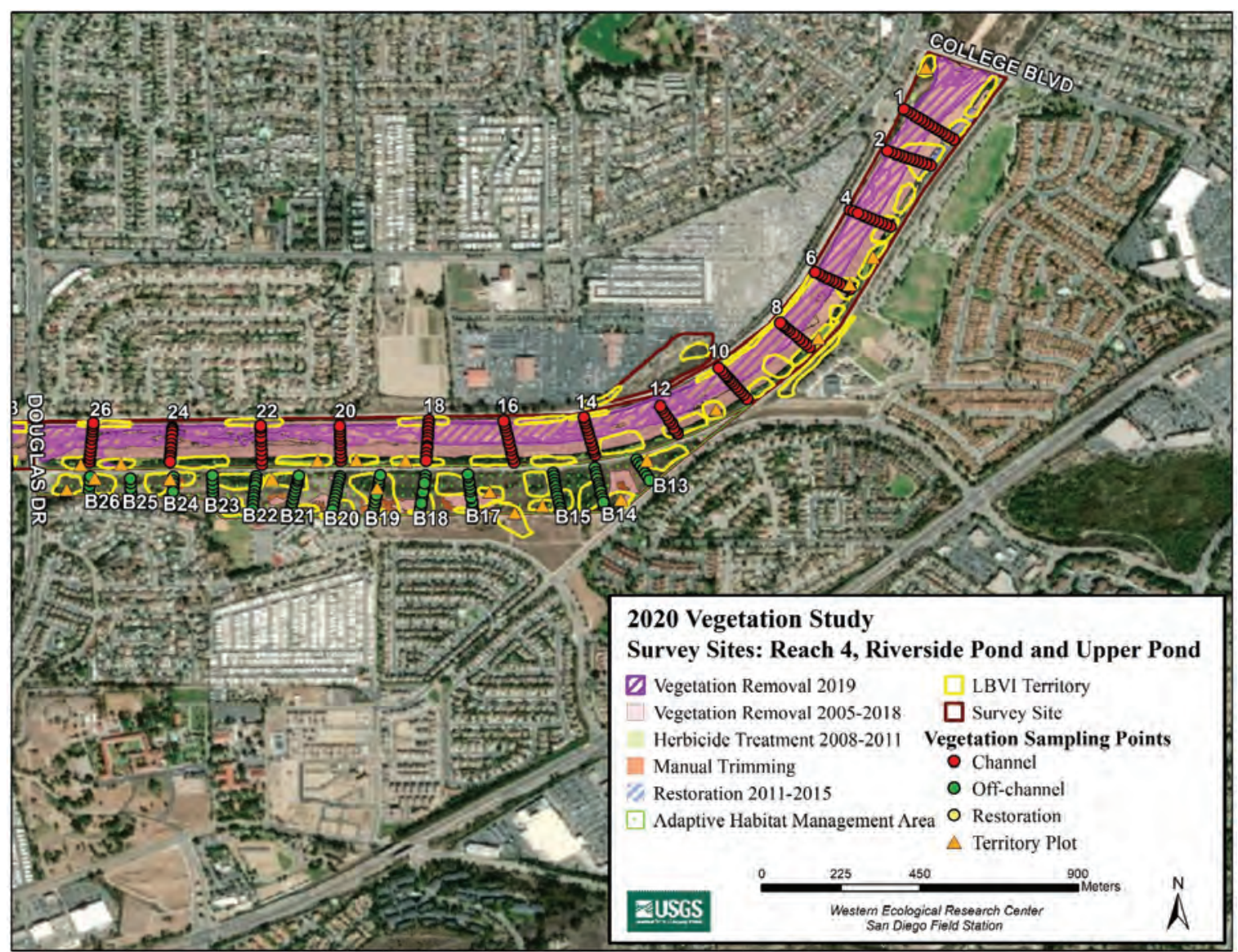

Map image is the intellectual property of Esri and is used herein under license. Copyright (c) 2020 Esri and its licensors. All rights reserved.

Figure 8.4. Locations of vegetation transects and territory plots in Reach 4, Riverside Pond, and Upper Pond survey sites at the San Luis Rey Flood Risk Management Project Area, California, in 2020. 


\section{Appendix 9. Global Positioning System Coordinates (Decimal Degrees; World Geographic System of 1984) for the Start and End Points (Quadrat) of Each Vegetation Transect Sampled at the San Luis Rey Flood Risk Management Project Area in 2006-20}

The table in this appendix lists the location and the Global Positioning System coordinates for the start and end point for all vegetation transects in the Project Area.

Table 9.1. Global Positioning System coordinates (Decimal Degrees; WGS 84) for the start and end points (Quadrat) of each vegetation transect sampled at the San Luis Rey Flood Risk Management Project Area in 2006-20.

[Quad indicates the distance in meters along a transect. Abbreviations: ID, identification; =, equals; —, not applicable]

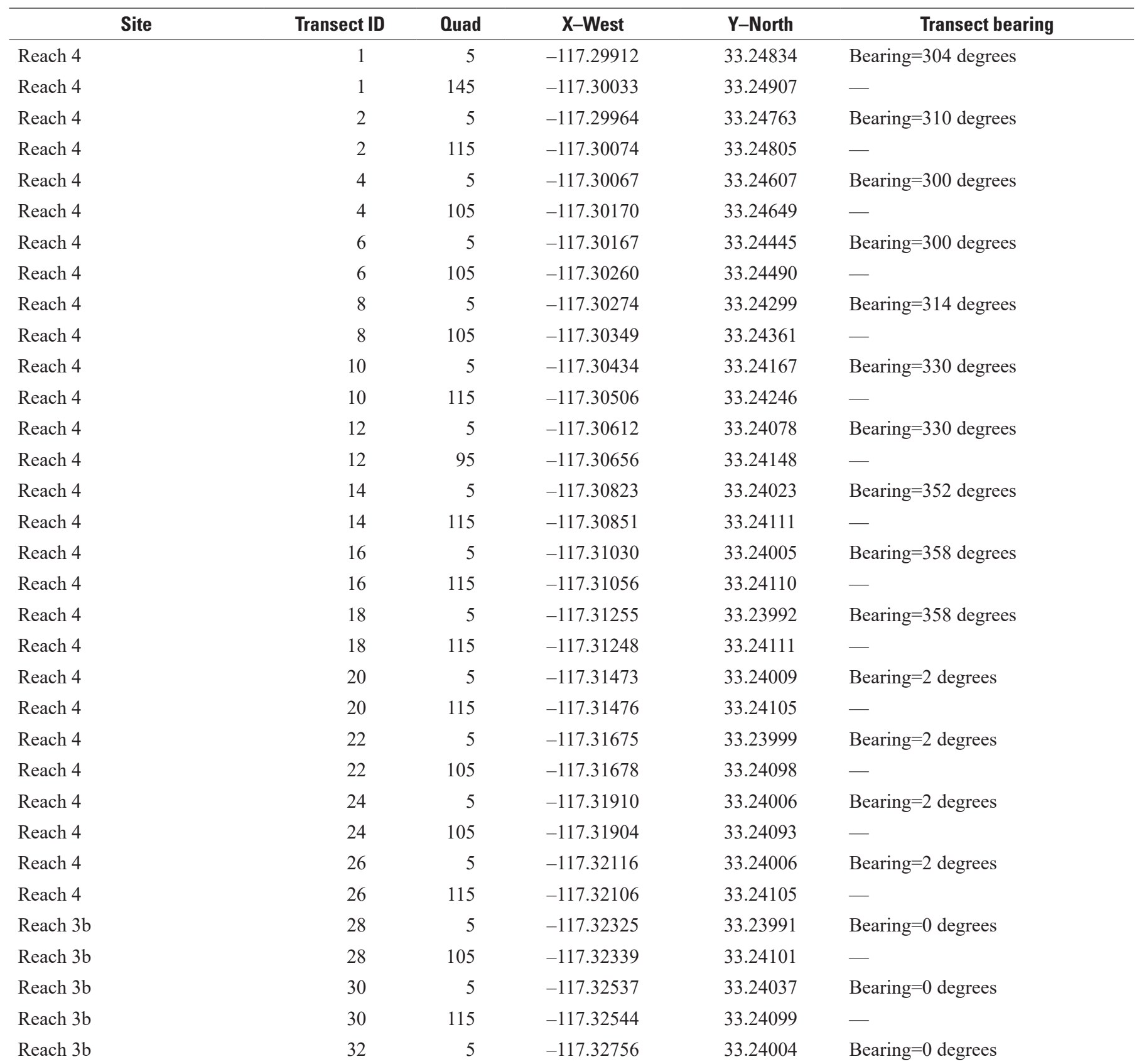


Table 9.1. Global Positioning System coordinates (Decimal Degrees; WGS 84) for the start and end points (Quadrat) of each vegetation transect sampled at the San Luis Rey Flood Risk Management Project Area in 2006-20.-Continued

[Quad indicates the distance in meters along a transect. Abbreviations: ID, identification; =, equals; - , not applicable]

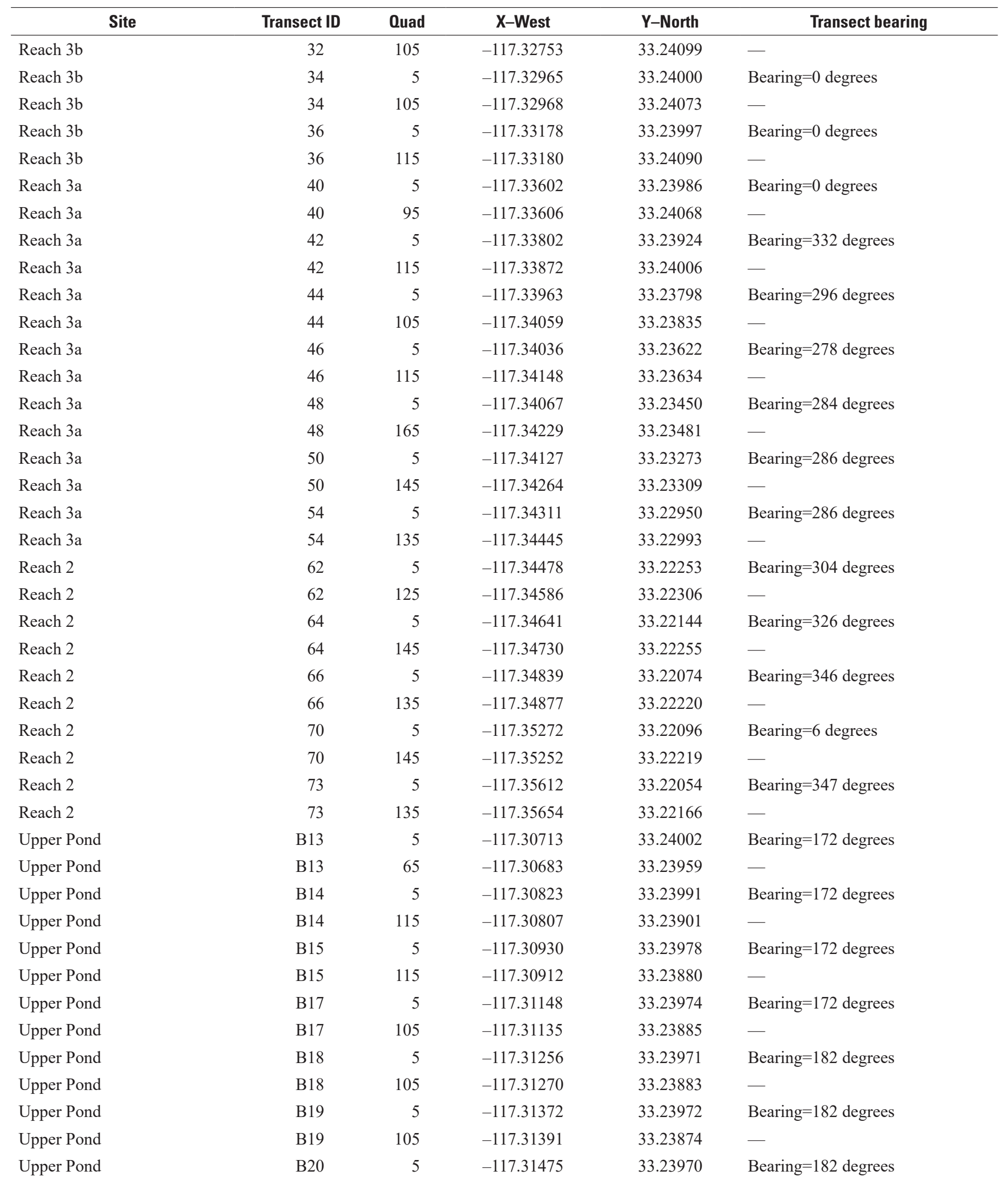


Table 9.1. Global Positioning System coordinates (Decimal Degrees; WGS 84) for the start and end points (Quadrat) of each vegetation transect sampled at the San Luis Rey Flood Risk Management Project Area in 2006-20.—Continued

[Quad indicates the distance in meters along a transect. Abbreviations: ID, identification; =, equals; —, not applicable]

\begin{tabular}{lcrccl}
\hline \multicolumn{1}{c}{ Site } & Transect ID & Quad & X-West & Y-North & \multicolumn{1}{c}{ Transect bearing } \\
\hline Upper Pond & B20 & 105 & -117.31495 & 33.23881 & - \\
Upper Pond & B21 & 5 & -117.31580 & 33.23972 & Bearing=182 degrees \\
Upper Pond & B21 & 105 & -117.31602 & 33.23880 & - \\
Upper Pond & B22 & 5 & -117.31689 & 33.23969 & Bearing=182 degrees \\
Upper Pond & B22 & 95 & -117.31699 & 33.23885 & - \\
Upper Pond & B23 & 5 & -117.31802 & 33.23968 & Bearing=182 degrees \\
Upper Pond & B23 & 55 & -117.31800 & 33.23920 & - \\
Upper Pond & B24 & 5 & -117.31901 & 33.23964 & Bearing=182 degrees \\
Upper Pond & B24 & 45 & -117.31902 & 33.23930 & - \\
Upper Pond & B25 & 5 & -117.32011 & 33.23963 & Bearing=182 degrees \\
Upper Pond & B25 & 35 & -117.32010 & 33.23927 & - \\
Upper Pond & B26 & 5 & -117.32110 & 33.23955 & Bearing=182 degrees \\
Upper Pond & B26 & 35 & -117.32118 & 33.23925 & - \\
Whelan Mitigation & WH-1 & 5 & -117.33969 & 33.23975 & Bearing=345 degrees \\
Whelan Mitigation & WH-1 & 325 & -117.34222 & 33.23774 & - \\
Whelan Mitigation & WH-2 & 5 & -117.33989 & 33.24004 & Bearing=345 degrees \\
Whelan Mitigation & WH-2 & 345 & -117.34281 & 33.23811 & - \\
\hline
\end{tabular}



For more information concerning the research in this report, contact the

Director, Western Ecological Research Center

U.S. Geological Survey

3020 State University Drive East

Sacramento, California 95819

https://www.usgs.gov/centers/werc

Publishing support provided by the U.S. Geological Survey

Science Publishing Network, Sacramento Publishing Service Center 


\section{$\frac{1}{3}$}

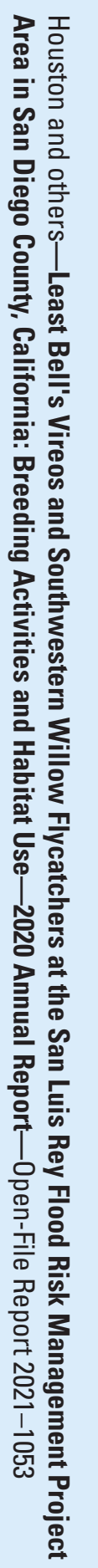

